\title{
Youth Development Performance Management in Municipalities: \\ A Nkangala District Municipality Case Study
}

\begin{abstract}
by
Steven Piet Ngubeni

Thesis submitted in partial fulfilment of the requirements for the degree of Master in Public Administration at the University of Stellenbosch
\end{abstract}

Supervisor : Professor APJ Burger

March 2013 


\section{DECLARATION}

By submitting this research report in an electronic form, I, Steven Ngubeni, declare that is my own unaided work. The sources used in the report have been acknowledged and properly referenced. This study in whole or part, has never been submitted to any other university for academic examination.

Steven Piet Ngubeni

Date

$\square$

$\square$

$\square$

$\square$

0

(1)

$\square$

$\square$

$\square$

(]

$\square$

○

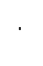

$\square$

$\square$

$\square$

$\square$

$\square$

○

$\square$

$\square$

$\square$

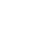

$\square$

$\square$

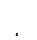

○

\&RS U] KW]

\$ QUل KWUHMHUHG 


\section{AKNOWLEDGEMENTS}

First of all let me thank the almighty GOD for the plan he has for me. He is in total control of my achievements in life.

Special thanks are dedicated to my family, particularly my wife, for your unwavering support. To my late father, a tractor driver who taught me how to stand on my own. To my mother, the most phenomenal woman who encouraged me to go to school even when she was illiterate. This is the woman who taught me how to endure even when peer pressure seemed insurmountable. I owe my success to your strength, wisdom and support.

I wish to also express my sincere gratitude to the University of Stellenbosch School of Public Leadership and particularly Professor APJ Burger, for his guidance and patience. To Ms Rihana Moore for all the administrative assistance she provided to me as student.

Thanks to Dr Edwin Hees, Dr Rangarirai Musvoto, my brother, and Ms Amuzweni Ngoma for proofreading and editing my work. You continue to inspire me to learn more about the Queen's English.

I also wish to thank the youth development experts in Nkangala District and its Municipalities for allowing time to interview them and to join the focus group discussions. Your experience is invaluable.

Finally, to my colleagues at the National Youth Development Agency, working with you has invoked in me even greater passion for youth development. Your insights, criticisms and contributions inspire my intellect. To Tania and Dimakatso for your help with typing, thank you. 


\section{ABSTRACT}

Like in many developing countries, youth development in South Africa is advancing towards becoming the central focus of government. The population figures illustrate a demographic dividend, or youth bulge as others would want to call it. A more pragmatic and aggressive approach to youth development for South Africa has never been more urgent than now. Municipalities by design are at the grassroots and the gateway for providing direct development interventions to the masses of the peoples of South Africa. Most of the municipalities in the country have started to take up this responsibility. There is, however, evidence that success in implementing youth development programmes is limited, owing mainly to the lack of performance management application at the local government level.

This study is intended to explore a research problem defined as follows: "The absence of a tailor-made performance management for youth development leads to limited or no achievement of the set targets for youth development."

The study is started by exploring the literature on both the underlying areas of the study: youth development and performance management. Though youth development is a fairly new area, there has been progress in defining and conceptualizing both performance management and youth development in South Africa. Youth and youth development are defined respectively as young people between 14 and 35 years of age, and deliberate interventions to enable the youth to participate in the socioeconomic wellbeing of the country and the world. Performance management is further defined as the process towards ensuring there is a concerted effort in the implementation of the predetermined plans.

The researcher opted for the case study approach, using Nkangala District Municipality (NDM) as the case to explore the extent to which municipalities apply the prescripts and principles of performance management to the youth development programmes. The study sought to establish whether municipalities have performance management frameworks and systems, whether youth development matters are included and whether there are specific youth development performance measures in place. The literature shows that there is extensive work done on the area of performance management in local government in South Africa. The legislation compels all municipalities to have performance management systems and frameworks in place and adopted by the councils. The document review shows that in Nkangala District Municipality there is still a need to trickle down the application of the systems and framework. There is a need to ensure that youth development is included in the performance management process.

Evidence from the study shows that there are still gaps to be addressed in as far as the district is concerned. Their application of the performance management framework and systems still needs to be cascaded to all staff members; the application must still be applied to youth development programme and youth development units. There is a need to align municipal planning with youth development. Youth participation still remains a challenge throughout the process of planning, implementation and reporting. 
Municipalities are suffering from attitudes that suggest that youths are simply recipients of hand-out products and services. Finally, the study suggest a Youth Development Performance Management Framework which will also integrate youth participation, monitoring and evaluation. 


\section{OPSOMMING}

Soos in baie ontwikkelende lande neig jeugontwikkeling in Suid-Afrika daarna om die sentrale fokus van die regering te word. Die bevolkingsyfers illustreer 'n demografiese dividend of jeug uitstulping ("youth bulge"), soos wat daarna verwys word. ' $\mathrm{n}$ Meer pragmatiese en aggresiewe benadering tot jeugontwikkeling was nog nooit meer dringend vir Suid-Afrika as juis tans nie. Munisipaliteite, deur ontwerp, is op voetsoolvlak en die poort vir die verskaffing van direkte ontwikkelingsingrypings vir die meerderheid van mense in Suid-Afrika. Meeste van die munisipaliteite in die land het begin om hierdie verantwoordelikheid op te neem. Daar is egter bewyse dat sukses in die implementering van jeugontwikkelingsprogramme beperk is, veral as gevolg van die gebrek aan die aanwending van prestasiebestuur op die vlak van plaaslike regering.

Hierdie studie is bedoel om die navorsingsprobleem gedefinieer as: "die afwesigheid van 'n pasgemaakte prestasiebestuurstelsel vir jeugontwikkeling lei tot beperkte of gebrekkige bereiking van die gestelde teikens vir jeugontwikkeling" Te verken.

Die studie begin deur die literatuur te ondersoek op beide die onderliggende gebiede van die studie, jeugontwikkeling en prestasiebestuur. Hoewel jeugontwikkeling ' $n$ redelik nuwe gebied is, is daar vordering in die definiëring en konseptualisering van beide prestasiebestuur en jeugontwikkeling in SuidAfrika. Jeug en jeugontwikkeling word gedefinieer as jong mense tussen 14 en 35 jaar oud en doelbewuste intervensies om die jeug in staat te stel om deel te neem aan die sosio-ekonomiese welstand van die land en die wêreld. Prestasiebestuur word gedefinieer as die proses om te verseker dat daar 'n gesamentlike poging is vir die implementering van die voorafbepaalde planne.

Die navorser het besluit op 'n gevallestudie benadering, deur gebruik te maak van die Nkangala Distriksmunisipaliteit (NDM) om die mate waarin munisipaliteite die voorskrifte en beginsels van prestasiebestuur op die jeugontwikkelingsprogramme toepas te verken. Die studie poog om vas te stel of munisipaliteite prestasiebestuursraamwerke en stelsels het, of jeugontwikkelingsaangeleenthede ingesluit is en of daar spesifieke jeugontwikkeling prestasiemaatreëls in plek is. Literatuur toon dat daar vitgebreide werk gedoen is op die gebied van prestasiebestuur in plaaslike regering in Suid-Afrika. Die wetgewing verplig alle munisipaliteite om prestasiebestuurstelsels en raamwerke in plek te hê en goedgekeur deur die rade. Die dokumentêre hersiening toon dat daar in die Nkangala Distriksmunisipaliteit steeds ' $\mathrm{n}$ behoefte daaraan is om die toepassing van die stelsels en raamwerk te laat deursyfer. Daar is 'n behoefte om te verseker dat jeugontwikkeling ingesluit word in die prestasiebestuursproses.

Bewyse uit die studie toon dat daar steeds gapings is om aan te spreek met betrekking tot die distrik. Die aanwending van die prestasiebestuursraamwerk en stelsels moet nog afgewentel word na alle personeellede. Die aanwending moet nog van toepassing gemaak word op jeugontwikkeling en jeugontwikkelingseenhede. Daar is ' $n$ behoefte om munisipale beplanning in 
lyn te bring met jeugontwikkeling. Jeug deelname dwarsdeur die proses van beplanning, implementering en rapportering bly steeds 'n vitdaging. Munisipaliteite ly onder gesindhede wat daarop dui dat die jeug eenvoudig ontvangers is van produkte en dienste. Die studie stel ten slotte 'n jeugontwikkeling prestasiebestuursraamwerk voor wat ook jeug deelname, monitering en evaluering sal integreer. 


\section{LIST OF ABBREVIATIONS}

$\begin{array}{lll}\text { ANC } & - & \text { African National Congress } \\ \text { ANC YL } & - & \text { African National Congress Youth League } \\ \text { AU } & - & \text { African Union } \\ \text { BSC } & - & \text { Balanced Score Card } \\ \text { COGTA } & - & \text { Cooperative Gov. and Traditional Affairs } \\ \text { IDP } & - & \text { Integrated Development Plan/Planning } \\ \text { IYDS } & - & \text { Integrated Youth Development Strategy } \\ \text { IYDS } & - & \text { Integrated Youth Development Strategy } \\ \text { KDA } & - & \text { Key Development Area } \\ \text { KFA } & - & \text { Key Focus Areas } \\ \text { KPA } & - & \text { Key Performance Area } \\ \text { KPI } & - & \text { Key Performance Indicator } \\ \text { LED } & - & \text { Local Economic Development } \\ \text { LM } & - & \text { Local Municipality } \\ \text { MSA(1) } & - & \text { Municipal Structure's Act } \\ \text { MSA(2) } & - & \text { Municipal System's Act } \\ \text { NDM } & - & \text { Nkangala District Municipality } \\ \text { NYC } & - & \text { National Youth Commission } \\ \text { NYDA } & - & \text { National Youth Development Agency } \\ \text { NYS } & - & \text { National Youth Service } \\ \text { PMS } & - & \text { Performance Management System } \\ \text { RDP } & - & \text { Reconstruction and Development Programme } \\ \text { SALGA } & - & \text { South African Local Government Association } \\ \text { SAYC } & - & \text { South African Youth Council } \\ \text { SDF } & - & \text { Spatial Development Framework } \\ \text { SMS } & - & \text { Strategic Municipal Scorecard } \\ \text { UYF } & - & \text { Umsobomvu Youth Fund } \\ & & \end{array}$




\section{TABLE OF CONTENTS}

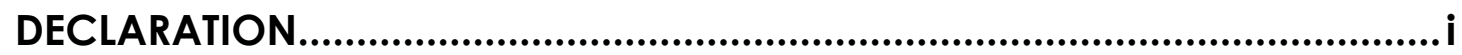

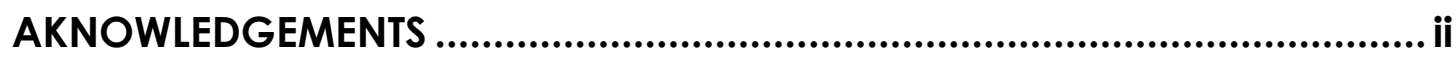

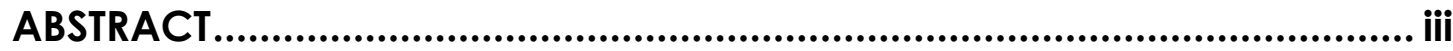

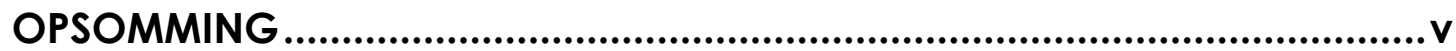

LIST OF ABBREVIATIONS .................................................................. vii

TABLE OF CONTENTS............................................................................. viii

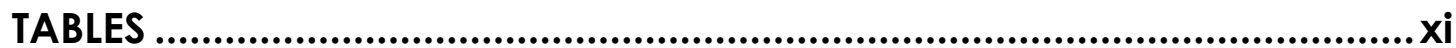

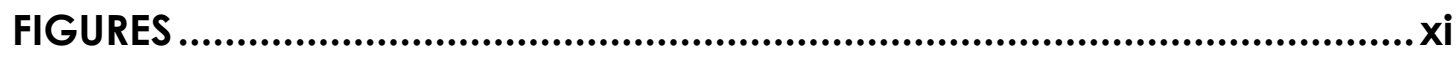

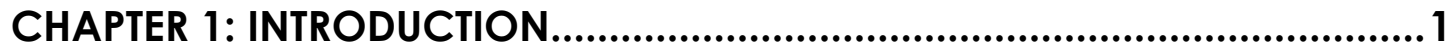

1.1. Introduction ......................................................................... 1

1.2. Background .......................................................................... 2

1.3. The Significance of the Study ................................................. 4

1.4. The Problem Statement............................................................. 5

1.5. Research Aim and Objectives ............................................... 6

1.6. Research Questions .............................................................. 6

1.7. Study Demarcation................................................................. 7

1.8. Research Methodology and Methods ................................... 8

1.9. Research Ethical Considerations ............................................... 9

1.10. Outline of the Study Chapters............................................... 9

1.11. Conclusion ............................................................................... 10

CHAPTER 2: PERFORMANCE MANAGEMENT IN LOCAL GOVERNMENT ....12

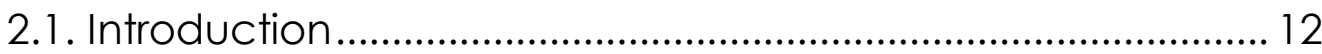

2.2. Defining Performance Management ..................................... 12

2.3. The History of Public Sector Performance Management ...... 14

2.3. Models of Performance Management Systems .................... 15

2.3. 1. The Balanced Scorecard ................................................. 15

2.3.2. The Strategic Municipal Scorecard.................................... 17

2.3.3. The Business Excellence Model .............................................. 18

2.4. Studies on PM in local government........................................ 20

2.5. Legislative framework on Performance Management ......... 22

2.5. 1. Municipal Systems Act (Act 32 of 2000) ............................... 23 
2.5.2. Municipal Planning and Performance Regulations (R769 of 2005)

2.5.3. Municipal Performance Regulations For Municipal Managers And Managers Directly Accountable To Municipal Managers (R805 Of 2006)....

2.5.4. The Municipal Finance Management Act (Act 56 of 2003)

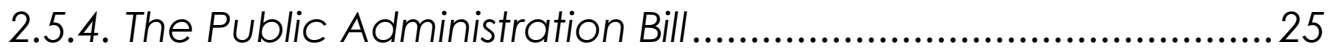

2.6. Performance Management Framework .................................. 26

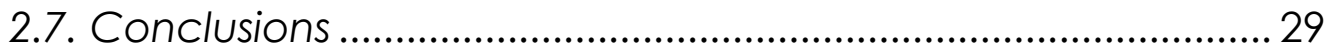

CHAPTER 3: YOUTH DEVELOPMENT IN SOUTH AFRICA ................................30

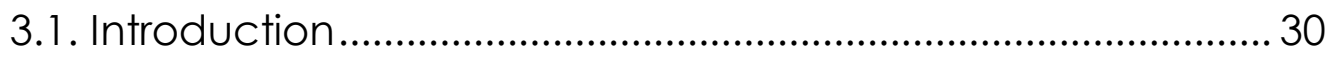

3.2. Defining Youth and Youth Development in South Africa ...... 31

3.2.1. Defining Youth in South Africa ............................................... 31

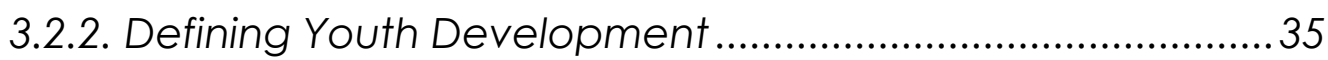

3.3. Evolution of Youth Development in South Africa ...................... 36

3.4. Approaches to youth development in South Africa ............... 40

3.5. Studies on Youth Development in South Africa ...................... 42

3.5.1. Status of Youth Work in South Africa ..................................... 42

3.5.2. Evaluation of Youth Development Programme at Swartland

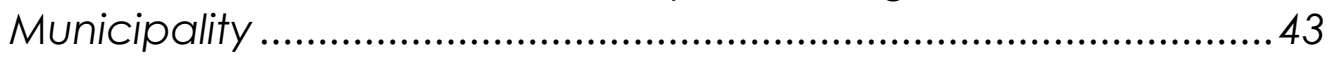

3.5.3. Integrating Youth Development in Free State ......................43

3.6. Youth Development Legislative and Policy Framework in South Africa .......................................................................................... 45

3.6. 1. Youth Development Legislative Framework ........................ 46

3.6.2. Policy Framework for Youth Development in South Africa. 49

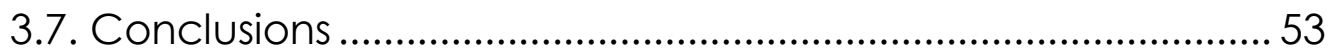

\section{CHAPTER 4: THE CASE OF NKANGALA DISTRICT MUNICIPALITY ...............55}

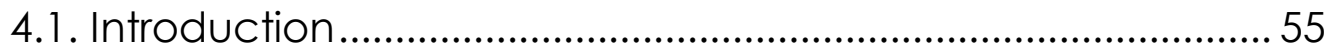

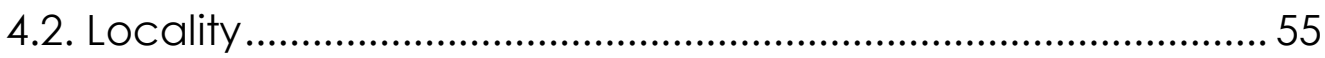

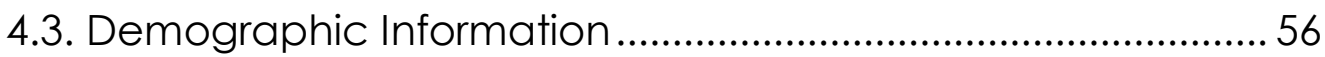

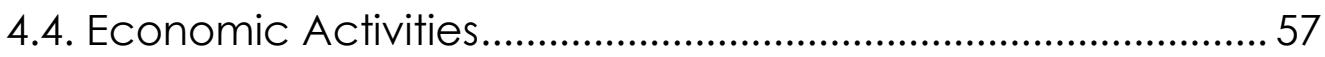

4.5. Education and Skills Development........................................... 58

4.6. Health and Wellbeing ............................................................... 59

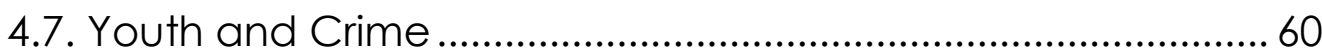

4.8. Youth Development Structures in the Municipalities within the

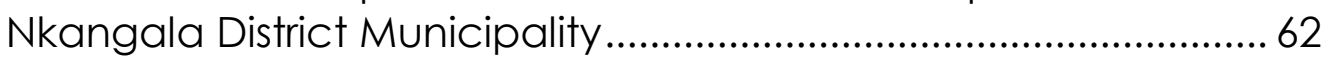




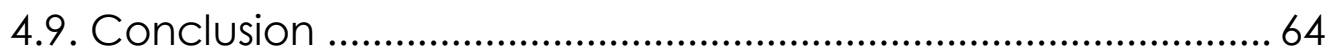

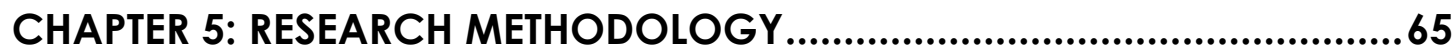

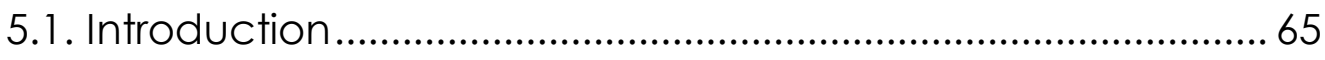

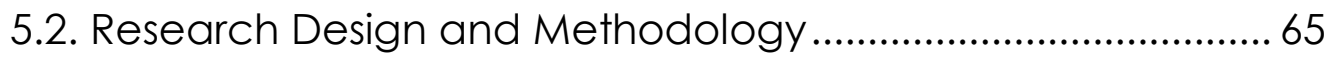

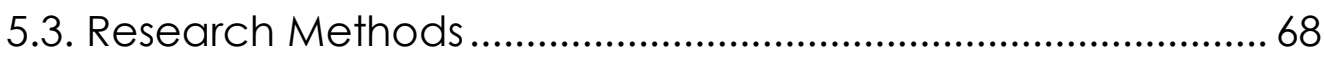

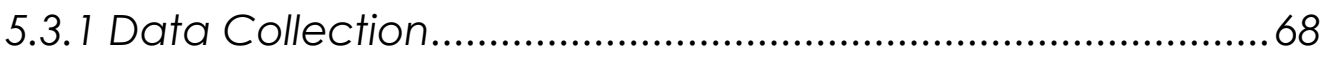

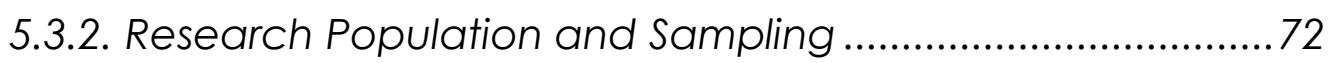

5.3.3. Reliability and Validity and Generalisation .......................... 72

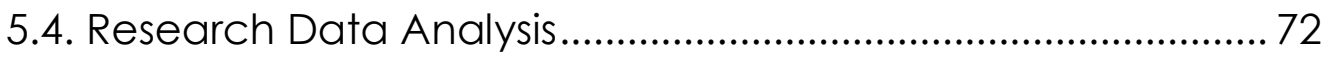

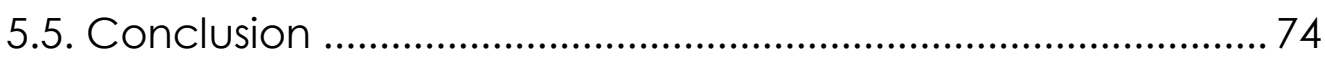

CHAPTER 6: ANALYSIS OF DATA AND RESULTS .......................................76

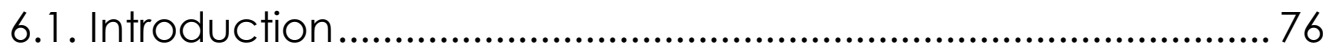

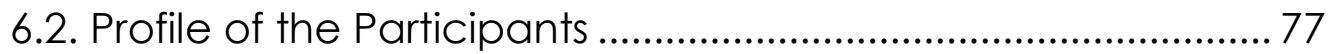

6.3. Youth Development and Youth Development Planning ...... 78

6.3.1. Defining Youth and Youth Development.............................78

6.3.2. The Nkangala District Municipality Youth Development

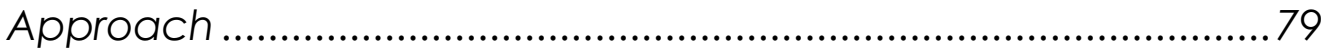

6.3.3. Youth Development Focus Areas in the Nkangala District

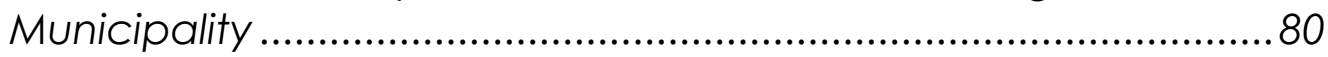

6.3.4. Youth Development Planning ............................................... 81

6.3.5. Youth Development and the Municipal Development

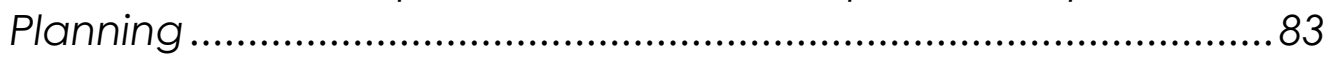

6.4. Youth Development Performance Management................... 84

6.4.1. Performance Management Framework ................................ 85

6.4.2. Performance Management Planning for Youth

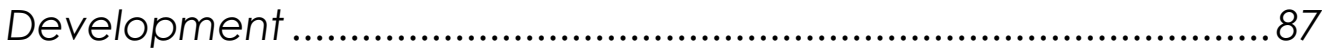

6.4.3. Youth Development Issues and Performance Plans ............88

6.4.4. Individual Performance Plans and Youth Development Targets.

6.5. PERFORMANCE MEASUREMENT AND YOUTH DEVELOPMENT 92

6.5.1. Youth development Key Performance Areas....................... 92

6.5.2. Youth Development Key Performance Indicators ............... 94

6.5.3. Performance Targets for Youth Development ................... 95

6.5.4. Integrating Youth Measures into the IDP and PMS ...........96

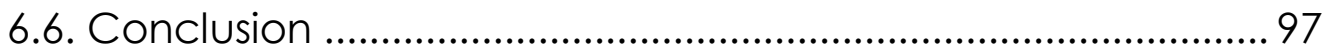

CHAPTER 7: SUMMARY, CONCLUSION AND RECOMENDATIONS ..............99 


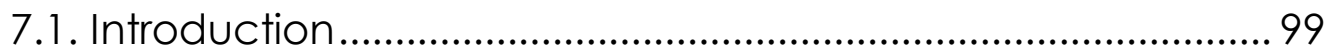

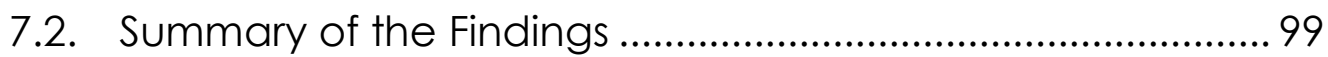

7.2. 1. Findings on Research Question 1 ...................................... 100

7.2.2. Findings on Research Question 2 ..................................... 100

7.2.3. Findings on Research Question 3 ...................................... 100

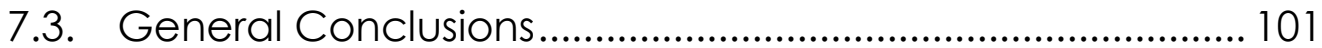

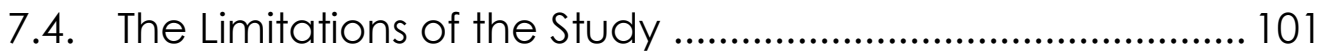

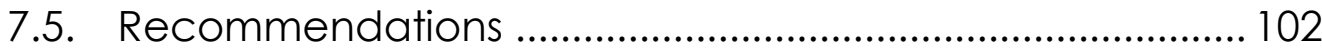

7.5.1. Recommendations in relation to Research Question 1.. 102

7.5.2. Recommendations in relation to Research Question 2.. 102

7.5.3. Recommendations in relation to Research Question 3.. 104

7.5.4. Recommendations for further research.......................... 104

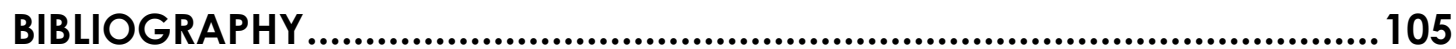

APPENDIX A: QUESTIONS FOR YOUTH DEVELOPMENT EXPERTS ..............111

APPENDIX B: INTERVIEW QUESTIONS FOR THE MANAGER: IDP ..............114

APPENDIX C: INTERVIEW QUESTIONS FOR THE MANAGER: PMS ............116

APPENDIX D: QUESTIONS FOR THE FOCUS GROUP DISCUSSIONS .........118

\section{TABLES}

Table 1: Concepts in the Excellence Model ............................................... 20

Table 2: Youth Segmentation ..................................................................... 33

Table 3: Tress Index of All Municipalities ......................................................... 58

Table 4: Crime Statistics by Local Municipality ............................................ 62

Table 5: Qualitative Approach versus Quantitative Approach ................66

Table 6: Alignment of Research Questions with Interview Questions..... 70

Table 7: Example of KPAs, KPIs and targets............................................... 96

\section{FIGURES}

Figure 1: Kaplan and Norton's Balanced Score Card .............................. 16

Figure 2: Performance Measurement and Review Model....................... 18

Figure 3: Business Excellence Model........................................................ 18

Figure 4: South African Excellence Model................................................. 19 
Figure 5: The Municipal Performance Management Framework........... 27

Figure 6: Population Pyramids, 2007 and 2037 .......................................... 45

Figure 7: Proposed Youth Unit Structure for Municipalities ........................ 52

Figure 8: Nkangala District Locality Map .................................................... 56

Figure 9: Population of the Nkangala District by Age and Gender ....... 57

Figure 10: Mpumalanga HIV/ AIDS Prevalence Results by District.......... 60

Figure 11: Crime Statistics by Crime Categories and Age Group ..........61 61

Figure 12: Qualitative Data Analysis (QDA) Process .................................. 73

Figure 13: Proposed Youth Development Performance Management

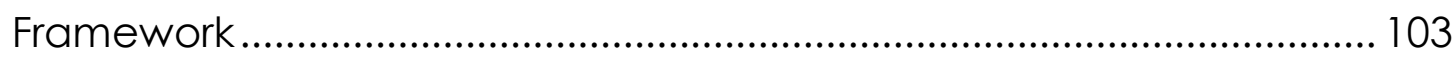




\title{
CHAPTER 1: INTRODUCTION
}

\begin{abstract}
"Today we also deliver this inaugural budget vote during Youth Month a month dedicated to youth development. The $16^{\text {th }}$ of June this year marks the $35^{\text {th }}$ anniversary of the Soweto and related Uprisings of 1976. It is the month in which young people braved all odds to fight for equal and quality education for all...Cabinet has decided to put local government as a standing item on its agenda so that we can monitor performance from a national level on a regular basis. In addition, the President will engage Premiers on how to improve the monitoring of the performance of municipalities, in terms of Section 139 of the Constitution."
\end{abstract}

(Hon. Collins Chabane, Minister of Monitoring and Evaluation, 2011).

\subsection{Introduction}

The recent uprisings in the world, including the "Arab Spring," were mainly activated and led by the youth of those countries. These revolts stem mainly from youth concerns over the chronic nature of economic exclusion, (Mail and Guardian: 2011)(Silatech: 2011).

Young people constitute large portions of the country population, and comprise the majority of the electorate. However, young people are, and remain the victims of poverty and unemployment; and arguably, as a result of being neglected by their governments. This point is further indicated in the World Youth Report published by the United Nations The World Youth Report states that for the year 2002 more than 700 million young people across the world were living in abject poverty (United Nations, 2005).

Apart from the Arab countries, Mozambique a country in the southern part of the continent, also experienced youth-led uprisings, stemming mainly over increases in food prices (Walsh, 2011). South Africa has not been immune to social uprisings led by young people. Since 2009 South Africa has been experiencing an avalanche of protests and uprisings, the main targets of which being municipalities. The social protests in South Africa are spurred by multiple factors, some of which include demands for greater access to education and training, economic opportunities. These issues continue to affect young people, defined as those aged between 18 and 35 years. This state of the youth also leads to major concerns, specifically in relation to poor skills, irrelevant and poor education, hopelessness and the hardening youth attitudes towards authorities and the government, hence the protests (RSA, 2008b: 1).

Undoubtedly, this calls for more and improved programming on youth development. These interventions must respond to the challenges that South African youth are facing. A clearer and firmer concretisation of a common understanding of youth development should be (as well as civic education), 
becomes a fundamental necessity. Intentional and conscious planning for youth development has to be in place in order to guide intervention processes.

Institutions of youth development will have to place more emphasis on the implementation and monitoring of youth development programmes. This must be done with the concern for the reduction of the backlogs on youth development in mind (RSA, 2008b: 34).

This study provides an elaborate insight into the intricacies underpinning the challenges of realising successful youth development programmes and interventions. A special focus will be on Nkangala District Municipality (NDM) and the six (6) Local Municipalities within the NDM namely Emakhazeni, Steve Tshwete, Emalahleni, Victor Khanye, Thembisile Hani and Dr JS Moroka. These municipalities will be used as a case study to analyse and evaluate the usage of performance management in guiding youth development within the local government sector in South Africa.

This chapter provides a brief background on youth development and performance management in local government as well as the rationale and motivation for the study. It will outline the aims and objectives of the study, problem statement, preferred research methodology and methods. In addition, this chapter will also provide an outline of the subsequent chapters of the rest of the study. In short, this chapter aims, without providing elaborate detail, at acquainting the reader with the scope of the study.

\subsection{Background}

The concept of youth development was formally introduced to the government of South Africa through the African National Congress (ANC). The Reconstruction and Development Programme (RDP) adopted in 1994 set the tone for the developmental trajectory that South Africa had to pursue. Among other things, the RDP also outlines what was expected and is still expected in terms of youth development (ANC, 1994: 73-74).

This led to the formation of the National Youth Commission (NYC). The initial and main conceptualisation of the NYC was that it would act as a lobby and advocacy institution, seeking to mainstream youth development imperatives across society and its institutions. At the beginning of its existence, the NYC pursued this mandate by mainly participating in the various planning processes of the government departments and municipalities. Later on in 2001, the NYC was complemented by the Umsobomvu Youth Fund (UYF); a schedule 3b entity, in terms of the Public Finance Management Act, and whose two-fold mandate was to fund and support the economic development of youth and finance the up-skilling of youth. As a schedule b entity, the UYF was more autonomous than 
the NYC. This was also further complemented by the capitalisation of the UYF by $\mathrm{R} 1$ billion rands.

Breathing life to the assertions of the RDP (ANC, 1994), the Constitution of the Republic of South Africa (RSA) (RSA, 1996a: 51 and 53), the Municipal Systems Act (RSA, 2000: 46) and its Amendment Act (RSA, 2003a), spell out the need for performance management in the municipalities. In this regard, the implication is also extended to the organisational and the individual performance management including the performance management of the youth development managers in the municipalities.

The responsibility and mandate for social and economic development is placed on the municipalities in terms of section 152 of the Constitution (RSA, 1996a: 49), as one of the critical objects of local government. Youth development is understood to be amongst the many legs of socio-economic development. Thus it makes sense for youth development responsibility to be cascaded down to local government, since municipalities are the first government line of contact with the electorate and the citizens of South Africa.

In all the municipalities within the Nkangala District Municipality (NDM) youth development projects have either been included in the Integrated Development Plan (IDP) or an Integrated Youth Development Strategy (IYDS) for the local youth has been developed and adopted by the council. These strategies were to be implemented over the last period of four to five years. Complementing youth development Units were to be established and they would be made up of the youth development Managers (YDMs), youth development Co-ordinators and Project managers.

Nkangala District Municipality (NDM) has six local municipalities falling under its area of jurisdiction. The municipalities within the NDM have made some progress as far as youth development function is concerned. Almost all have adopted the Strategies for youth development and have also established youth development units that are manned by at least a youth development manager or a youth development Co-ordinator. There is however, a challenge in that there is a conspicuous need for a performance management system for youth development management, both at organisational and individual level. This could be gathered from the annual youth development summits that the municipalities would hold every year. In these meetings, issues similar those discussed in the previous year would still be raised as if they were new altogether. Clearly, there are no systems in place to monitor the implementation of the agreed upon programmes for youth development. 
Despite this progress the NDM is making, there is however, a glaring need for a performance management system for youth development management, both at organisational and individual level. This is evident in the discussions arising in the annual youth development summits that the municipalities would hold every year. In these meetings, issues similar those discussed in the previous year would still be raised as if they were new altogether. More often there would be a feeling of déjà vu in the delegates because indeed they would have discussed these matters are repeated over and over again without any material progress reported on the implementation. Clearly, it can be assumed that this situation exists because there are no systems in place to monitor the implementation of the agreed upon programmes for youth development.

\subsection{The Significance of the Study}

The significance of this study is best defined in terms of its potential to contribute to the existing body of knowledge in the area of one of the contemporary subjects of development, socio-economic development and youth development. A special contribution will be to the subject of the use of performance management methods on youth development programmes. South Africa needs a guided approach towards an integrated and mainstreamed youth development as espoused in the National Youth Development Act (No. 54 of 2008).

It is common knowledge that since the establishment of Umsobomvu Youth Fund (UYF) and the National Youth Commission (NYC), there have been some interventions towards sound youth development in South Africa (NYC and UYF Annual Reports for 2009). This claim is further backed by the Status of the Youth Reports (1999 and 2005). The real test arises when the question of the effectiveness of all interventions in reducing the glaring youth development backlogs and whether through such interventions, we are dealing with the inherent youth development problems as defined and understood in the studies conducted.

It is common knowledge that since the establishment of Umsobomvu Youth Fund (UYF) and the National Youth Commission (NYC), there have been some interventions towards sound youth development in South Africa. This assertion is backed by the Status of the Youth Reports (1999 and 2005). The real test arises when the question of the effectiveness of all interventions in reducing the glaring youth development backlogs and 
the decisiveness of such interventions in dealing with inherent problems is posed.

This study seeks to contribute to the already existing interventions by guiding the youth development fraternity towards finding a framework for youth development performance management so as to improve the effectiveness of current programmes and to reduce the backlogs.

\subsection{The Problem Statement}

As hinted by Nealer (in Van der Waldt, 2007: 177), there is a need for municipalities to develop comprehensive performance management systems. This inherently extends to youth development programmes in the municipalities. Informal and preliminary discussions with youth development managers and other stakeholders indicate that there is a conspicuous lack of a systematic approach to managing the performance on youth development in municipalities within the Nkangala District Municipality. As a result, it is difficult to manage performance monitoring of the YDM's in the municipalities.

When there is no performance management, particularly relating to planning, implementation, monitoring, assessment, evaluation and review, service delivery outcomes will either be distorted or not be communicated adequately. This situation results in the lack of determination of whether the implemented programmes achieve their desired outcomes or not. Therefore, the research problem can be framed as:

The absence of a tailor-made performance management framework for youth development in local government hinders the performance of youth development programmes. Inevitably, such an absence affects the possibility of attaining the set targets in relation to youth development outcomes.

Leedy (2005: 51) states that a research problem can be subdivided into subproblems. This affirms the old strategic principle of divide and conquer. The more simplified the research problem is, the more possible it is to resolve it. Accordingly, for the purposes of the study in question, the following are the subproblems that stem from the main research problem as stated above:

- As it stands there is no uniform understanding of what municipalities should be doing in order to realise an effective youth development programme. What compounds the problem is that there is no common framework either in the form of separate plans or sections in the IDPs' defining a common youth development agenda.

- There is currently no clarity on the application of the performance management framework on youth development by the 
municipalities as a tool to ensure successful implementation of the youth development programmes.

- Performance management plans at both organisational and individual level in local government does not clearly spell out key development areas, performance indicators and targets for youth development.

\subsection{Research Aim and Objectives}

The overall aim of this study is to evaluate the current performance management approaches taken in youth development in selected municipalities, and to make recommendations on the improvement thereof. The study aims to establish a framework for youth development, appropriate key development areas for the youth in local government, and a framework for the application of existing performance management system on youth development.

The research aim is underpinned by the following research objectives:

- The study seeks to establish a common framework for the youth development agenda and youth development planning in local government by way of deductions arising out of the literature review.

- It seeks to establish whether in the NDM, the performance management approach for youth development programmes is uniformly applied in the selected municipalities. This will be done by assessing the existing documents; such as IDP's, SDF's, LED plans, performance management, youth development strategies and annual reports.

- The study will assess the appropriateness of the current performance measures for youth development in the municipalities within the NDM. This will be done by conducting one-on-one interviews and focus group discussions with selected municipality and national level representatives.

- In conclusion, the study will attempt to suggest the possible mechanisms of closing the gaps between the envisaged state and the reality of youth development performance management in the Nkangala district.

\subsection{Research Questions}

Research questions can be derived from the research objectives in order to guide and simplify the research process. Unlike the hypotheses, the research questions are not meant to give speculative answers to the research problems, but they serve to further clarify the problem and what the researcher should be looking for (Leedy, 2005). 
For the purposes of this study, the following research questions were derived from the research objectives:

- What is/are the factor(s) that currently define(s) the youth development agenda and youth development planning in Nkangala District Municipality?

- Does the municipality make use of the performance management systems on youth development in local government?

- Does the municipality have clearly defined performance measures to monitor progress on youth development, i.e. KPA's, KPI's and targets?

\subsection{Study Demarcation}

As indicated by Leedy (2005: 3), the research study has to be focused and manageable. This means that the study must be within a realistic reach, taking into account time and the resources available for the study. For this reason, the study will not delve into the details and specificities of individual performance management.

The researcher has worked for two municipalities within the NDM and has also worked with the NDM on numerous development planning projects, including youth development planning projects. The experience and knowledge of the researcher is very important for a more specific insight into the workings of the NDM and its local municipalities. For the same reasons, the study focuses on Nkangala Destruct Municipality and to some extent, the Local Municipalities within NDM Jurisdiction namely, Dr JS Moroka, Victor Khanye, Thembisile Hani, Emakhazeni, Emalahleni, Steve Tshwete local municipalities.

The empirical research through face to face interviews and group discussions will be administered through questions to participants within the municipalities and institutions for youth development under NDM. The following is a list of the targeted participants:

- the Municipal Manager of NDM;

- the Executive Mayor of NDM;

- seven youth development managers or Co-ordinators, including those from local municipalities;

- a senior official responsible for Performance Management in the NDM; and

- seven participants from the South African Youth Council, including six from the local municipalities' structures.

The total number of participants will be limited to 18 people. 
Although some consideration will made on the framework documents at national and provincial levels, the study will be limited to performance management in relation to youth development within local government.

\subsection{Research Methodology and Methods}

Chapter 5 will give elaborate information on the subject of the study's research methodology and methods.

The researcher opted to be guided by the qualitative research methodology. The study will be mainly based on activities ranging from literature reviews to an empirical enquiry. The researcher aims to find, explore and review relevant literature material regarding youth development and performance management in local government. To this effect, both academic and nonacademic studies in the fields of youth development and performance management will be utilized. These studies will be selected from the public sector and local government in particular. The researcher will also consider the available legislative and policy material relevant to the themes of youth development and performance management. The aim of this activity will be to establish a common working understanding on the subject, but more so, to lay the foundation towards the establishment of a resolve to the research problem and its subproblems.

A desktop review of the NDM's document is necessary. The NDM's 2009/2010 Integrated Development Plan, and other youth specific strategies will be reviewed. Additionally, the NDM's 2009/2010 annual report will be reviewed. These documents will be reviewed in order to establish the status of youth development in the NDM. In particular, the 2009/2010 annual report will be reviewed in order to establish the progress achieved on youth development in NDM.

Additionally, the NDM's performance management framework will be reviewed in order to describe how performance management is undertaken by the NDM. The review of the NDM's performance management framework is important as it allows the researcher to establish the levels of compliance achieved.

This NDM documentary review is also important as it will enable the development of research instruments. Thus, guided by the research objectives and the results of the literature and documentary review, the researcher will administer the research instruments through semi-structured interviews. The interview questions will be tailor-made for all the participant groups of the study. Focus group discussions are a form of data and participant triangulation. Here, the researcher is able to validate the information generated from the interviews and documentary review. Additionally, there is an element of participant empowerment. This it is hoped, will occur through the sharing of information and 
lesson learned in the focus groups. The findings and conclusions of the entire study will be informed by the results from this empirical investigation.

It also important to highlight that the researcher has worked in the youth development field and within the NDM for over ten years. During this period, he worked as a senior and accounting officer for over five years. He was instrumental in the development of plans and strategies in some municipalities in the area, including IDP's and youth development strategies. This experience, exposure and capacity will be instrumental when conducting the empirical study, especially the group discussions.

\subsection{Research Ethical Considerations}

The researcher was guided by standards of professional ethics pointed out by Mouton (2008: 240-248). All the participants were informed of the purpose of the intended study. All forms of plagiarism have been avoided as far as it was practically possible. Where by error, a source was not acknowledged, the researcher has apologised in the acknowledgement section. Findings were monitored and triangulated for validation purposes, from the literature review, secondary data analysis, interviews and group discussions. Where participants requested not to be named as sources of information, the researcher maintained confidentiality accordingly.

An undertaking was made to the participants, who are youth development practitioners themselves, that the final report on the study shall be made available to them on request.

\subsection{Outline of the Study Chapters}

The research report is envisaged to compose of chapters arranged in the following sequence:

\section{Chapter 1: Introduction}

This chapter will outline the stimulus of study, the background to the study, the significance of the study, the research problem statement and sub-problems, research aims and objectives, research questions, the demarcation of the study, research design and methods, research ethical considerations and the study chapter outline.

\section{Chapter 2: Performance Management in Local Government}

In this chapter, the researcher will critically outline the theories and models of performance management in local government and the legislative framework for performance in South Africa. Studies conducted in the field of performance management, particularly in local government are reviewed. The researcher does however consider other studies in other spheres of government. Both organisational and individual performance management literature are 
considered. The purpose of this chapter is to establish a common working framework for the purposes of the study.

\section{Chapter 3: Youth development in South Africa}

The purpose of this chapter is to examine the existing and available literature, and theories on youth development. Critical to this section is the Status of the Youth Report, the Youth Development Strategies by Government Departments and Public Entities. The chapter also reviews the legislative and policy framework in South Africa. This chapter aims to establish common definitions for youth and youth development.

\section{Chapter 4: The Case of Nkangala District Municipality.}

This chapter introduces the study case i.e. Nkangala District Municipality. Central to this, will be the coverage of the municipalities within its jurisdiction, namely, Victor Khanye, Emakhazeni, Steve Tshwete, Thembisile Hani, Emalahleni and Dr JS Moroka Local Municipalities. The researcher will also look at the structures of youth development in this municipality. In addition, the chapter will evaluate and assess the state of youth development and performance management in the NDM.

\section{Chapter 5: Research Methodology}

This chapter outlines the philosophy guiding the study and the tools used to carry out the study. The methods to be used in the study to analyse data are also explained in the chapter. This segment of the study is more elaborate than the section provided for in Chapter One.

\section{Chapter 6: Presentation and Analysis of Data and Results}

This chapter seeks to present and evaluate the data collected in line with the literature review and objective of the research. The data will be analysed and the results will discussed.

\section{Chapter 7: Summary, Conclusion and Recommendations}

The conclusion chapter, first summarises the key findings of the study and thereafter makes recommendations accordingly. The recommendations will include a proposal towards a Youth Development Performance Management system for municipalities.

\subsection{Conclusion}

It is certain that youth development is increasingly occupying the centre stage in the development arena. The normative developmental concerns are becoming more and more dominated by issues of youth development. This is also the case in South Africa. Government interventions have to be more biased to youth development. This also calls for the monitoring and evaluation of the same interventions in order to guarantee meaningful impact on young people's 
needs. Performance management as provided for in local government could be of assistance.

In this study an elaborate literature review on youth development and performance management in local government will be integrated and upraised to establish a common understanding of the subject area. This understanding will be used as the basis for evaluating the subject municipalities within NDM and draw closer to the study findings and conclusions.

As already indicated, the study has seven chapters i.e. The Introduction, Performance Management in Local Government, youth development in South Africa, Overview of Nkangala District Municipality, Research Methodology and Methods, Analysis of Data and results as well as Summary, Conclusions and Recommendations 


\title{
CHAPTER 2: PERFORMANCE MANAGEMENT IN LOCAL GOVERNMENT
}

\begin{abstract}
"...we are of the view that monitoring and evaluation has the potential to make a very significant contribution to good governance. However, the realisation of this potential is dependent on the way in which the monitoring and evaluation mechanisms are designed and implemented...Good intentions are not enough - badly designed monitoring and evaluation initiatives often result in more negative than positive consequences. Our system is based on negotiated and agreed upon processes, outputs and targets within government."
\end{abstract}

(Hon. Collins Chabane, Minister of Monitoring and Evaluation: 2011).

\subsection{Introduction}

From the onset, it is important to highlight that literature on performance management, especially for local government, is overwhelming in as much as there are equally numerous models of performance management. South Africa has put in place a variety of policies and pieces of legislation on the subject of performance management. Notwithstanding, it is also crucial to point out that performance management has been adopted by the public sector and the private sector. In fact, performance management has gained credence for governments the world-over. Its adoption by the public sector was primarily informed by the need to improve service delivery. Performance management must be understood as spanning over two dimensions, namely institutional or organisational and individual performance management, (Van der Waldt: 2007: 110-111). For the purposes of this study, the focus is on the institutional dimension, and more particularly in relation to its application on youth development.

This chapter will focus on the definitions of performance management, theories (models) of performance management, the local government legislative framework on performance management and some studies conducted on the performance management.

\subsection{Defining Performance Management}

As stated above, a great deal of literature exists on the subject of performance management. Given the fact that much has been theorised on performance management, it stands to reason that there would be multiple understandings and definitions of the area. In this section of the study, the researcher explores and problematises the numerous definitions attached to the concept. 
Performance Management is defined by Cokins (2004:1) as:

"...the process of managing the execution of an organisation's strategy. ...it comprises of methodologies, metrics, processes, software, tools, and the system that manage the performance of an organisation."

This definition is further elaborated by Atkinson (2001: 554) who observes that performance management is:

"an approach to management which emphasizes outputs, results, and productivity, of both individual officials as well as the institution as a whole."

Keyes (2005:28) as cited in Jantjes (2008: 11-12) defines performance management as:

"the use of performance measurement information to effect positive change in the organisational culture; systems and processes by helping to set agreed-upon performance goals, allocating and prioritizing resources, informing managers to either confirm or change current policy or programme directions to meet those goals, and sharing results of performance in pursuing these goals."

Keyes's (2005) definition acknowledges that performance management involves a deliberate and proactive intervention by managers, ensuring that the culture, systems and processes are constantly adjusted and improved to assist the organisation in meeting its set performance goals. The fundamental element of Keyes's definition is that he sees performance management as a process of assessing progress towards achieving set performance goals.

Costello (1994: 3) as cited by Jantjes (2008: 14) argues that performance management must link the work of individual employees to the organisational overall goals of the organisation and the mission of the work units. To this effect, clear performance goals for individuals have to be established and be used for ongoing coaching and performance management. This perspective is also supported by Craythorne (2003:192) who asserts that the purpose of performance management is to establish a process whereby the vision and goals of an organisation can be met.

For the purposes of this study, and accruing out of the above definitions, performance management can be defined as a deliberate process of ensuring that the set goals and the agreed upon targets are achieved through instantaneous interventions by management and leadership. This has its ultimate 
focus on the performance of the organisation. It is however, underpinned by the performance of individuals within the organisation.

\subsection{The History of Public Sector Performance Management}

The discussions on performance management in the public sector was preceded by extensive theorisation on public management reform. In the 1950's, public management was limited to technical or legal concerns of running governments, it was neither about politics nor economics. Thus the initial debates into public management reform, were even deemed to be just about the dull organisational and procedural changes (Osborne and Gaebler, 1992: 12-16). During this period, countries would discuss the issue of the reform internally and in isolation from the world. This was justified by the reason that each country has its own culture and peculiar circumstances. Glaringly, there was little or no coordinated effort to shape the debates at the international level and scale. (Pollitt and Bouckaert, 2011:5-6)

During the 1980's there was a strong movement to debate the idea of public management at the international level. There were many forums that were used to advance the discourse, including the Organisation for Economic CoOperation and Development(OECD) and United Nations Public Administration Network(UNPAN), that were used to advance the public reform discourses in the form of the comparative public administration. At the centre the discourse placed the western models of public management as the most ideal to follow. These reforms were concerned about the rational strategic policy making and the economic disturbances which seemed to overburden the governments. Correctly or otherwise, this was coupled with the notion that the western welfare states were becoming unaffordable, ineffective and overstraining. (Pollitt and Bouckeart, 2011:9)

A number of models addressing public management reform were introduced within this context. Amongst others Neo-Weberian State (NWS) model, the Nordic model, New Public Governance(NPG) model and the New Public Management model (NPM) (Pollitt and Bouckaert, 2011: 18-19). For the purposes of this study, lessons can be drawn from the NPM since the study is intended to focus on measuring the inputs, outputs and outcome for youth development in South Africa.

The NPM was in essence based on the need to reinvent governments to do business more in an entrepreneurial, market-based, results-orientated peopleand customer-driven manner (Osborne and Gaebler, 1992: 1-34). It was based on the following principles:

- reliance on a lean, flat, small and specialised organisational forms.

- widespread substitution of contracts 
- treating public services users as customers thus the application of techniques such as the Total Quality Management (TQM) (Batho Pele Approach in South Africa)

- a widespread injection of market-type mechanisms(MTM's)

- and more relevant to the study, the emphasis on performance management. (Pollitt and Bouckaert, 2011: 9-10)(Osbourne and Gaebler, 1992: 195-198)

These debates inevitably led to the invoking of performance management theories and models and the application thereof in the public management. As indicated earlier in this section, the proponents of the NPM emphasised the improvement of efficiency and effectiveness of the public sector; efficiency meant a better output over input ratio, whilst the effectiveness referred to the impact realised by achieving the outputs.

(Pollitt and Bouckaert, 2011: 15,16, 106-110; Osbourne and Gaebler, 1992: 38165).

\subsection{Models of Performance Management Systems}

Local government in South Africa can draw on a variety of performance management models; however, the most popular and preferred approach is the balanced scorecard (BSC). The BSC was adapted and transposed from the South African private sector to the public sector.

\subsubsection{The Balanced Scorecard}

Kaplan and Norton (2007), influenced by the realization that reviewing only the financial aspects of organisations was not sufficient for $21^{\text {st-century success, }}$ studied best practices in performance management in twelve companies. The study culminated in the development of the Balanced Score Card Model.

Kaplan and Norton's balanced scorecard approach has been upgraded and clarified through at least three generations (Cobbold and Lawrie, 2002:1-2). In its basic and original form as was developed by Kaplan and Norton, the BSC is made up of four perspectives of finance, innovation and learning, internal business, and customer. This is supported by Niven (2005: 13-16) who also observes that the Balanced Score Card is centred around four perspectives: the financial perspective, the customer perspective, the internal processes perspective and the learning and growth perspective. 
Figure 1 illustrates the BSC as it was originally developed by Kaplan and Norton (2002).

Figure 1: Kaplan and Norton's Balanced Score Card

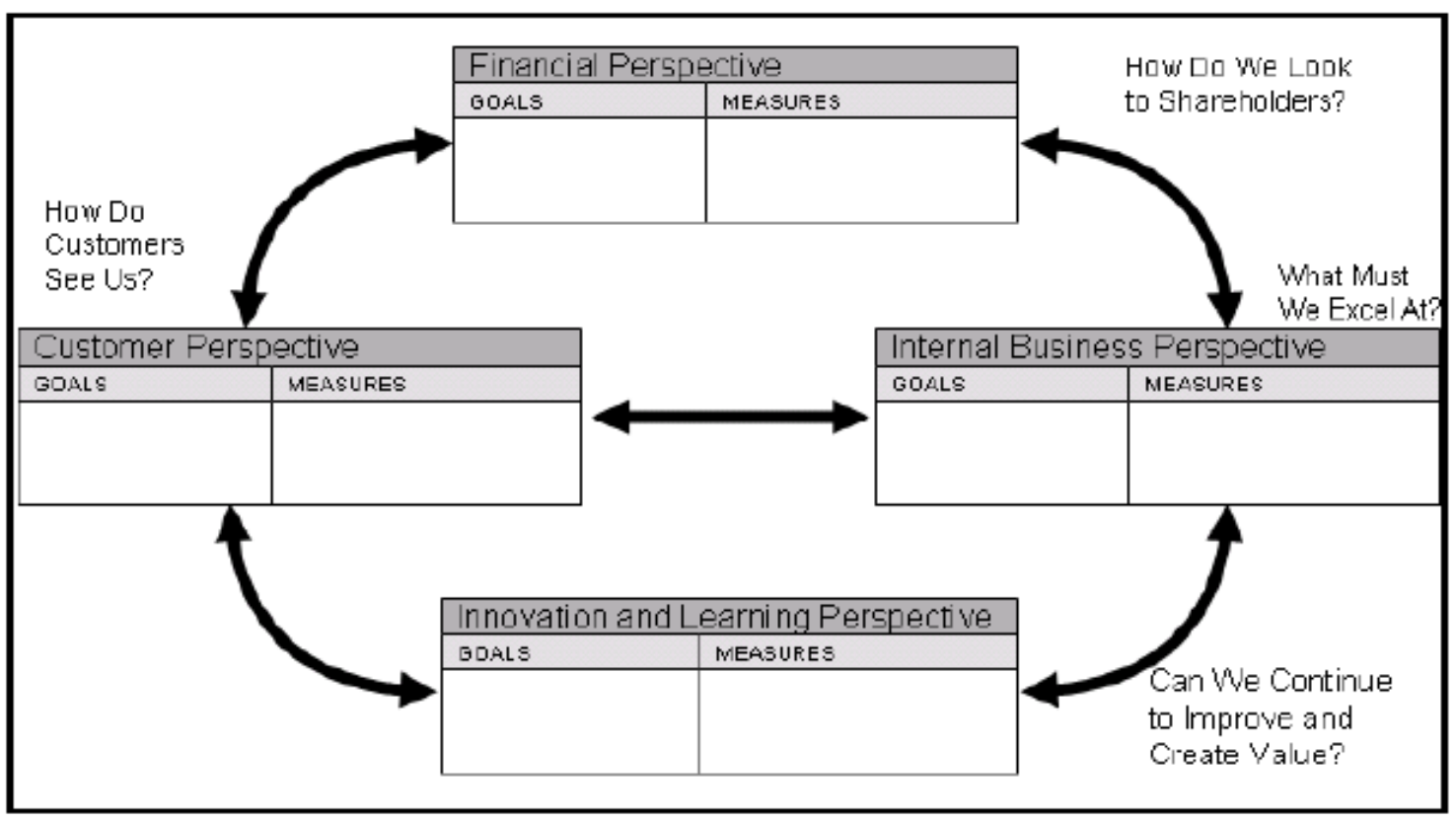

Source: Cobbold and Lawrie (2002: 2)

\section{Financial Perspective}

Financial measures remain important components of the balanced score card. This applies for both profit and non-profit organisations as well as public entities. Indicators under this perspective involve revenue, profitability and budget variances. The degree of importance will vary from profit to non-profit to the public sectors.

\section{Customer Perspective}

Authors in performance management agree on the need to respond to two basic questions when choosing a customer perspective. These questions are:

1) Who are the targeted customers?

2) What is your proposition in serving those customers?

\section{Internal Processes Perspective}

This involves the identification of key processes, in which the organisation needs to excel in order to improve its ability to satisfy customers. It could also involve the sharing of services and processes by various business units. At times to satisfy customers the organisation might need to identify entirely new internal processes.

\section{Learning and Growth Perspective}

This perspective is commonly described as an enabler. It is also known as the employee learning and growth perspective. The lay measures and performance 
drivers will include employee skills, employee satisfaction, availability of information and alignment.

Ghosh and Mukherjee (2006: 68-69) argue that it is a fact that the BSC is superior theoretically. However, the shortfall is that it is not yet widely accepted. This is attributed to the practical difficulties in its development and implementation. The argument is contradicted by the findings in the earlier study by Cobbold and Lawrie (2002: 1-2), in which they argue that the BSC is widely accepted and used. Furthermore, it is asserted in the study that the implementation thusfar has been worthwhile.

A worrying factor for the public sector in general and for local government in particular is that the BSC will have to be adapted to suit the industry. In many instances where the BSC is utilised by municipalities as the performance management model, it does not properly synchronise with the outcomes expected by the communities.

\subsubsection{The Strategic Municipal Scorecard}

According to the Performance Management Guidelines for Municipalities (RSA, 2001c: 30), the Strategic Municipal Scorecard (SMS) is an integrated model that has been developed and is suggested for use in local government performance measurement in South Africa. The model is consistent with the performance management framework outlined in the Municipal Systems Act (2000) and the Performance Management Regulations (2001c). These guidelines provide that, in measuring performance, municipalities need to look at:

- The economy and efficiency of inputs to produce outputs, for example resources or financial perspectives;

- The effectiveness of activities / processes to produce outputs (results, service delivery perspectives);

- The impact of outputs on the overall achievement of objectives, for example, customer satisfaction, growth and quality of life.

This model, the Municipal Scorecard, is based on four key perspectives, as outlined in Figure 2: 
Figure 2: Performance Measurement and Review Model

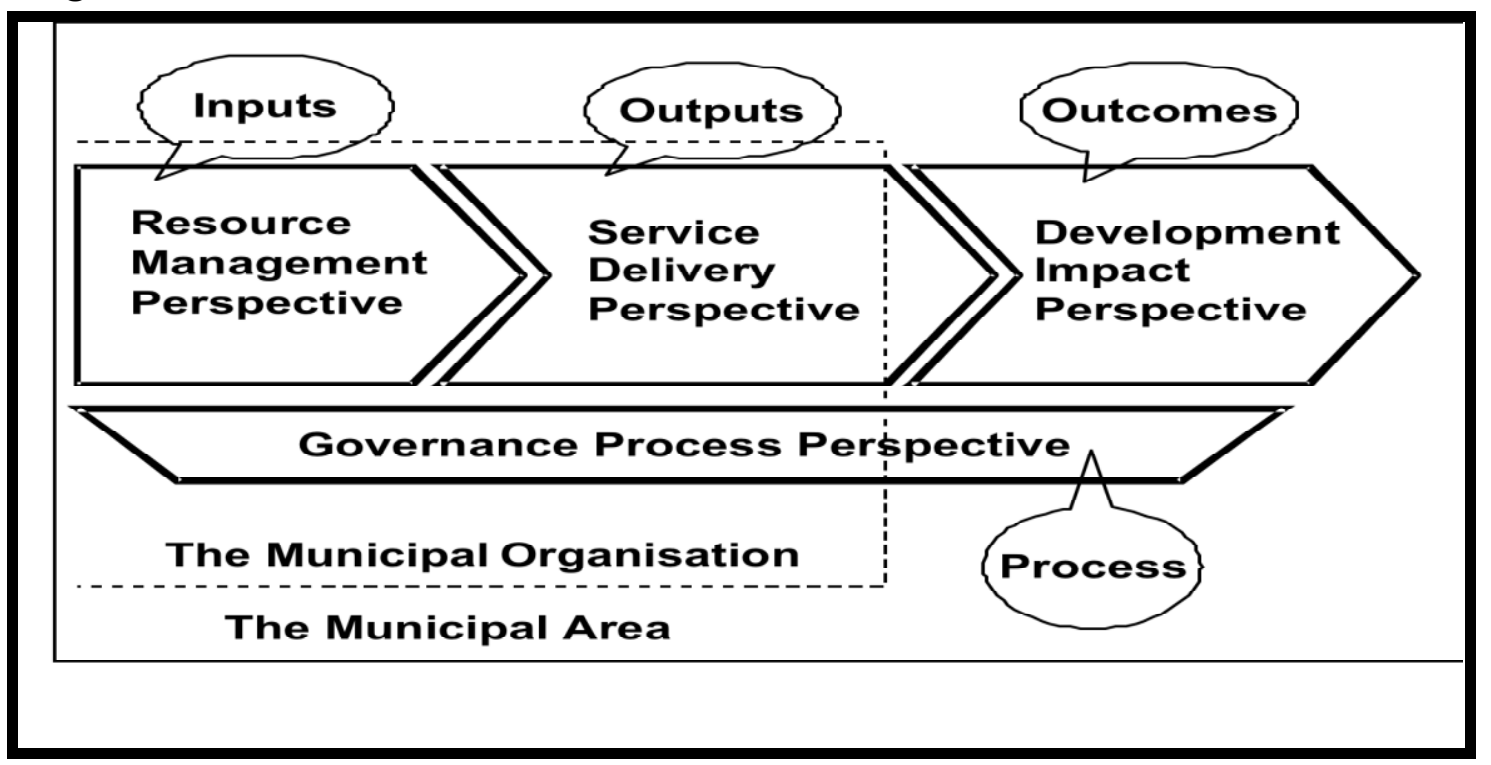

Source: PM Guidelines for Municipalities (RSA, 2001 c: 30)

\subsubsection{The Business Excellence Model}

According to Roos (2009:40), "the South African Excellence Model is premised on excellent results with respect to performance, customers, people and society." He asserts that this is achieved through leadership, driving policy and strategy that is delivered through people partnerships and resources, and processes. This Model is also referred to as the "European Foundation of Quality Management (EFQM) Model" by Jantjes (2008:19-20). Figure 3 illustrates the Model:

Figure 3: Business Excellence Model

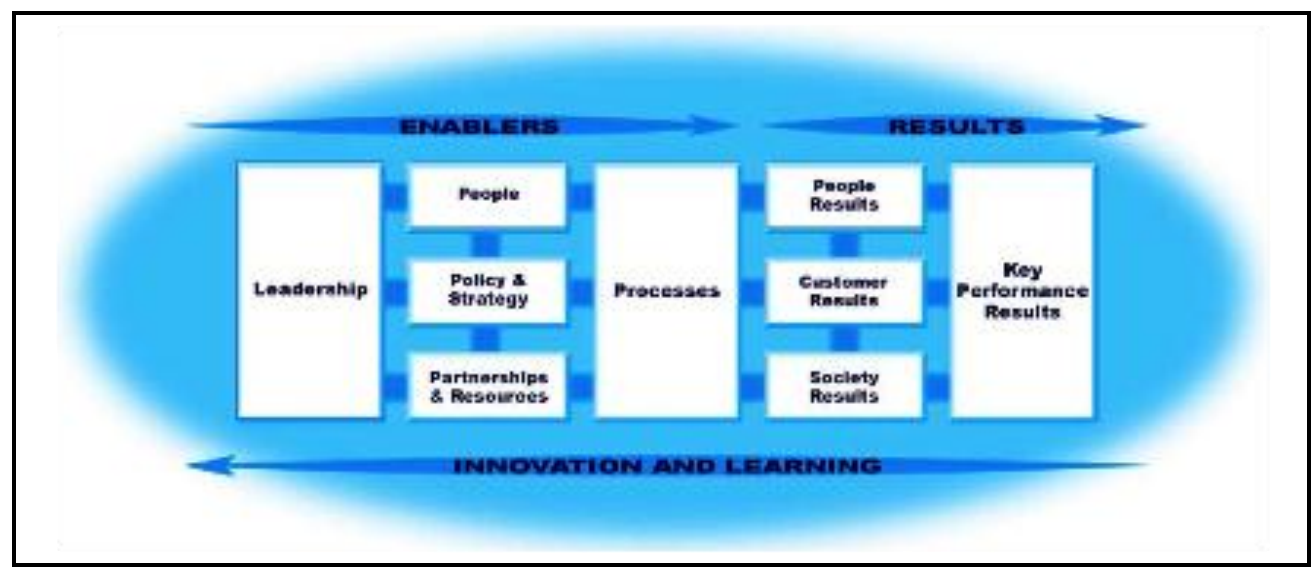

Source: Roos (2009: 32)

Leadership, People Management, Policy and strategy, Resource and Processes are identified as "enablers, whilst people satisfaction, customer satisfaction impact on society and Key Performance Results are identified as "Results" (Armstrong and Baron, 2005:118 as cited by Jantjes, 2008:19). 
The Business Excellence Model influenced the South African Excellence Model. However, the South African Excellence Model slightly differs from the Business Excellence Model in that the former included customer and focus, and information Management as enablers. It also included supplier and partnership performance as a result (Jantjes, 2008:22).

Figure 4: South African Excellence Model

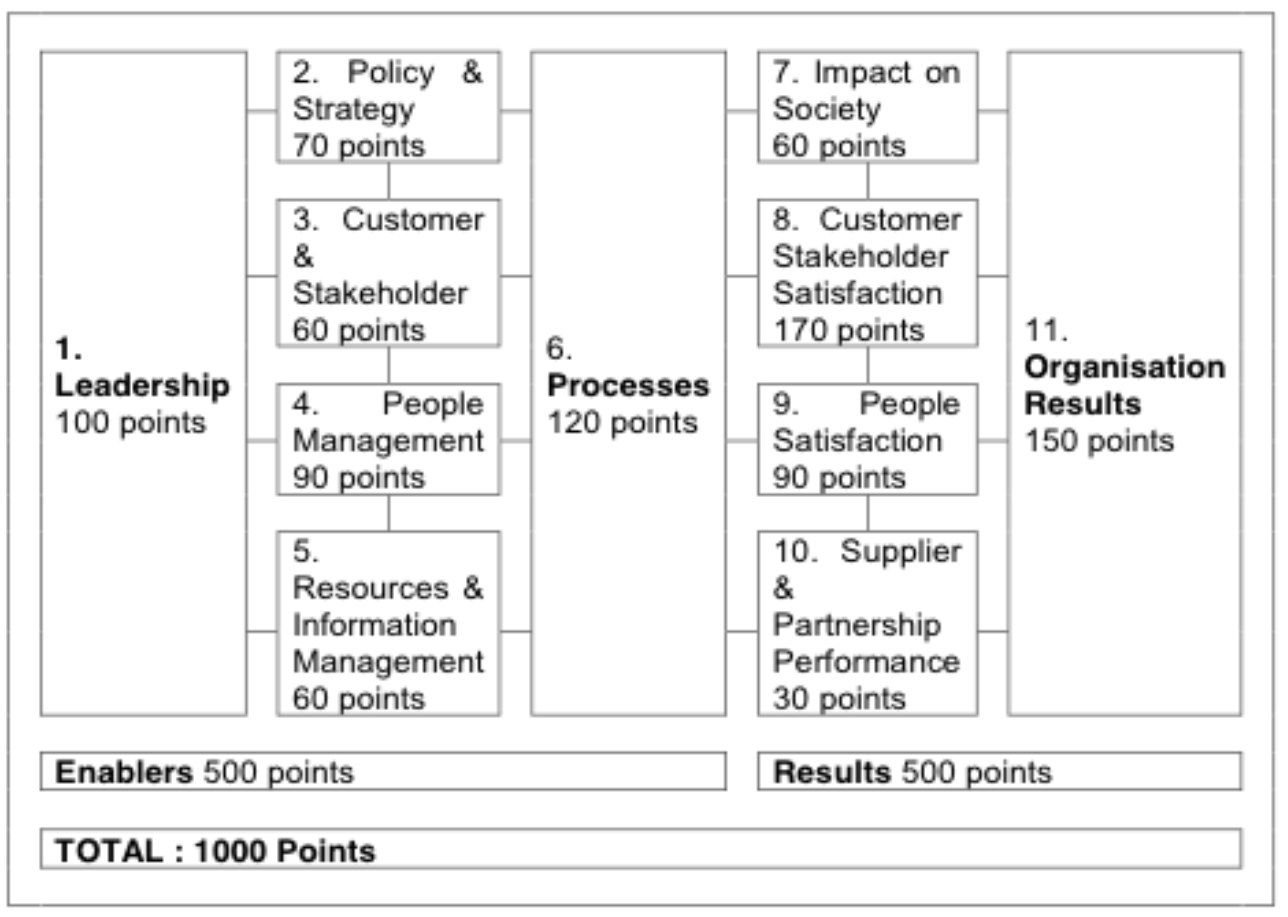

Source: Jantjes (2008: 22)

Citing van der Walt (2004), Jantjes (2008:22-23) states that the South African Excellence model can be used both in the private and public sector. Table 1 explains the concepts contained in the model. 
Table 1: Concepts in the Excellence Model

\begin{tabular}{|c|c|}
\hline Criteria & Aspects to measure \\
\hline Leadership & $\begin{array}{l}\text { The behaviour and actions of the executive team and how they } \\
\text { inspire, support and promote a culture of performance excellence. }\end{array}$ \\
\hline Policy \& Strategy & $\begin{array}{l}\text { How the organisation formulates, reviews and turns policy and } \\
\text { strategy into plans and actions. }\end{array}$ \\
\hline Customer Focus & $\begin{array}{l}\text { How the organisation determines customer requirements and } \\
\text { expectations, enhances relationship with customers, and } \\
\text { determines their satisfaction. }\end{array}$ \\
\hline People Management & $\begin{array}{l}\text { Whether or not the organisation realises that its most valued } \\
\text { assets are its employees and how it utilises them. Whether it } \\
\text { allows for the creativity to unfold and its employees to perform to } \\
\text { excellence. }\end{array}$ \\
\hline $\begin{array}{l}\text { Resources and } \\
\text { Information } \\
\text { Management }\end{array}$ & $\begin{array}{l}\text { Employees become effective and resourceful when they have } \\
\text { knowledge at their disposal. }\end{array}$ \\
\hline Processes & $\begin{array}{l}\text { How the organisation identifies, manages, reviews and improves } \\
\text { its processes. }\end{array}$ \\
\hline Impact on Society & $\begin{array}{l}\text { Whether or not the organisation takes the needs of the } \\
\text { communities around it into account (social involvement). }\end{array}$ \\
\hline $\begin{array}{l}\text { Customer } \\
\text { Satisfaction }\end{array}$ & What the organisation does to satisfy its customers. \\
\hline People Satisfaction & $\begin{array}{l}\text { Whether or not organisations realise that satisfied employees } \\
\text { result in satisfied customers. }\end{array}$ \\
\hline $\begin{array}{l}\text { Supplier } \\
\text { Partnership } \\
\text { Performance }\end{array}$ & $\begin{array}{l}\text { What the organisation is doing in regards to managing its } \\
\text { suppliers. }\end{array}$ \\
\hline Results & $\begin{array}{l}\text { Whether or not the organisation is achieving its planned objectives } \\
\text { and satisfying other stakeholders. }\end{array}$ \\
\hline
\end{tabular}

Source: Jantjes (2008: 23)

\subsection{Studies on PM in local government}

The study by Jantjes (2008) was focused mainly on organisational performance management in the City of Cape Town. The researcher intended to ascertain how the City of Cape Town went about implementing performance management. Furthermore, the researcher wanted to establish whether the implementation was consistent with the legislative provisions and, if there are gaps, what solutions can be offered. 
The researcher used evaluative research, guided by a qualitative philosophical approach, to analyse the existing performance management legislation and its implementation. The study was undertaken, through an empirical exercise, to evaluate textual documents of the organisation on performance management against the legislative framework for performance management to establish implementation gaps. The outcomes of this were triangulated against the outcomes of the interviews with participants, selected by way of a nonprobability sampling, a variation of snowball sampling (Jantjes 2008: 4-5).

Jantjes (2008: 77-78) found that in the city council of the City of Cape Town the individual performance management score cards were only compiled up to the level of the Section 57 managers. Even those scorecards for the Section 57 were not aligned to the City's Strategic Plan -the IDP. It was found that there was a policy attempt to link organisational performance to individual performance management in the City of Cape Town.

The study by Jantjes (2008: 16) considered a study by Brown (2002), which then led to the researcher to examine the study by Brown (2002). Brown's work is not only about individual performance, but it also usefully lays the ground for Jantjes's 2008 study. Brown's (2002) study focused on individual performance management in the City of Cape Town, and according to its findings, Individual Performance Management System (IPMS) increases staff accountability and thus improves customer satisfaction.

In a study of Performance Management in the Department of Education, Ravhura (2006) outlines the advantages and disadvantages of implementing Performance Management in an organisation. The study was intended, among other things, to theoretically identify the objectives, advantages and disadvantages of performance management.

The following advantages were highlighted by Ravhura (2006:14-15):

- Performance management promotes regular feedback between the employees and supervisors, thus encouraging employees to sustain good behaviour.

- The process of performance management begins with the agreement between the employee and the supervisor. This promotes the culture of participation in decision making, thus increased sense of ownership of any decision.

- By nature, performance management dictates frequent interaction between the employee and the supervisor. This can introduce and instil the highest senses of team spirit at the work place.

- Performance management can also contribute to improving communication amongst colleagues. It fosters the culture of consistent and structured communication. 
Ravhura's study also identifies some disadvantages which, if not carefully taken into account, can negatively affect the implementation of the performance system. Below are the disadvantages that Ravhura (2006:16) discloses with regards to performance management:

- It could block innovation under certain circumstances. Employees could feel trapped in the performance management agreed upon. This may make them refrain from contributing new ideas.

- In some cases, especially where management or leadership misuses the instrument; in fact if abused, it can demoralise good performing staff and generally discourage good performance.

- The instrument can also be misused to block the ambitions of employees.

The study concludes on a positive note, namely that without any doubt performance management is an essential ingredient for improved and successful service delivery (Ravhura, 2006:17). However, attention is drawn to the fact that, if no attempts are made to educate and familiarise the staff on the performance management policy and systems of the organisation, implementation could prove to be impossible (Rhavura, 2006:80).

Phala (2007) conducted a study on the institutionalisation of performance management, using the greater Sekhukhune District Municipality as a case study. The study was aimed at:

- Investigating whether or not the Greater Sekhukhune District Municipality has the structures in place, for the implementation of a performance management system;

- Assessing challenges which could be hindering the Greater Sekhukhune District municipality from successfully implementing the system;

- Establishing whether or not the Greater Sekhukhune District Municipality has systems or responses in place to overcome these challenges.

AS in the study by (Ravhura, 2006) described above, the researcher acknowledged that in order to ensure improved service delivery, performance management is a necessary cornerstone of the whole management effort (Phala, 2008:8). Part of the findings is that performance management is not known to the majority of staff in the Greater Sekhukhune District Municipality (Phala, 2007:74). This can be safely generalized to apply to most municipalities.

\subsection{Legislative framework on Performance Management}

Following the Reconstruction and Development Programme (RDP), underpinned by section 152 of the Constitution (RSAa, 1996, 49), which spells out the objects of local government, there have been a number of pieces of legislation passed confirming the declaration by the Thabo Mbeki-led government that South Africa will follow a developmental state approach. A developmental state is a 
state in which the government is focused on economic growth, which it strives to attain by intimately directing and controlling the macro and micro economic policies of a country (Marwala, 2009). This notion was by default further extended to municipalities as developmental local government.

In keeping with this notion of developmental local government, a number of pieces of legislation were passed to influence the macro and micro developmental environment, and to also support economic growth. These pieces of legislation include the Municipal Systems Act (RSA, 2000), the Municipal Finance Management Act (RSAa, 2003), Municipal Planning and Performance Management Regulations (RSAC, 2001) and others. The following section provides further details on the applicable policies and legislations within local government.

\subsubsection{Municipal Systems Act (Act 32 of 2000)}

Chapter 6 of the Municipal Systems Act (RSA, 2000: 51-52), read together with the subsequent amendment (RSA, 2003a), spells out the need for municipalities to develop performance management systems. A process of development and the establishment of the same, centred on the core democratic principle of public participation, is outlined. The MSA further directs that municipalities must establish a performance management system that:

- Is commensurate with the municipal resources;

- Promotes a culture of performance management amongst municipal leadership, staff and the community;

- Helps the municipality to administer its affairs economically, efficiently and effectively and in an accountable manner.

Section 41 of the Municipality System Act (Act 32 of 2000) sets out broadly the core components of a Performance Management Framework in a Municipality. These core components include:

- Appropriate key performance indicators with regards to priorities and objectives;

- Measurable performance targets with regard to each of those development priorities and objectives;

- Monitoring mechanisms of performance;

- Mechanisms of how to measure and review performance at least once per year;

- Performance improvement procedure;

- A process of regular reporting to the municipality and the public and appropriate organs of state. 
The need for an annual performance report is spelt out in section 46 of the MSA. Municipalities are expected to report on their performance publicly within one month after receiving an audit report. The annual report must be submitted to the MEC, AG and such other institutions as may be required by regulations.

The MSA further allocates the monitoring and evaluation responsibility to the MEC for local government and the Minister of Provincial and Local Government. MECs are expected to employ mechanisms to ensure that performance management is carried out in the municipalities as envisaged in the MSA.

The Municipal Systems Act has a direct bearing on the matters of performance management in local government. Thus even the regulations on Municipal Planning and Performance Management that I will discuss later on in this chapter are underpinned by it. Youth development as an integral part of a broader developmental duty of local government, must derive its expressions in terms of planning and performance management from and within this framework.

\subsubsection{Municipal Planning and Performance Regulations (R769 of 2005)}

These regulations, which came into being as a requirement of the Municipal Systems Act, are meant to breathe life into the provisions of the MSA particularly, Municipal Planning and Performance Management.

Chapter 3 of the regulations on Municipal Planning and Performance Management (RSA, 2001b: 9-16) further emphasises and clarifies the development of a PMS for municipalities. Most importantly, the regulations provide the basis for municipalities to develop key performance indicators. This basis could be used to guide the development of indicators for youth development.

\subsubsection{Municipal Performance Regulations For Municipal Managers And Managers Directly Accountable To Municipal Managers (R805 Of 2006)}

These regulations were passed with the aim of cascading performance management from the point of organisational performance management to individual performance management. The regulations provide for the specimens of the employment contracts and the Performance Agreements (RSA, 2006:3). Resulting from these regulations is the need to cascade PM even to lower positions such as the youth development managers and youth development coordinators.

Although the individual performance level will not be pursued here due to the limits of this study, it is important to provide a holistic picture for a contextual understanding. This is the reason why these regulations are alluded to. 


\subsubsection{The Municipal Finance Management Act (Act 56 of 2003)}

Section 52 (1) (c) (iii) (bb) of the Municipal Finance Management Act(MFMA) (RSA of 2003b: 68) provides for the Service Delivery and Budget Implementation Plans (SDBIP's), which link the section 46 of the Municipal Systems Act (RSA, 2000: 50) as amended to the performance management plans. The idea of SDBIPs is further elaborated upon in the MFMA circular number 13 (RSA, 2005).

In defining the Service Delivery and Budget implementation Plan, the MFMA (2003) states that it is a detailed plan approved by the Mayor of a Municipality in terms of section 53 (1) (c) (11), for implementing the delivery of Municipal services and their annual budgets and which must indicate: (a) projections for each month of revenue to be collected by source, and operational and capital expenditure by vote; (b) service delivery targets and performance indicators for each quarter; and (c) any other matters that may be prescribed and includes any revisions of such plan by the mayor in terms of section 54 (1) (c).

Section 53 (1)(c) (111) directs the mayor to take all reasonable steps to ensure that the annual performance agreements required from the municipal manager and the section 57 managers are entered into and are in (a) compliance with the MFMA and promote sound financial Management, and (b) are also be linked to the SDBIP and the measurable objectives approved with the budget.

Section 72 provides for the half-yearly assessment of the performance, by the accounting officer. It also provides for reporting.

The MFMA provides for the financial aspects of municipalities service delivery. The emphasis is more on rationalizing the budgets and the IDP. SDBIPs are the common ground for this purpose. Circular 13 of the MFMA serves the purpose of guiding the alignment of municipalities' strategic priorities, IDP and budget.

\subsubsection{The Public Administration Bill}

The Public Administration Bill as published by the Department of Public Service and Administration is mainly aimed at Public Service. The Bill proposes the repealing of the section providing for performance management. This also removes the component of community involvement in the performance management, thus weakening public accountability by the municipal council regarding its commitments.

Evidently as it stands, the planning and performance management framework in local government is much more superior in terms of compatibility with democratic principles compared to what is currently defined for the level of provincial governments and national government (de Visser and Steytler, 2009:782). 


\subsection{Performance Management Framework}

Performance management as a concept has been defined and explained at length earlier in this chapter. To complete the meaning of the concept performance management framework, it is necessary to define the concept of a framework.

Marriam-Webster's dictionary (accessed 28 June 2011) defines framework as "basic conceptual structure (as of ideas)". The Oxford Dictionary online (accessed 28 June 2011) defines framework as a "basic structure underling a system, concept or text." Therefore, a performance management framework should include broad concepts, definitions, processes, criteria and standards (Roos, 2009:31).

According to the Harrowgate Borough Council (2006:31), a performance management framework includes strategies, plans, policies, quality of life indicators and performance measures. The performance management framework has to consider stakeholders such as residents, councillors, management and others. Harrowgate Borough Council's approach is consistent with the approach advocated for in the introduction to performance management for local government in South Africa (Department of Provincial and local Government, 2001).

As indicated in section 41 of the Municipal Systems Act (RSA, 2000), the core components of performance management are too broad, and could have been confusing for municipalities, hence the guidelines developed by the Department of Local Government (Roos, 2009:31-32). Figure 5 illustrates the municipal level performance management framework as understood by the Department of Provincial and Local Government. 
Figure 5: The Municipal Performance Management Framework

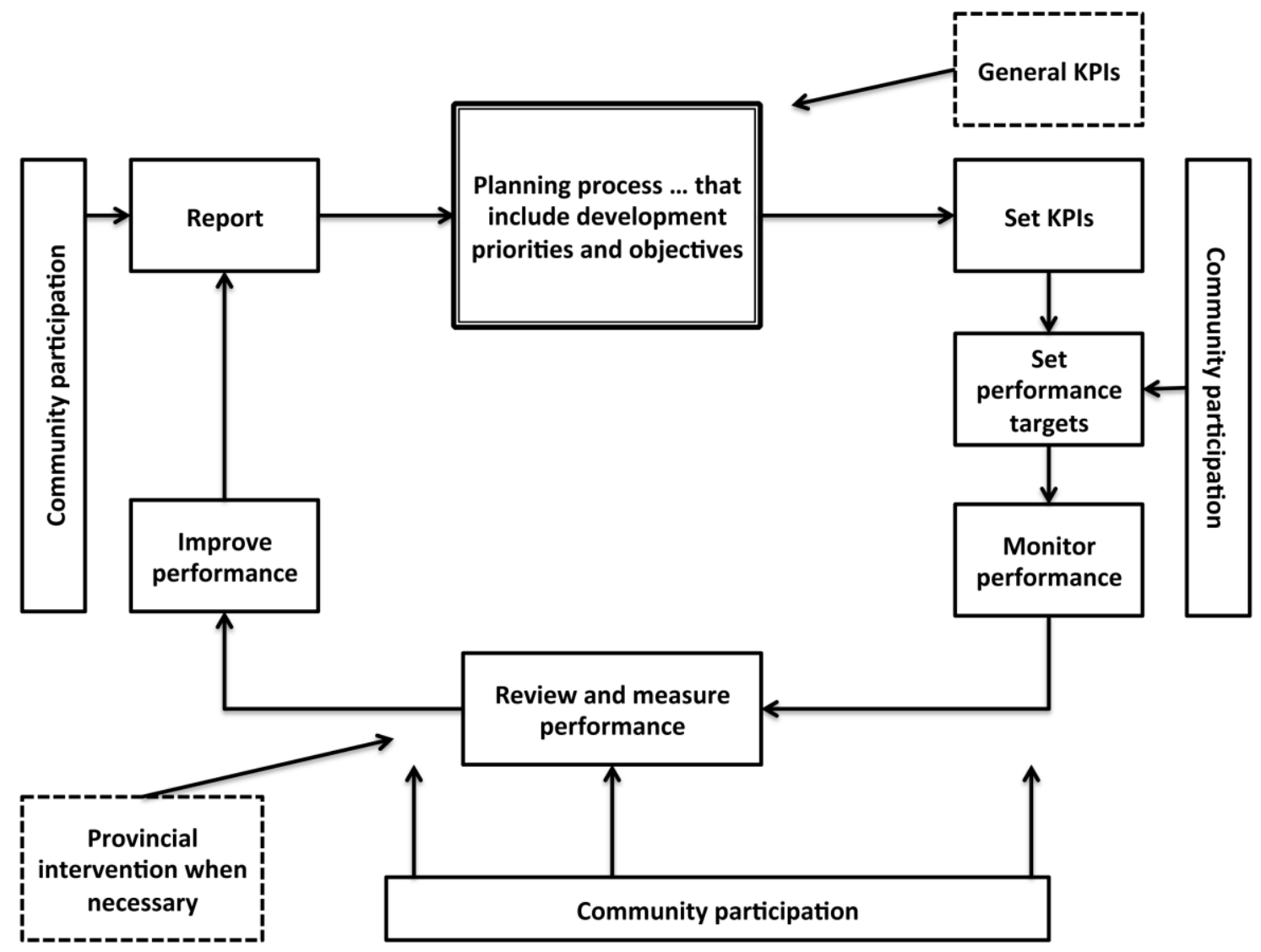

Source: Roos (2009:32)

\section{Performance Planning}

According to this diagram, the framework starts at the Planning (IDP) process. This process is prescribed in terms of Chapter 5 of the MSA (32 of 2000). The IDP process shall, on the basis of general or broad Key Performance Indicators, came up with development priorities and Development Objectives. At this stage either the IDP itself will contain Development Priorities and Objectives for youth development for the Municipal Area of demarcation, or the municipality shall come up with specifically a Localised Integrated Youth Development Strategy (as a sector plan).

\section{Key Performance Indicators and Targets}

From the above it is clear that the municipality sets the narrower KPIs. This is to be followed by defining the performance targets against these KPIs. The municipality shall for the purposes of youth development define narrower and SMART KPIs as well as the strategic objectives. Both of these shall be defined within the confines of the Key Development Areas for youth development defined later in Chapter 3 of this study.

Implementation and Monitoring

Subsequent to the above, the implementation and the monitoring of the targets commence. The major challenge is that most of the programmatic work that 
municipalities perform on youth development is not subjected to rigorous monitoring. This is mainly because the leadership of municipalities would be consumed by core municipal service delivery as outlined in Schedule 5 part B (RSA, 1996a).

\section{Performance Measurement}

After a specific period, either quarterly, half-yearly or annually, the municipalities engage with the activities of measurement and reviews of performance. The measurement of the targets on KPIs on youth development should have already been defined such that it allows for easy measurements. This would have been defined in terms of the inputs, outputs and outcomes. Expressions would have been decided upon quantitatively by percentages, volumes, sizes, numbers and by giving narrative descriptions of the targets. It would be important to ensure that there is sufficient youth buy-in at this stage.

\section{Performance Reporting}

According to the framework depicted above, this concludes with the compilation of performance report. For the purposes of logic, we indicate this stage before the stage of performance improvement. The report is required for submission at various forums as spelt out in the legislative framework. Moreover, it will be utilized to inform the performance planning process for the next period, and the circle is repeated over and over.

\section{Performance Improvement}

This activity can be undertaken during the mid-year review in order to improve the performance pace and to meet the set targets. The results of this measurement can be used as a benchmark for the following year. Given the reality about the dynamism and the volatility of the youth development environment, this stage could come in handy for municipalities to ascertain whether or not they are still within the developmental expectations. Youth involvement and participation are a necessity at this stage.

It is worth noting that throughout the framework process, there is conspicuous involvement of community participation, which is compliant with the democratic principle of people involvement in deciding on their development encompassed under Batho Pele.

In terms of Regulation 7(1) of the Municipal Planning and Performance Management Regulations (2001b: 9), a Municipal Performance Management System must, amongst other things, entail a framework that will describe how the process of performance management. This process must detail how planning, monitoring, measurement, review, reporting and improvement will be conducted. Figure 5 above illustrates these requirements. 
Furthermore, it must be recorded that the municipality performance framework is expected to address issues of role and role players, individual performance management process and the procedure to link IDP (planning) process with the performance management (Jantjes, 2008).

\subsection{Conclusions}

The literature on performance management clearly indicates that there are performance management systems in local government, in particular for municipalities. These PMSs cater for the individual and organisational PMS. The gap identified here is that the performance management system omits youth development performance management in municipalities. The models for measurement and assessment that have thus far been developed include the BSC and SMS and others. These might need to be modified to fit the performance management needs of youth development managers.

There are legislation and policies governing and regulating performance management in local government. This therefore allows for the development of a performance management system for youth development. 


\section{CHAPTER 3: YOUTH DEVELOPMENT IN SOUTH AFRICA}

\begin{abstract}
"...youth development, [is] a relatively new concept and perspectives on how delivery of services for young people was to occur, with their involvement and meaningful participation. However, it has to be said that the developmental challenges facing the youth, especially for those out of the mainstream of development, cannot be eradicated by a single sector of government."
\end{abstract}

(Hon. ME Tshabalala-Msimang, Minister in The Presidency, 2008).

\subsection{Introduction}

The concept of youth development is indeed a relatively new concept in the development discourse. This does not mean that there have never been any attempts to address the normative concerns with the broader youth development environment. The transition of a human being from childhood to adulthood has always been the most interesting component of human development. More often than not, the concept of youth development has been left to chance. Youth development has been viewed as a phenomenon of transforming youths into respectable, responsible and productive human beings. Historically, there would be no intentional and deliberate attempts or plans to direct this development. Thus many, including Christians, viewed the age of youth as the most challenging and the most volatile of all ages. For anybody to survive this age without being consumed by lust, temptations and mistakes was left to the forces of nature.

As in many free market economics, South African youths were for the entirety of the period before 1994 left to be survivalists in their own lives. However, after 1994 the RDP proposed for the first time the formal conceptualisation of youth development. This policy was informed by the historical disposition of youths in SA. The RDP was to be later adopted as government policy. The RDP covered mainly six thematic pillars for youth development. These are 1) job creation and capacity building including national youth service (NYS); 2) education and training, and restoration of hope in the future; 3) National Youth Service (NYS) dealing with youth alienation and unemployment; 4) establishment of a national institution to co-ordinate the youth service programme aimed at instilling national unity and social cohesion; 5) the establishment of a national youth council, a civil society organisation with the obligation of lobbying for the rights of the youth and to represent South Africa internationally; and finally; 6) the support of the South African government of the International Convention on the Rights of the Child (ANC, 1994: 73-74).

The RDP was followed by a number of policies. There was at first a National Youth Policy (NYP) 2000, then the National Youth Development Policy Framework 
(NYDFP) 2004-2007. These policies were to be later reinforced by the National Youth Commission Act, the formation of the Umsobomvu Youth Fund, the provincial Youth Commission Acts and recently, the National Youth Development Act and the National Youth Policy 2009-2014. These policies and laws, amongst others, guided the evolution of youth development in South Africa and the approaches to the same. Furthermore, these policies provided for the structures of youth development. A more concrete definition of youth and youth development also emerged from this framework.

This chapter will define youth and youth development within the context of South Africa. It also provides a brief narrative of South Africa's history regarding the evolution of youth development. The researcher also explains the paradigm shifts on youth development approaches in South Afrfica since the RDP era. Significant studies on the subject of youth development are summarised and finally the legislation and policies governing youth development are explored to the level of local government.

\subsection{Defining Youth and Youth Development in South Africa}

In order to sufficiently address the subject of youth development it is necessary to start by defining what is meant by the term 'youth', especially in South Africa.

\subsubsection{Defining Youth in South Africa}

In order to properly define youth development, it is logical that the researcher must first define the concept youth as understood in South Africa in particular and the world in general. It is generally agreed by many authors that there have always been many variations as to which ages are to be considered as referring to youth. Western countries see youths as young people between the ages of 18 and 35, whereas the United Nations suggests the ages between 15 and 24 .

South Africa is not immune from this confusion. The government departments themselves have had varying definitions of the concept of youth. The National Youth Commission agreed to define youths as persons between the ages of 15 and 35 years, based on the arguments that the needs and life expectations of a 14 year-old person are not the same as those of someone who is 35 years old, and more so between cohorts i.e. the needs of the age group 14-24 are different from those of the 25-34 age group. Thus it is accepted that these persons are further categorised into youth age cohorts (Maas et al. 2007:5-9).

The South African Status of Youth Report (2005: 17) conceives the term youth as a socially constructed concept with a definition that varies from country to country and also across the sectors within the same country. This assertion is also confirmed by Potgieter (2007: 13-14). The definition is dependent on cultural, socio-economic and political factors. This implies that because of the different make-up of the societies, especially in terms of culture, socio-economics and 
political orientation, there are bound to be varying definitions in different countries. In South Africa, for example, there are further variations of the definition. This is because the make-up of South African communities differs from one community to another and as South Africa has diverse communities.

The view that there are many definitions of the term youth is further confirmed in RSA (2008b: 5-6) in the National Youth Policy. According to these researchers, because of the various policies by various government departments, there are a variety of definitions of the concept youth in South Africa. Some policies define youth as persons between the ages of 15 and 28 years, whilst others define the same concept as referring to persons between the ages of 14 and 35 years.

The National Youth Policy (RSA, 2008b) states that the term youth is "used inclusively to refer to young people as those falling within the age group of 14 to 35 years. This is based on the mandate of the National Youth Commission Act of 1996 and the National Youth Policy of 2000. This inclusive approach takes into account both historical and present-day conditions. Although much has changed for young people since the advent of democracy in 1994, the motivation for 35 years as the upper age limit of the youth has not yet changed. This is due to the fact that historical imbalances in the country have not yet been fully addressed.

The above definition of the term youth is consistent with the definition contained in the African Youth Charter, which defines youths as those people between the ages of 15 and 35 years (AU, 2006). Although the latter definition excludes the 14year-olds, the difference is insignificant. RSA (2008b: 5-6), confirms this definition as indeed, espoused in the African Youth Charter.

The Youth Development Strategy for Local Government (2007:6-13) by South African Local Government Association and the National Youth Development Agency Act (RSA, 2008a: 4) reaffirms the definition accepted earlier in South Africa that 'youth' means persons between 14 and 35 years. The Draft Youth Development Strategy for Local Government by the Department of Cooperative Governance and Traditional Affairs (CoGTA) reaffirms this definition as referring to young people between the ages of 14 and 35 (CoGTA, 2010; 32).

It is important at this stage to note that the most popular definition for the term youth is that which means young persons between the ages of 14 and 35 years.

Furthermore, Evaratt (2000: 22-23 as quoted by Maas et al. 2007: 5) and Morrow, Panday and Richter (2005: 17) agree with the assertion by O'Higgins (1997: 4), that the life experiences, contexts and needs of a 14-year-old are radically different from the needs of a 35-year-old. Thus SALGA (2007: 7-9) takes this definition further by arguing that within the same age group there are three 
different cohorts with different issues, different challenges, different concerns as well as different developmental needs. These age cohorts are depicted as Category 1: The Teenage Group (14-17 years), Category 2: Young Adults (18-24 years) and finally, Category 3: Young Adults (25-35).

Even though COGTA(2010: 32) suggests that the breakdown of this age group could be arranged differently from the breakdown by SALGA, CoGTA goes further to suggest that specific yet different interventions will be required for each cohort. For example, interventions for people aged between 15 and 19 years could focus on education and training; for those in the 20-24 years age group, could focus on the transition from school to work, and for aged those 25 to 35 years it could focus on training, learnership and employment. Furthermore, according to SALGA (2007: 10-11), 'youth' is defined in terms of the youth segments as illustrated in Table 2.

Table 2: Youth Segmentation

\begin{tabular}{|c|c|}
\hline Youth Segment & Description of Youth Segment \\
\hline School-Going Youth & $\begin{array}{l}\text { Young people in Institutions of learning both at high } \\
\text { and tertiary institutions. They present special needs } \\
\text { such as for information in general, life challenges, } \\
\text { need for resources to pursue further education, need } \\
\text { to understand employment trends or economic } \\
\text { opportunities after schooling. }\end{array}$ \\
\hline Unemployed Youth & $\begin{array}{l}\text { This consists of two broad categories } \\
\text { Youth people who have not completed their } \\
\text { education to be level initially planned (i.e. } \\
\text { young people who are out of school and not } \\
\text { in any employment) and are usually } \\
\text { subjected to under-employment and chronic } \\
\text { unemployment as some of them are likely } \\
\text { not to be employed or involved in any } \\
\text { economic activity that is income generating } \\
\text { in their lives if no interventions is made; } \\
\text { Young people who have acquired a } \\
\text { specialized skill but are unable to access } \\
\text { employment. Generally known as } \\
\text { unemployed graduates. } \\
\text { The experience of unemployment can bring with it a } \\
\text { number of social ills including participation in crime, } \\
\text { drug and alcohol abuse and the loss of confidence } \\
\text { and interest to participate in meaningful of broader } \\
\text { society. } \\
\text { ASGISA's initiative and JIPSA intervention are thus } \\
\text { aimed at improving the employability of these young } \\
\text { people. }\end{array}$ \\
\hline Employed Youth & $\begin{array}{l}\text { These are the young people who are involved in the } \\
\text { economy via formal employment. Entrepreneurial } \\
\text { activities or in learnership, internship and youth } \\
\text { service programmes. }\end{array}$ \\
\hline Youth in conflict with the Law & $\begin{array}{l}\text { These are young men and women who are trapped in } \\
\text { the cycle of crime some of which is violent and are in } \\
\text { and out of prison. In some instances this is the result } \\
\text { of a breakdown in social institutions such as family } \\
\text { and schools. Abuse of alcohol and drugs becomes an } \\
\text { escape that exacerbates the problem and creates } \\
\text { young habitual criminals the society cannot afford.. }\end{array}$ \\
\hline $\begin{array}{l}\text { Young men and women } \\
\text { heading households }\end{array}$ & $\begin{array}{l}\text { In most cases these are young men and women who } \\
\text { are orphans as a result of HIV and AIDS-related } \\
\text { diseases and other social problems and they find } \\
\text { themselves looking after siblings. Although this is not } \\
\text { a new phenomenon in our country, as migrant labour } \\
\text { systems did create this group of young people but the } \\
\text { magnitude is alarming with HIV and AIDS and other } \\
\text { social challenges. If these young people are not } \\
\text { attended to as a special group, long term impact with } \\
\text { be unbearable. }\end{array}$ \\
\hline
\end{tabular}

\begin{tabular}{|l|l|}
\hline Youth Segment & Description of Youth Segment \\
\hline $\begin{array}{l}\text { HIV and AIDS-infected and } \\
\text { affected youths }\end{array}$ & $\begin{array}{l}\text { Young people who are affected and those living with } \\
\text { HIV and AIDS. In some instances, those who are } \\
\text { affected are looking after family members, mainly } \\
\text { parents, living with HIV and AIDS. A slightly different } \\
\text { group from the previous one because adults are still } \\
\text { alive but too sick to assume their parental } \\
\text { responsibilities. }\end{array}$ \\
\hline $\begin{array}{l}\text { Young people living and } \\
\text { working on the streets. }\end{array}$ & $\begin{array}{l}\text { Forced out of their families and community by } \\
\text { whatever conditions, they have opted to live and work } \\
\text { in the streets. They are generally subjected to } \\
\text { harassment, brutality and sub-human living } \\
\text { conditions. }\end{array}$ \\
\hline $\begin{array}{l}\text { Rural and urban young men } \\
\text { and Women. }\end{array}$ & $\begin{array}{l}\text { Young women and men in rural areas are often more } \\
\text { disadvantaged than those who live in urban settings. } \\
\text { They have less access to services and facilities and } \\
\text { the opportunities for employment are far less than in } \\
\text { urban areas. Dropping out of school to join the army, } \\
\text { or unemployed youths who have no hope of ever } \\
\text { working in their lives is not uncommon in this group. } \\
\text { Where one is born somehow dictates life destiny and } \\
\text { this becomes a vicious cycle that must be broken. }\end{array}$ \\
\hline $\begin{array}{l}\text { Young men and women } \\
\text { trapped in drug and alcohol } \\
\text { abuse }\end{array}$ & $\begin{array}{l}\text { At times, being victims of specific circumstances and } \\
\text { realities over which they have no or a little control, } \\
\text { these young men and women are fund trapped in a } \\
\text { vicious cycle of drug and alcohol abuse. }\end{array}$ \\
\hline & $\begin{array}{l}\text { Finding themselves in the midst of a vulnerable group, } \\
\text { they become even more vulnerable given the stigma } \\
\text { associated with some form of disability. }\end{array}$ \\
\hline
\end{tabular}

Source: Adapted from the Youth Development Strategy (SALGA, 2007) 
The NYP (2008) states that marginalised and excluded groups of young people require specialised interventions. It recognises that there may be multiple dimensions of youth groups, but specifically identifies special groups as:

- Young women, who suffer the highest levels of under-education, lack of skills, unemployment, HIV and AIDS infection, victims of violence and abuse;

- Youths with disabilities, who are typically excluded, suffer high levels of under-education, unemployment and lack of skills and access to opportunities;

- Unemployed youths, who suffer from insecurities such as low-selfesteem resulting from the condition of poverty. Unemployed youth are vulnerable to crime, drug and alcohol abuse and poor health. They also tend to have minimal participation rates in civil society activities;

- School-aged-out-of-school youths, who are more likely to engage in high-risk behaviours, such as crime, drugs and alcohol abuse, rape, violence and exploitation;

- Youths in rural areas, who typically have to struggle with the low availability of services and facilities as well as opportunities. Additionally, the high levels of youth migration to urban areas exacerbate the underdevelopment of rural areas;

- Youth at risk: youths living with HIV \& AIDS; the prevalence rates of HIV and AIDS among youth are a serious cause for concern. Youth are powerful agents that can decrease the prevalence of HIV/AIDS. There is a need to care for those infected and affected by HIV and AIDS.

- Youths heading households and who are at a greater risk of abuse, exploitation and dropping out of school, thus being excluded from services such as school-feeding programmes, school health programmes and relevant initiatives;

- Youths in conflict with the law. The rate of youths in conflict with the law is worryingly high. Offences by youths seem to be on the increase;

- Youths abusing dependency-creating substances. There is a need to have interventions that target youths who already have the problem of abusing dependency-creating substances as well has having measures in place to reduce the likelihood of having youths falling into this problem.

It is therefore generally acceptable that the term 'youth' in South Africa should mean persons between the ages of 14 and 35 years. This age group should be 
divided into three cohorts namely; 14 to 17 years, 18 to 24 years and 25 to 35 years (SALGA, 2007). The first cohort is the teenage group, the second is the youth group and the third cohort is the young adults. Care is taken to consider the respective segments for youth development.

\subsubsection{Defining Youth Development}

The Reconstruction and Development Programme (1994: 73) defined youth development as '[the development approach] which must focus on education and training, job creation, and enabling young people to realise their full potential and to participate fully in the society and the future. It must restore the hope of our youth in the future, and in their capacity to channel their resourcefulness and energy into reconstruction and development.'

The National Youth Development Policy Framework, (2002: 3) provides an underpinning for a definition of youth development when it asserts that:

We celebrate the roles of young women and men in South Africa and their contribution to the reconstruction and development of their communities and the country. We recognise the contributions young people make to our society and build upon the imagination, energy, vibrancy and talents of all young women and men. These contributions need to be enhanced through initiatives that will bring about personal development for young people and their organisations.

According to Maas et al. (2007: 8 citing Richards, 1997), youth development is about transforming the situation of the youth from being dependent to that of being independent. Accordingly, it is about encouraging and enabling the youth to find their place in the society as independent and functional adults. It should therefore be the aim of youth development to enable the participation of the youth in the economy, society and politics. According to these researchers, youth development is about guiding the transformation of a human being from childhood to adulthood.

Pittman et al. (as cited by Richter et al. 2005) argue that youth development should be understood as an ongoing process in which all youths are engaged in an attempt to (1) meet their basic needs to be safe, feel cared for, valued, be useful and be spiritually grounded, and (2) build skills and competencies that allow them to function and contribute in their daily lives. To achieve this successfully, youth development has to follow an integrated approach which recognises the assets and strengths of young people rather than focusing only on their problems and limitations.

The definition in RSA (2008a: 11-12) of the concept of youth work agrees with the idea of a guided process or deliberate intervention of a young person to adulthood. However, they also argue that the focus is more on groups than 
individuals. According to these researchers, the development of individual young persons is the focal point for youth work.

In the National Youth Development Strategy 2007-2012 (2007: 4) of the department of social development, youth development is defined as "a positive process which prepares and facilitates the smooth transition from childhood to adulthood through a coordinated, progressive series of activities and experiences which help young people to become socially, morally, emotionally, physically and cognitively competent. Positive youth development addresses the broader developmental needs of youth, in contrast to deficit - based models, which focus solely on youth problems." In this definition, the notion of transition from childhood to adulthood is emphasized. This definition further suggests that in that transition there is intentional and deliberate intervention to influence the process and the outcome.

The National Youth Policy 2009-2013 (2008b: 10) (CoGTA: 2010: vii) defines youth development as:

an intentional comprehensive approach that provides space, opportunities and support for young people to maximise their individual and collective creative energies for personal development as well as development of the broader society of which they are an integral part.

In essence, this definition suggests that youth development is about creating a conducive environment for the development of young persons, individually or collectively to enable them to effectively contribute to the development of the general society.

From the literature reviewed above, it becomes apparent that youth development can be viewed as both the process and the outcome. From the process point of view, it is about equipping a young person to face the multiple yet inevitable challenges of adolescence to adulthood. It is about building a future cadre through structured interventions to help them navigate through the challenges of real life. From the outcome point of view, there are some tangible outcomes anticipated at the end of interventions aimed at youth development. These could include empowering the youth, among others, financially, psychologically and socially. It is also clear that the most accepted and up-todate definition of youth development, is the one advocated for in the National Youth Development Policy 2009-2013 (2008b: 10).

\subsection{Evolution of Youth Development in South Africa}

It would be an omission to describe what youth development is today without referencing the socio-political dynamics and history that gave rise to it. One of the respected researchers on youth development, Seekings (1996:104), has 
stated that youth is a political construct of the 1980s, because young black people were mainly described as "shock troops" or "foot soldiers" in the struggle for liberation. This history of the youth provides a fascinating account and also elucidates the state of youth development today.

Since the conception of the struggle against apartheid and all its forms of oppression, the youth of South Africa have always been at the leading edge of the revolts and struggles. As a motive force for the liberation struggle, they must have always been motivated by the issues of oppression which had a direct impact on their development. According to Seekings (1996:104), young Black South Africans in their struggle for political change agitated against the apartheid state by boycotting classes, demonstrating, building barricades and fighting against the South African police and army. As Everatt (2000) posits, these youths took on the police and army with half bricks and petrol bombs, resulting in representations of them as militant and active. After the 1976 uprisings the youth of South Africa became unrelenting in their pursuit for democracy in South Africa. They rejected what they saw as an education system that was designed to keep black youths subjugated to an oppressive apartheid system.

Young people's ability to mass mobilise during the transition period became useful when the negotiations for democracy were not going smoothly. However, their role in negotiating the transition was later sidelined, because they were regarded as incapable of negotiating and prone to use violence. This view of the youth was perpetuated by politicians, the media and in certain instances by researchers. The youth at that time became known as the "lost generation." This culminated in many young people who had become members of political organisations moving away from these organisations. Furthermore, these developments inevitably led to a deflation of the liberatory views of the young lions within the democratic movement. Thus, the negotiation process produced a 'moral panic' created by mainstream media, politicians and researchers who demonised young black youths, and produced a 'youth problem' (Everatt, 2000:9; Samara, 2011:59).

Amidst the negative perceptions of youth, particularly male black youths, the Joint Enrichment Project and the National Youth Development Forum (NYDF), both of which were formed to be strong lobbyists for youth issues challenged the tag 'lost generation' attached to the youth. The JEP survey 'Growing up Tough: A national survey of South African youth' researched different dimensions of marginalisation, reviewing international literature and proposing policy and programmatic interventions. It showed that few young people embraced violence or became especially alienated from the political transition. Furthermore, where black youths were at risk of marginalisation, the research showed that other racial youth groups were also at risk of marginalisation. The JEP/NYDF research led an explicit national move away from the discourse of a 
'lost generation' to one of 'marginalised youth,' thereby implicating social structures rather than the youths themselves. This was a watershed moment in youth development history, which will be discussed in more detail in subsequent sections (Seekings, 1996; Everatt, 2004; Potgieter, 2004).

Despite the concerns that the idea of youth development was not sufficiently addressed, it was nonetheless formally captured as a government programme for the first time in the RDP (ANC, 1994: 73-74). This was later crystallised into the national youth policy 2000, and later the National Youth Development Policy Framework 200-2007. The assumption has always been that youth development is best addressed at the national and provincial levels. This can be seen in the structures of the National Youth Commission, which were only replicated at the provincial level, and the Umsobomvu Youth Fund, which is located in the Department of Labour with satellite offices in some dense urban areas of the provinces.

Everratt (2000) argues that the minimal consideration and appearance of youth needs in the Reconstruction and Development Programme was a result of the youth development sector's in-fighting. Much of the contention within the youth sector was the proposed youth ministry that would be created as a reward for the valiant youths during the struggle. As much as some within the youth sector were for the youth ministry, many others were opposed to it, fearing that it would be relegated to a junior ministry and be under-resourced. The major argument against a youth ministry was that youth development should be treated as an integral programme to all the key departments of government, and not as a single and isolated issue. The argument for a youth ministry mutated into one of arguing for desk officers in key ministries. This argument failed because those who advocated for a youth desk did not have adequate knowledge of how government functioned in terms of governance and institutional arrangements. The lack of specific, sector-based demands for the youth was also a result of the youth sector's failure to rise above political squabbling. Thus a strong youth development agenda was not crafted into policy during this process. Everatt states that the period from the mid-1990s to the end of that decade was a failure for the youth sector.

Since 1994 South Africa's youth development has undergone major restructuring with an emphasis on putting in place institutions and strategies aimed at eliminating historically engineered inequalities and the empowerment of all youths to actively participate in the mainstream economy. This also led to the formation of the UYF to address the mandate of job creation and enterprise development and support, as well as the establishment of the NYC with the mandate of mainly policy, lobbying and advocacy. 
From the onset, the conception and inception of NYC and UmsobomvU Youth Fund as parallel institutions received mixed responses from a cross-section of the interested parties. Policy and decision makers as well as commentators contended that the nature and structures of their arrangements created administrative tensions which stifled their ability to optimally render their mandated services. The existing body of literature confirms that their performance was marginal, as exemplified by low rates of youth participation in economic activities.

Parallel to the establishment of the NYC and the UYF, civil society organised itself into the South African Youth Council (SAYC) and the Youth Development Network (YDN) (Youth Development Network, 2002).

The $23^{\text {rd }}$ National Congress of the African National Congress Youth League (ANC YL, 2008: 25-26) endorsed the resolution taken at the ANC National Conference in Polokwane (ANC, 2007: 16) that the merger between the Umsobomvu Youth Fund (UYF) and the National Youth Commission (NYC) must merge into a single youth development institution, i.e. the National Youth Development Agency (ANCYL, 2008: 13).

In pursuance of consolidated youth establishment, the government undertook a policy review that resulted in the merger of the two institutions. This culminated in the promulgation of the National Youth Development Agency Act No. 54 of 2008, which establishes the National Youth development Agency (NYDA). The Act further mandates the Agency to develop guidelines for the implementation of an integrated national youth development policy that would serve as a key driver for all youth development activities within the country.

There are market differences in patterns of youth development in South Africa before and after 1994. Prior to the advent of democracy in 1994, youth development and the participation of youth were conditioned by the segregationist policies of the then apartheid state. During this period we see South African youths' historic participation in moulding the country. Significant in this period is Hendrick Verwoerd the progenitor and practitioner of grand apartheid, who at the age of 33 years conceptualized and launched his vision of apartheid. Today all South Africans are reaping both the bitter and sweet fruits of that legacy. However, the bitterness or the sweetness depends on one's location in the mainstream economy.

Many interventions have been implemented since 1994 with a positive impact on youth development in general. These include:

- The establishment of the National Youth Commission (NYC) in 1996 through the NYC Act (19 of 1996) tasked with developing integrated National Youth Policy; 
- The adoption of a policy framework for youth development focusing on economic participation, social mobilization, capacity building as well as advocacy, justice and safety;

- The establishment of Umsobomvu Youth fund (UYF) with a capitalization of R1 billion (and this partly as a consequence of NYC's work);

- Establishment of Provincial Youth Commission, the South African Youth Council, and the Youth Desk in the Presidency;

- The design and implementation of the National Youth service (NYS) programme; and

- Recently the merger of the UYF and the NYC to form the National Youth development Agency (NYDA) with a mandate to forge ahead with the quest for youth development which, now as encapsulated in the NYP, must focus on economic participation, education, health and wellbeing, social cohesion and civic participation, the National Youth Service Programme as well as professionalization of youth work.

\subsection{Approaches to youth development in South Africa}

The discussion of the youth development framework takes its cue from the definition of youth development outlined above. The term 'youth development' is defined as:

An intentional comprehensive approach that provides space, opportunities and support for young people to maximise their individual and collective creative energies for personal development as well as development of the broader society of which they are an integral part" Everatt(2000:10).

During the period of developing the Reconstruction and Development Programme, the discourse of 'integrated youth development' emerged. As Everatt (2000:10) describes it: integrated youth development emerged as a concept that sought to counter and debunk the notion of a lost generation. He states 'integrated youth development entailed designing programmes that took youth in their own context and sought to provide for various needs (such as health, education, skills training, life skills and others) in a single programme' (ibid.)

Thus, an integrated youth development paradigm emerged against the stigmatising problem-reduction strategy. The latter, which aimed to fix singular youth problems, was criticised for its disjointed and fragmented approach towards enhancing young people's lives. In the 1990s there was a deliberate paradigm shift from perceiving the youth as a problem to seeing youth as an age category rich in opportunities and treasure to be exploited. In the new approach, youths were to be seen as virgin and potential mine lands, rich with minerals of all kinds, ready to be exploited. The new youth development 
approach in South Africa was to be based on the following principles (UYF, 2005: 19-22):

- Holistic development of young people. Young people are to be exposed to an array of skills and capabilities, i.e. emotional and socioeconomic. This meant the development of a balanced human being who can contribute to positive human development.

- Youth diversity and redress. Due to the political and economic history of the peoples of South Africa, the heterogeneous cultures, socioeconomic backgrounds and upbringing, the needs and aspirations of the youths of South Africa are not the same. This calls for graded interventions to youth development challenges.

- Life cycle approach. This relates to the transition from childhood to adulthood. Beginning from childhood development right through to funding than through parenting as young parents.

- Youth development as part of community development is based on the notion that youth development is not an isolated phenomenon; it fits into the whole concept of community development.

- Youth development and inclusivity. This refers to the involvement and participation by the youth in decision-making processes. This is for both their interests and rights.

- A transparent, accessible and sustainable response. This refers to the development interventions responding to the needs of the current generation without jeopardizing the prospects of the future generation.

According to the State of the Youth Report (UYF, 2005), in South Africa youth development is impacted upon by the following factors:

- Education

- Labour market participation

- Education and work

- Marital status

- Sexual behaviour

- Pregnancy

- Financial and residential Independence

- Perceptions of adulthood.

These factors were derived from the respondents' answers to the questionnaire administered by the researchers who compiled the State of the Youth Report 2005. The State of the Youth report confirms that the only basis upon which an evaluation of the status of the youth of South Africa can be carried out is the broad policy and programmes guidelines, (UYF, 2005). There were no plans for youth development at all levels in South Africa. Even today, there is no convincing evidence of youth development plans or strategies in South Africa. 
The literature survey conducted for this study confirms that there has been very minimal planning for youth development in South Africa. This is even more so in local government. A study by SALGA (Mallane,2011) on the involvement by municipalities in relation to equity and various other areas (i.e. HIV/AIDS; gender equality; youth development as well disability) was conducted in 2010 . The study sampled 88 out of 283 municipalities from all nine provinces. Three categories (metro, district and local municipalities) were included in the sample. Only 76 municipalities responded effectively to the survey. The study revealed that 59 out of 76 participating municipalities had included youth development in their IDPs, sector plans, strategies, projects as well as in the SDBIPs. Furthermore, the study reveals that only 38 municipalities included youth development considerations in their scorecards. Should this anecdotal information be anything to go by, this will mean municipalities are beginning to include the matters of youth development in their plans.

The question is whether this inclusion means inclusion in the mainstream or at the periphery. It would appear that there are still no specific and particular youth development strategies developed with the youths in terms of the democratic principle of participation. At the national and provincial levels, the role of youth development plans or strategies seems to be confused with policies.

\subsection{Studies on Youth Development in South Africa}

As indicated earlier in the report, there are not many studies conducted on youth development, especially in the context of local government. In this regard only the studies mentioned below were reviewed. These studies have some relevance to the study.

\subsubsection{Status of Youth Work in South Africa}

The department of Social Development commissioned a study called 'The Status of Youth Development Practice in South Africa' (RSA, 2009). The researchers employed numerous tools to resolve the research questions. They used semistructured interviews, focus group discussions, literature reviews and primary surveys. The methodology was more of a mixed approach, since they employed both qualitative and quantitative methods.

The study's focus was on youth work. A distinction was drawn between the youth work and youth development practices. According to these researchers, the two concepts are interdependent, but there is some distinction. Youth work should be seen as an integral part of youth development in general. Youth work focuses on the individuals and youth development of the youth groups. The study found that there is a need to deal with the professionalization of youth work, define the unit standard for the youth workers, determine how to recognize prior learning and experience, and finally the need to register youth workers as professionals. 
The study found that youth work is not properly structured and youth organisations are not effective as agents of change. Furthermore, the study revealed that most youth workers are not dedicated to their work because of poor remuneration. The general view is that youth work needs to be professionalized to attract and retain appropriate youth workers. According to this study, this will in turn improve service delivery. However, the researchers also argue that professionalisation can only occur when effective performance management is enforced.

\subsubsection{Evaluation of Youth Development Programme at Swartland Municipality}

Sogwagwa (2010) conducted a programme evaluation study of a youth development programme in Swartland Municipality. The main aim of the study was to evaluate whether the planned outputs of the programme were implemented and achieved as planned. The researcher intended to identify the gaps impeding the achievement of the objectives of the programme. The study, although not conducted within Nkangala, remains relevant because it addresses programme evaluation within a municipality.

To achieve this, the researcher considered the contents of the Memorandum of Agreement (MOA) signed between the municipality and Umsobomvu Youth Fund, the monthly plans of the Youth Advisory Centre (YAC) as well as the annual report of the Swartland Municipality. He highlighted that the Swartland Municipality Annual Report does not cover the achievements in the Youth Advisory Centre's report. The researcher also interviewed the staff from the YAC and the municipal staff.

The researcher found that there was an apparent disagreement in the responses given by the participants in the interview and the facts presented in the reports. He found that the targets contained in the documents, i.e. MoA, YAC, monthly plans and Swartland Annual Plan were different from each other, and that the documents were not properly aligned. Furthermore, he found that the programme did not realize most of the targets but missed others by small margins.

\subsubsection{Integrating Youth Development in Free State}

The Human Science Research Council in Bloemfontein conducted a study entitled 'Integrating Youth Development in the Free State' (HSRC, 2004). The study was aimed at determining the extent and the type of integration in the spheres of government, in relation to youth development so as to determine the constraints and the opportunities for such integration. The study also recommended strategies and operational principles that would facilitate integrated youth development across the spheres. 
The researchers focused on the practices of the government spheres and the programmes run by these institutions to promote youth development and address youth issues. They administered a survey questionnaire to assist in finding answers to their research questions. These questionnaires were administered to the officials of the provincial departments and to the municipalities of the Free State.

Of direct relevance to the study are the findings pertaining to municipalities. These findings demonstrate the gaps that can be generated in local government. They found that most (80\%) municipalities did not implement youth development programmes due to budget constraints. They also regard youth development as the competency of the provincial government and not of the municipalities. Seventy per cent (70\%) of the municipalities had established youth units and had employed at least one staff member. Only 10\% of municipalities had capacitated their youth development employees.

\subsubsection{South African Youth Context: The Younger Generation}

Recently, the NYDA commissioned a study which would inform the President's State of Youth Report 2012. According to this report (NYDA, 2001), young people under the age of 35 years account for $77 \%$ of the population in South Africa. Youths between the ages of 14 years and 35 years account for $41 \%$ of the population. The age group was estimated to constitute 20.5 million of the total national population estimated at 50 million people. The population group 14 to 35 years has been growing at an average rate of 1.27 \% per annum since 2005 . In essence, this suggests that the South African population is getting younger. At the same time fertility declined to $2.69 \%$ in 2007 and mortality was fuelled by HIV/AIDS deaths. Life expectancy is also declining, and it is currently estimated to be below 40 years in most provinces. All these factors lead to a bulging population. Should the statistics remain in the same trend, the South African population structure will have a youth bulge. This means that in 20 years time the current youth generation will dominate our population as the economically active, i.e. as middle-aged people. The following figure illustrates the population dynamics explained above. This predicted phenomenon leads to a demographic dividend scenario, which means an increase in the population share of the economically active strata of the population, which could result in an accelerated economic growth. 
Figure 6: Population Pyramids, 2007 and 2037

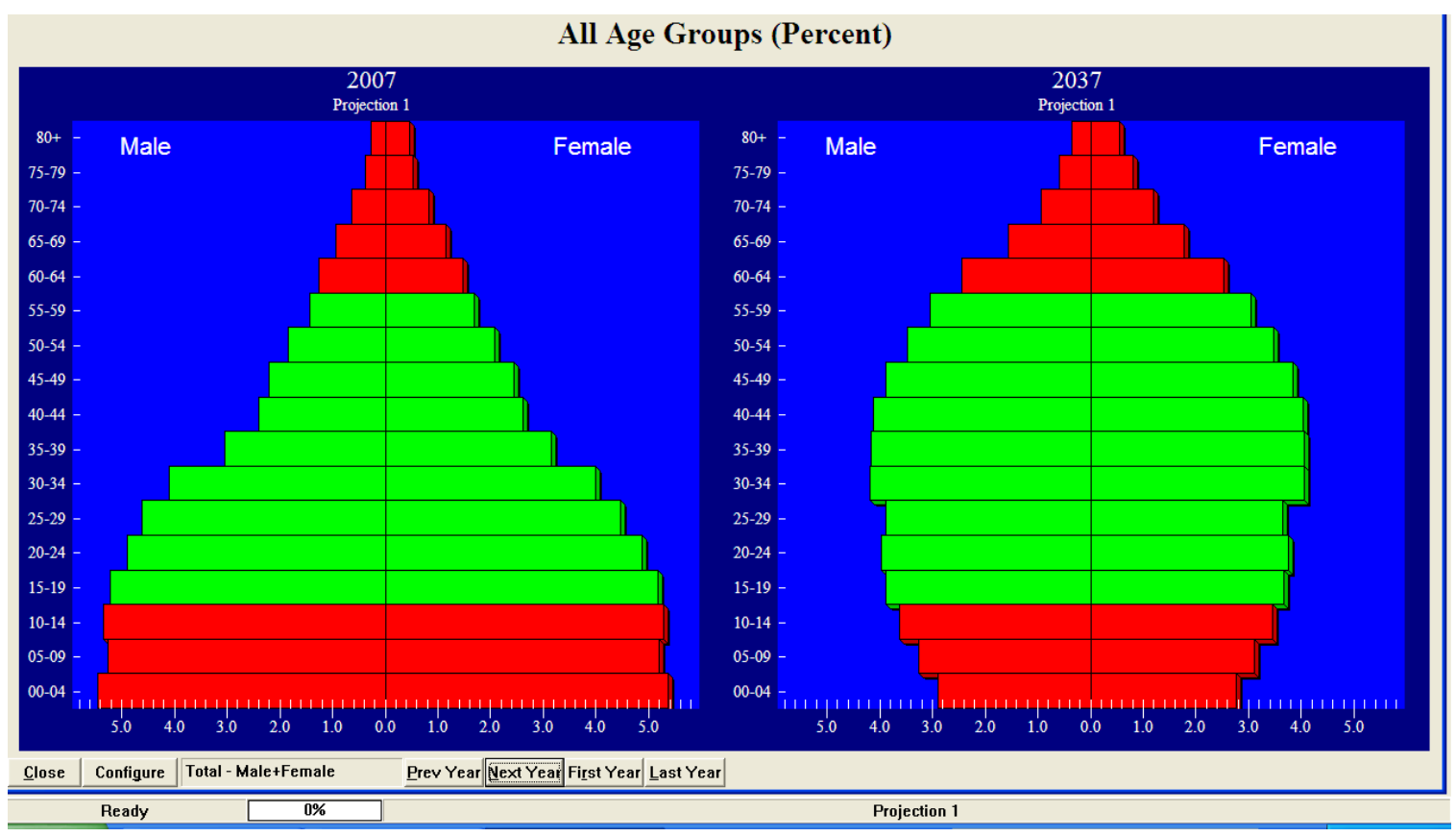

Source: NYDA, 2011

The report further highlights that more than two thirds of the youth live in four provinces: KwaZulu-Natal (22.8\%), Gauteng (21.8\%), Eastern Cape (13.8) and Limpopo (10.9\%). Black South African youths account for $80 \%$ of the population. Whites, Indians and coloureds account for the remaining $20 \%$ of the population. These areas of youth concentration are the worst stricken by youth unemployment and lack of economic opportunities. Furthermore, the $80 \%$ segment of the youth who also happen to be black are the most exposed to poverty, unemployment and lack of economic opportunities.

\subsection{Youth Development Legislative and Policy Framework in South Africa}

Since the inception of democratic rule, the South African government has developed and passed a few pieces of legislation in an attempt to regulate and guide youth development interventions. Amongst others, the government passed the National Youth Commission Act (RSA, 1996b) and recently the National Youth Development Agency Act (RSA, 2008a). The government has also passed compelling policies on youth development. These include the Youth Development Policy Framework for the period 2002-2007, the National Youth Policy for the period 2008-2009. In 2008 the National Youth Development Agency Act (RSA, 2008a) was passed. It was meant to guide the merger of the National Youth Commission and the Umsobomvu Youth Fund. It is aimed at promoting the cohesive, seamless and integrated youth development in South Africa. Thus there is an unequivocal reference to the reliance on the Integrated Youth Development Strategy for South Africa. At the local government level the South African Local Government Association developed the framework for youth 
development and the Department of Provincial and Local Government (DPLG) (now COGTA) initiated to develop the framework for the IYDS for municipalities.

The legislation on youth development serves to regulate the activities and structures of youth development. The provisions in these documents are compulsory. They are the law on youth development in South Africa. On the other hand, policies serve guidelines for youth development, in some instances "policies" are used interchangeably with "strategies" for youth development.

\subsubsection{Youth Development Legislative Framework}

The Constitution (RSAa, 1996) provides for the Bill of Rights endorsed by its citizens by definitions. The citizenship of South Africa includes population members below the age of 35 years. In fact, most of the rights in Chapter 2 of the Constitution are of the direct interest to the Youth. Below is the Bill of Rights as summarized by Adventure Qualifications (undated):

- Equality: You cannot be discriminated against. But affirmative action and fair discrimination are allowed.

- Human Dignity: Your dignity must be respected and protected.

- Life: You have the right to life.

- Freedom and security of the person: You cannot be detained without trial, tortured or punished cruelly. Domestic violence is not allowed.

- Slavery, servitude and forced labour: Slavery and forced labour are not allowed.

- Privacy: You cannot be searched or have your home or possessions searched.

- Freedom of religion, belief and opinion: You can believe and think whatever you want and can follow the religion of your choice.

- Freedom of expression: All people (including the press) can say whatever they want.

- Assembly, demonstration, picket and petition: You can hold a demonstration, picket and present a petition. But you must do this peacefully.

- Freedom of association: You can associate with whomever you want to.

- Political rights: You can support the political party of your choice. If you are a citizen, and at least 18 years old, you can vote.

- Citizenship: Your citizenship cannot be taken away from you.

- Freedom of movement and residence: You can go and live anywhere in South Africa. 
- Freedom of trade, occupation and profession: You can do whatever work you choose.

- Labour relations: You may join trade unions and go on strike.

- Environment: You have the right to a healthy environment.

- Property: Your property can only be taken away from you if the proper rules are followed.

- Housing: The government must make sure people get access to proper housing.

- Health care, food, water and social security: The government must make sure you have access to food and water, health care and social security.

- Children: Children under the age of 18 have special rights, like the right not to be abused.

- Education: You have the right to basic education, including adult basic education, in your own language (if this is possible).

- Language and culture: You can use the language you want to and follow the culture that you choose.

- Cultural, religious and linguistic communities: Communities can enjoy their own culture; practise their own religion; and use their own language.

- Access to information: You have the right to any information which the government has.

- Just administrative action: Actions by the government must be fair.

- Access to courts: You can have a legal problem decided by a court, or a similar structure.

- Arrested, detained and accused persons: This right protects people who have been arrested, imprisoned or accused.

In 1996 Parliament approved the National Youth Commission Act (Act 19 of 1996). Central to its objectives was the provision for the establishment and the management of the matters related to it. Section 3 of the Act outlines the objectives of the commission as follows (RSA, 1996b):

- To co-ordinate and develop an integrated National Youth Policy;

- To develop a National Youth Development Plan;

- To develop principles and guidelines for implementation of the integrated National Youth Policy;

- To implement measures to redress the imbalances of the past;

- To promote a uniform approach to youth matters;

- To promote close liaison with youth development institutions to forge cooperation and foster common policies and practices; 
- To co-ordinate youth development of various institutions of government; and

- To develop recommendations in relation to youth matters.

The National Youth Commission Act (Act No. 19 of 1996) sought to establish a commission that would play an advocacy role on youth development. It did not allow for any budget to be directly allocated for carrying out youth development projects. This was the reason why Umsobomvu Youth Fund was created under the auspices of the National Department of Labour. The NYC Act also provides for the composition of the commission. It is worth noting that the commission was meant to have five full-time commissioners, five part-time commissioners and nine parttime commissioners/provincial representatives nominated by the Premiers. All appointments were to be made by the President of the Republic of South Africa. Commissioners were to serve up to five years in office.

This piece of legislation was later amended by Parliament through Act 19 of 2000. In the main the amendment was to provide for a relationship with provinces (RSA, 2008a). Following the passing of the National Youth Commission Act (Act 19 of 1996), provinces followed by passing their provincial versions. These versions provided for the establishment of the Provincial Youth Commissions and the running of the youth matters. All the provinces, with the exception of the Gauteng, passed the provincial youth commission acts. All these provincial acts were later repealed by order of the Cabinet of the Republic of South Africa following the passing of the National Youth Development Agency Act.

Through the Demutualisation Levy Act of 1998, the government announced the establishment of the Umsobomvu Youth Fund in March 1998. The year 2001 started with a heightened sense of urgency for the youth sector in South Africa. The offices of the Umsobomvu Youth Fund were officially opened by Minister of Finance Trevor Manuel on 30 August 2001. Provisionally registered as a section 21 , not-for-profit company, the Fund's initial mandate was to 'provide monetary grants for skills development or job creation projects of a national character.' On the one hand, there was an accumulated one billion rands waiting to service the needs of disenfranchised young people, while on the other, a youth sector with expectations and a sense of impatience was growing by the day.

Act 54 of 2008 (RSA, 2008a) was passed with an intention to forge a merger between Umsobomvu and the National Youth Commission. The aim was to put in place a youth development institution which would 
promote a cohesive, seamless and integrated youth development programme in the country. The Act repealed the National Youth Commission Act (RSA, 1996b). The Act made it compulsory for the agency to establish satellite offices at local municipal areas. It is clear with regards to the independent budget intended for youth development projects and programmes.

\subsubsection{Policy Framework for Youth Development in South Africa}

In addition to the pieces of legislation mentioned above, the government adopted some broad economic policy frameworks which directly impacted on the welfare of the populace in general, including the youth. These included the Growth, Employment and Redistribution (GEAR) of 1996, the Accelerated and Shared Growth Initiative South Africa (ASGISA) of 2006 and its implementation framework of the Joint Initiative for Priority Skills Acquisition (JIPSA) of 2006, as well as enhancing the improvement of the economic outlook of the country. The New Growth Path was adopted by the Zuma-led government in 2010 as a policy that would turn around the chronic high unemployment, stagnant growth of the economy and the increasing levels of poverty in the communities. The New Growth Path Policy framework, unlike previous frameworks mentioned, provides an integrated framework for macro- and micro-economic measures and social partners into one developmental policy. All the three development elements have a package of interventions that are linked to one another so as to ensure that development focuses on addressing job creation, economic growth, reducing inequalities and poverty and support positive environmental outcomes.

In 2002 the Mbeki-led parliament approved the National Youth Development Policy Framework (NYDPF) 2002-2007, the first of its kind. The NYDPF (2002) emphasized the need for an integrated, holistic, youth development strategy and it served as the navigator for government's youth development programmes and activities. It was aimed at guiding the interventions by general stakeholders to the youth development challenges in South Africa. The framework was premised on the principles of the RDP. This is the reason why at a later stage it was acknowledged that a single-sector approach to youth development, i.e. government, was not enough to address the backlogs on youth development. The NYDPF was preceded by a National Youth Policy 2000. Even though this policy was not formally approved, it became instrumental in influencing government decisions on youth-related issues.

In 2008 Dr Manto Tshabala-Msimang announced that the National Youth Policy: 2009-2014, has been approved by cabinet. This policy ushered in a new era for youth development. It was adopted with more regulatory authority than its predecessor, the NYDPF. The NYP 2007-2014 was finalized in 2008 and would extend from 2009 to 2014. The NYP was based on the need to drive policy on 
youth development and to spell out youth development programmes for the country. The NYP recognises the historical conditions that shaped the conditions in which the youth of South Africa find themselves today. It seeks to create an enabling policy environment under which the youth can thrive and be empowered to meaningfully contribute in the attempts by a developmental state to combat poverty, inequality and unemployment. Accordingly, it defines the disadvantaged and the marginalized youth as the key targets for interventions.

Like its predecessor, the NYP emphasizes the need for an integrated, holistic and sustainable youth development approach. The NYP identifies youth development values and principles, which are based on the democratic principles and the broad developmental vision for South Africa. The NYP's most important contribution to the youth development discourse is the identification of youth development imperatives, identified as education, economic participation, health and wellbeing, social cohesion and civic participation, national youth service and youth work. It is underpinned by various proposals seeking to redress and transform the lives of youths for the better. One way in which the NYP proposes the redress of youth problems is the call for an integrated implementation. There is no clarity on whether the Integrated Youth Development Strategy could play this role, notwithstanding that the interventions it proposes are the main policy interventions.

In the context of local government, it can be argued that in the recent years youth development is a cross-cutting issue, which must be focused on the grassroots level. The most suitable and best place for the youth development service provision is at the level of the local municipalities, since they are the sphere of government closest to the people. Thus the municipalities under consideration have resolved to approve the recommendations by their respective youth development summits to establish youth development units placed in the offices of the Executive Mayors (SALGA, 2007).

In May 2002 there was a national conference organised on local government. It was specifrically devoted to youth development in local government. This conference developed and discussed the Youth Development Guidelines for Local Government (YDG4LG2004).

These guidelines provided that:

- The Department of Provincial and Local Government must ensure that municipal performance plans and IDPs comply with the guidelines (YDG4LG2004);

- The MECs set up oversight structures for this purpose; 
- Councils provide a conducive environment for youth development and exercise oversight to ensure that youth development programmes are carried out;

- The municipalities establish youth units and that the youth units assist in planning setting targets, resourcing youth development mainstream, lobbying and performance management;

- Through youth councils, municipalities must empower youth organizations and civil society to lobby and hold municipalities accountable on youth developments matters;

- The guidelines on the minimum programme content to be included in the DPs i.e. volunteerism, advisory and career guidance services, sports and recreation, skills development-led initiatives, health promotion and environmental action.

In 2007 the South African Local Government Association (SALGA) developed a Youth Development Strategy. This strategy was pitched at a broad strategic level to guide municipalities in dealing with youth development. The strategy appreciates the heterogeneity of youths aged between 14 and 35 years. Accordingly, this strategy arranges the youth into three categories i.e. the 'Teenage group' which is between 14 and 17 years old. The needs of this group are mainly about school, bread and butter issues. More and more they become heads of families. The second category is the 'Youth group', which is aged between 18 and 24 years. The youths in this category are mainly out of school. They include those in higher institutions of learning as well as the youth at work. Their needs are primarily about finishing tertiary training, getting employment and becoming independent from parents/guardians. The last category is identified as the 'Young adults' between the ages of 25 and 35 years. Their needs are primarily about career advancement, starting and maintaining their own family, and playing an important role in society, for example as leaders.

The strategy identifies broad youth development goals. In essence the goals are as follows:

- Youth patriotisms and observance of the Bill of Rights;

- Youth to be the drivers of their own development;

- An integrated and holistic approach to youth development;

- An enabling environment for youth development;

- Skills development, education and training.

This strategy identifies nine Key Focus Areas (KFAs) and outlines activities envisaged In relation to youth development. Finally, the strategy suggests structures to institutionalize youth development in municipalities. This structure in to be located in the office of the mayor, as a stand alone unit. The structure as proposed is to be headed by a Section 57 youth development manager, supported by youth co-ordinators and Youth Development Workers (YDWs), who 
could also be Community Development Workers (CDWs). Figure 7 illustrates the envisaged organisational structure.

Figure 7: Proposed Youth Unit Structure for Municipalities

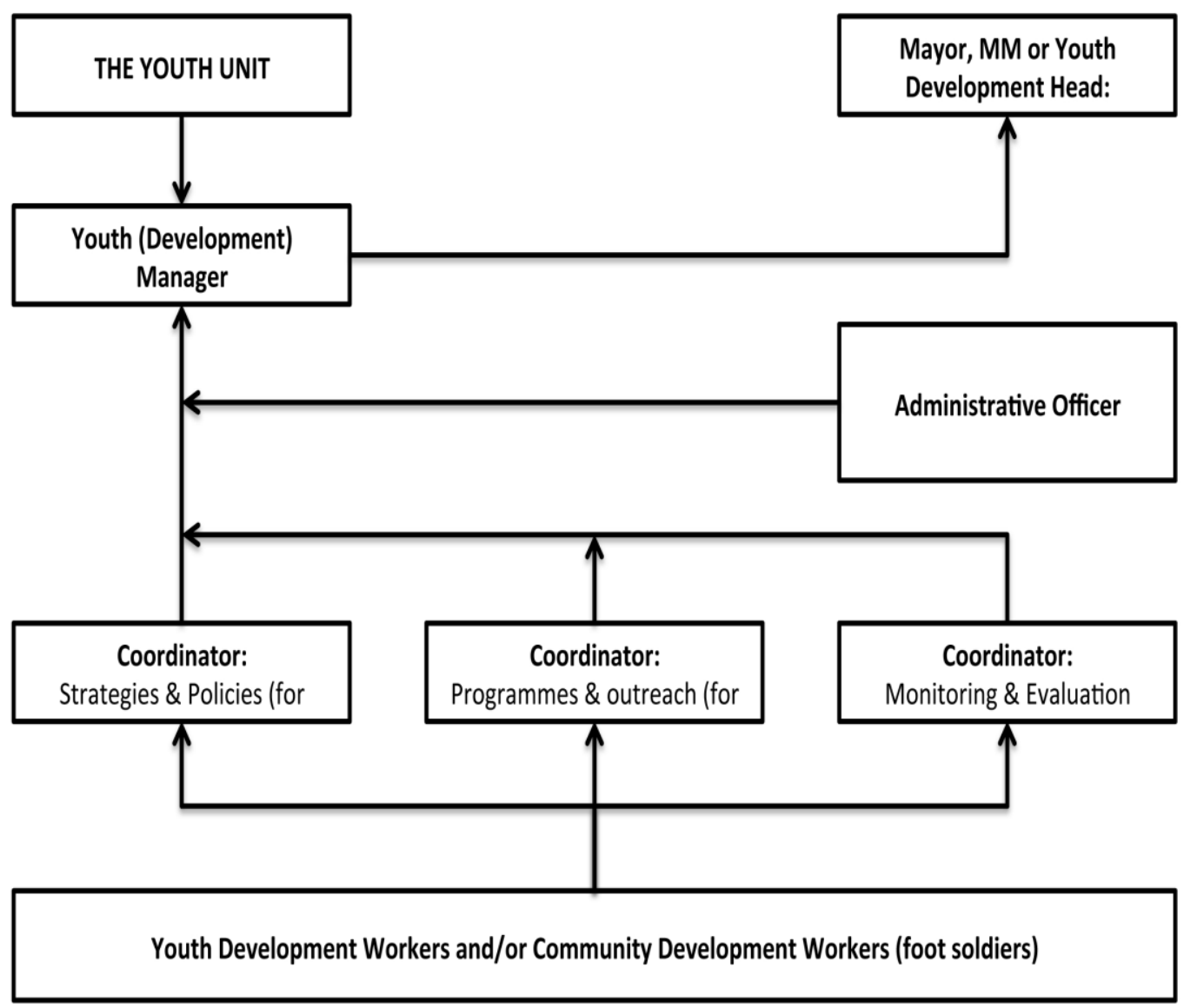

Source: SALGA (2010: 69).

In summation, youth development within South Africa is guided by the following pieces of legislation and policies, at both national and local levels:

- The Constitution of the Republic of South Africa's Bill of Rights provides for the youths' rights to development and protection;

- The NYDA Act defines economic participation as a central objective and, among other things, tasks the NYDA with implementing the NYS;

- The NYS green paper prioritization of the participation of youth in voluntarism as a mechanism to build patriotism and social cohesion;

- The NYS policy framework's definition of youth service as transformative and involving young people in activities that both benefit their communities and help the youths themselves to build their skills and abilities. The NYSPF's holistic approach to youth development is intentionally focused on building 'character and competence'. The approach aims to achieve this by including psychological, economic, social, political and cultural factors into youth service' 
- The New Growth Path (NGP) - the three focus areas that the NGP defines that are directly related to the economic participation thematic area are stepping up education and skill development, enterprise development, and broad-based black economic empowerment. In tourism the NGP identifies the need for measures to expand the infrastructure and services, promote marketing campaigns that are targeted, manage costs, improve training and identify employment and entrepreneurial opportunities for the Youth;

- The African Youth Charter's (AYC) recognition of the right of every young person to participate in all spheres of society as well as the need for holistic and integrated youth development, which includes the provision of multiple access points for education and skills development;

- The United Nations World Programme of Action on Youth (UNWPAY) the UNWPAY recognizes the need for government to promote youth development in general and access to employment in particular through integrated policies. This includes the formulation of integrated youth development policies as well as cross-sectional national youth programmes of action;

- The Millennium Development Goals (MDGs) - the MDGs target the eradication of poverty and hunger (MDG1), the achievement of universal primary education (MDG2), the reduction of child mortality (MDG4) and the improvement of maternal health (MDG5).

\subsection{Conclusions}

Even though the concept of youth development is new, the evidence reviewed in this chapter indicates that the body of knowledge in this area continues to grow exponentially. It is also noteworthy that youth development in South Africa cannot be explained effectively without considering the undesirable history of apartheid and general oppression in South Africa. This becomes even more relevant when the role of the youth against these challenges is narrated. It is also relevant when the approaches by the democratic government, after 1994, in addressing these challenges and inherent development gaps is examined.

While the discussion revealed that there are many definitions of youth, these definitions are not totally different from each other. The authoritative and formal definition is contained in the National Youth Policy 2009-2014. In its conceptualization of the term 'youth', this definition suggests the age bracket of 14 to 35 years. This definition also notes that the legal trading age in South Africa is 18 years. Furthermore, this definition disaggregates this age cohort into three sub-categories. These are 14- to 17-year-olds (teenage group), 18- to 24-yearolds (youth group) and finally 25- to 35-year-olds (young adults). Youth development as a concept, is regarded as both process and outcome, aimed 
at equipping youths with tools and skills in their transition to adulthood as well as empowering them socially, economically and psychologically.

In South Africa the approach to youth development has evolved from a 'problematising' worldview to an opportunity' worldview. This is seen as a fundamental shift from the paradigm in which the youth strata of the population was seen as having been immersed in insurmountable problems and being a problem themselves, to a paradigm where they are seen as a repository of limitless opportunities, a mine of lifelong deposits of platinum, silver and gold, ready to be exploited.

Numerous studies reviewed in this project indicate that there is a great need to plan properly for youth development interventions. It is also suggested that there is a need to improve monitoring and reporting methods and methodology so that all efforts can be accounted for and their impact measured.

Local government has in the past few years made strides that draw it closer to appreciating that youth development is the cornerstone of human development. Any development interventions by government must take into consideration youth development. Both SALGA and CoGTA have made efforts to provide guidelines for youth development in local government. 


\title{
CHAPTER 4: THE CASE OF NKANGALA DISTRICT MUNICIPALITY
}

\begin{abstract}
"The mere formulation of a problem is far more essential than its solution, which may be merely a matter of mathematical or experimental skills. To raise new questions, new possibilities, to regard old problems from a new angle requires creative imagination and marks real advances in science."
\end{abstract}

(Albert Einstein)

\subsection{Introduction}

The previous chapter outlined the research methodology employed in this study. This chapter seeks to describe the environment and the area where the study is conducted, thus assisting with the understanding of the research problem within its reality and context.

The description of the study area in terms of locality, demographic information, socio-economic aspects, education and skills level, health will be covered in this chapter. This chapter will also discuss the state of the youth development structures within the district and all six local municipalities, in relation to the implementation of youth development programmes.

\subsection{Locality}

Nkangala District Municipality is one of the three district municipalities in Mpumalanga. It is located at the Western end of the Mpumalanga Province. It shares borders with Ekurhuleni and Tshwane Metros (Gauteng) to the west, Sekhukhune District (Limpopo Province) to the North, Ehlanzeni District (Mpumalanga) to the east and Gert Sibande District (Mpumalanga) to the south. The District measures approximately 16892 square kilometres with Emakhazeni being the biggest local municipality measuring 4735 square kilometres, and Victor Khanye being the smallest measuring 1597 square kilometres. It is to be noted that both the municipalities have the smallest number of wards and fewer people residing in the same in the district. They both lie at the opposite ends of the district along the N12/N4 corridor. Victor Khanye is at the western end of the district, whilst Emakhazeni is the eastern end of the District (NDM, 2012: 57-59).

Nkangala is composed of six local municipalities. The first is Thembisile Hani, which is bordered by Tshwane Metro and by the Limpopo's Sekhukhuni District Municipality. The second one is Dr Moroka, which shares the borders with Steve Tshwete, Mopani district and Emakhazeni. The third is the Emalahleni, which share the borders with Victor Khanye, Steve Tshwete, Thembisile Hani and Gert Sibande District. The fourth is Victor Khanye, which is at the western edge of Mpumalanga Province, sharing borders with Ekurhuleni Metro, Tshwane Metro, Emalahleni Local Municipality and Gert Sibande District. The fifth Municipality is 
Steve Tshwete, bordered by Limpopo's Sekhukhune District, Emalahleni, Thembisile Hani and Emakhazeni. The sixth and the last local municipality under Nkangala is Emakhazeni, which is bordered by Steve Tshwete, Gert Sibande District and Thaba Chueu (NDM; 2008: 22-24).

The following map illustrates the spatial location of Nkangala District Municipality, Local Municipality within the Nkangala District and the surrounding provinces and Districts.

Figure 8: Nkangala District Locality Map

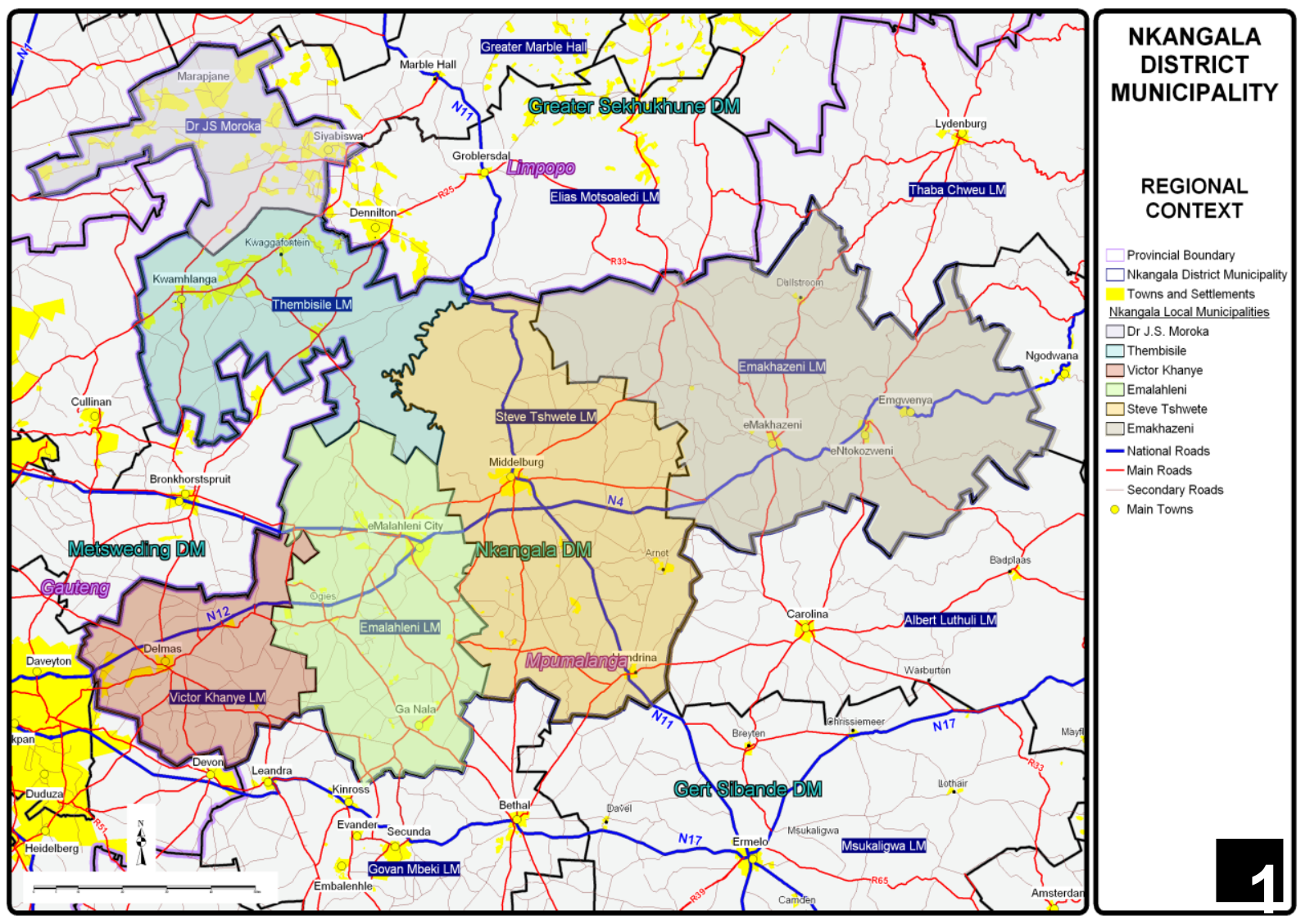

Source: NDM IDP 2009/2010

\subsection{Demographic Information}

The community survey for the year 2007 estimated that there is a population of just over 1.22 million people living in Nkangala District Municipality. The mostl densely populated local municipality was Emalahleni and the least populated was Emakhazeni Local Municipality, with 435223 and 32838 people respectively. In both instances the yearon-year population increases and declines indicate strong migration patterns, where people move in search of economic opportunities, among other reasons. This is due to the fact that Emalahleni Municipality as contrasted to Emakhazeni Municipality is highly industrialized. 
Generally, the population figures of the district show an average annual population increase of $2 \%$. Figure 9 illustrates the population pyramid by age, as at 2007 (NDM, 2009: 41).

Figure 9: Population of the Nkangala District by Age and Gender

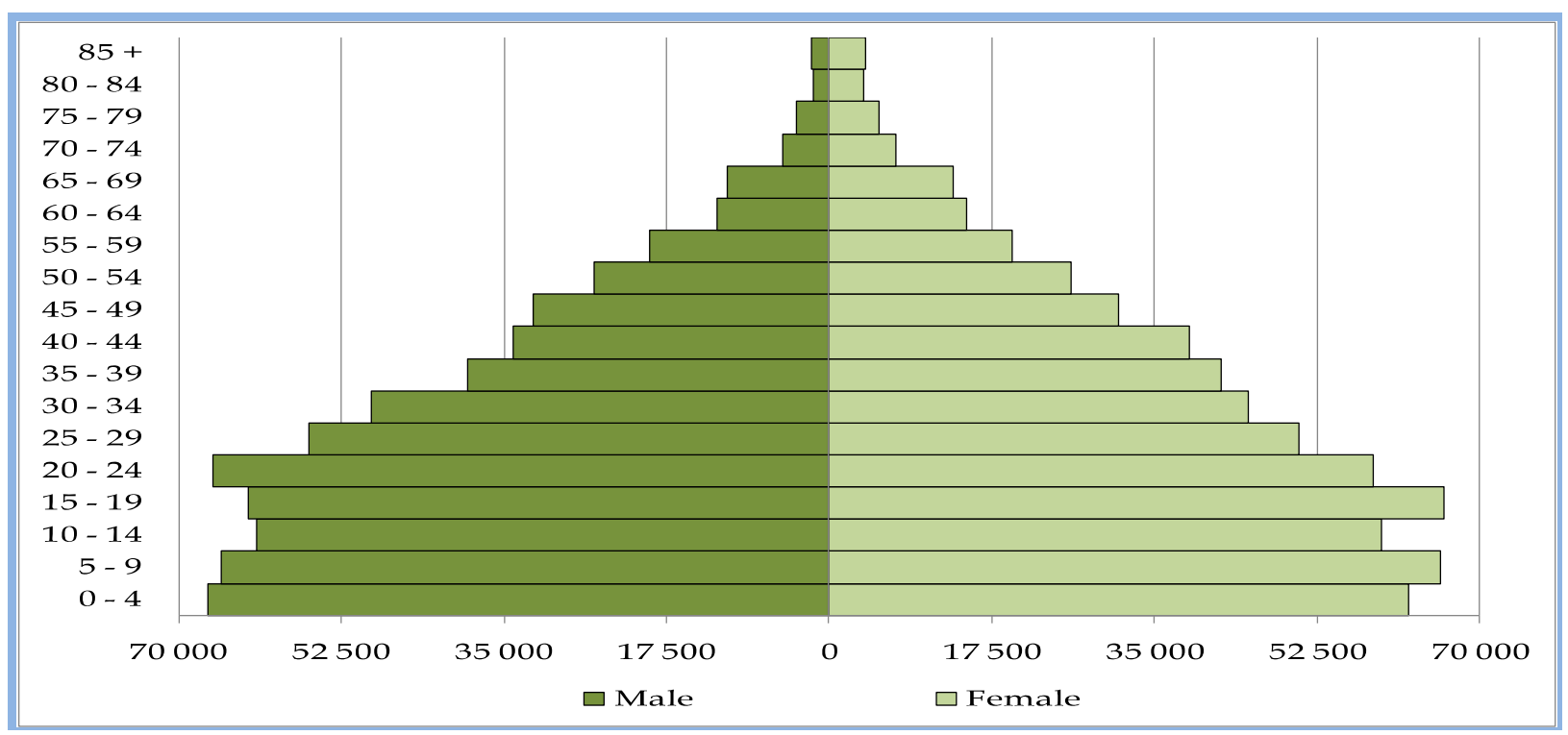

Source: NDM Annual Report 2009/ 2010

The population of the district is composed of $81 \%$ Africans, $15 \%$ whites, $3 \%$ coloureds and $1 \%$ Asians. It is composed of over $70 \%$ young people (those aged 35 years and younger). $42 \%$ are youths, i.e. older than 14 years but younger than 36 years. Even though these figures are in line with the national estimates, there are variations from one local municipal area to another. Dr JS Moroka and Thembisile Hani recorded the highest numbers of young people (0-24 years) with a population share of $60.5 \%$ and $60.3 \%$ respectively, whilst Emalahleni Municipality recorded highest percentage of adults (25-64 years) at $49.4 \%$. This led to the adult population estimate of the district exceeding the provincial estimate by $45.4 \%$ against $43.6 \%$, (NDM, 2008: 55-56).

\subsection{Economic Activities}

The major economic activities in the district are community services, mining, manufacturing and electricity. Other minor activities include, inter alia agriculture, trade, construction, finance and transport (NDM, 2008:62).

Up to the year 2002 the district showed increases in the finance, transport, trade and manufacturing sectors. It must be recorded that electricity and construction would have increased over the last 10 years due to the construction of Kusile Power Station between Delmas and Ogies. Dr J.S. Moroka and Thembisile Hani municipalities' economic activities are dominated by 
community services and Trade. They also individually benefit from electricity. Mining, manufacturing and electricity are the strongest in Delmas, Emalahleni and Steve Tshwete. Agriculture is the strongest in Victor Khanye and Emakhazeni Local municipalities.

When using the "tress Index" relative levels to measure of diversification and concentration, Victor Khanye Local Municipality was the only Municipality that demonstrated an increasing level of economic concentration. It must be noted that for all municipalities under review the index indicated acceptable levels of measurements (NDM, 2008: 63-81).

Table 3: Tress Index of All Municipalities

\begin{tabular}{|l|c|c|c|c|}
\hline Area & $\mathbf{1 9 9 6}$ & $\mathbf{2 0 0 2}$ & Adjustment & Trend \\
\hline Dr JS Moroka & 69.5 & 66.0 & 3.5 & $\downarrow$ \\
\hline Thembisle & 71.6 & 68.6 & 3.0 & $\downarrow$ \\
\hline Delmas & 49.8 & 50.7 & 0.9 & $\uparrow$ \\
\hline Middelburg & 61.7 & 61.5 & 0.2 & $\uparrow$ \\
\hline Emalahleni & 61.5 & 60.0 & 1.5 & $\downarrow$ \\
\hline Emakhazeni & 49.1 & 47.7 & 1.5 & $\downarrow$ \\
\hline
\end{tabular}

Source: Nkangala Spatial Development Framework 2008

The economically active population in the district accounts for $34.8 \%$. Using the narrow definition of unemployment, the district recorded an unemployment rate $25.1 \%$ in 2008 , which is higher than the Mpumalanga provincial unemployment rate of $21.8 \%$. It is estimated that over $42 \%$ of the unemployed are young people between the ages of 15 and 35 years (NDM, 2010). Most of the people are employed in the community and social services, wholesale and retail, mining and domestic work sectors or industries. About $26.5 \%$ of the workers, worked in the elementary occupations, $19 \%$ worked in the craft and related trade work. In the Victor Khanye and Emakhazeni Local Municipalities there are more skilled agricultural workers (9\%) (NDM, 2009: 45-46).

\subsection{Education and Skills Development}

The level of education in the District is generally very low. Developmental theories hold that education determines and influences the welfare of a society. In the District $25 \%$ of the adult population have not attended any formal schooling. $25 \%$ of the school-going age (2-24years) do not attend any form of education institutions. Only $22.5 \%$ adults have matric certificates, whilst only $6.7 \%$ have post-matric qualifications. 
It is important to note that in 2008 the population registered improvements in education levels. The population with no formal schooling decreased from $20.1 \%$ in 2001 to $13.1 \%$ in 2008. People with matric and post-matric qualifications increased to $4 \%$ and $1 \%$ respectively in 2008 . Functional literacy increased by $11 \%$ to $72.8 \%$ in 2008 . Victor Khanye remains the hardest hit by illiteracy in the district. The education levels of the society, specifically in the District, have a direct effect on the employability of the youth and the working force.

\subsection{Health and Wellbeing}

The society and especially the economically active can be affected by numerous socio-economic issues. Young people in particular are largely affected by the HIV/AIDS epidemic. HIV/AIDS remains a serious threat to the development of youth of South Africa and the district in particular. The deaths from the HIV/AIDS epidemic are a cause for concern as the number of childheaded households continues to soar, affecting the family structures and cohesion. It was estimated that there will be approximately 2 million orphans in 2010 as the result of HIV/AIDS (NDM, 2010).

According to the Department of Health (2009:4), the UNAIDS indicated that Mpumalanga is rated number two at $21.8 \%$ after KwaZulu-Natal which is at $25 \%$ in terms of the provincial HIV prevalence. According to this report, the statistics of the UNAIDS report are consistent with findings on HIV prevalence amongst antenatal women. This report also shows that even though the District is not in the top ten districts in country for high prevalence, its scoring $(32.5 \%)$ is above the national average of $29.4 \%$. Nkangala district remains the lowest amongst the province's districts and it is lower than the provincial average of $34.7 \%(\mathrm{DoH}$, 2009:48-49). The following figure shows the HIV prevalence trends by District in Mpumalanga. It can be seen that even though Nkangala is the lowest, it continued to rise steadily in the three years under review. 
Figure 10: Mpumalanga HIV/ AIDS Prevalence Results by District

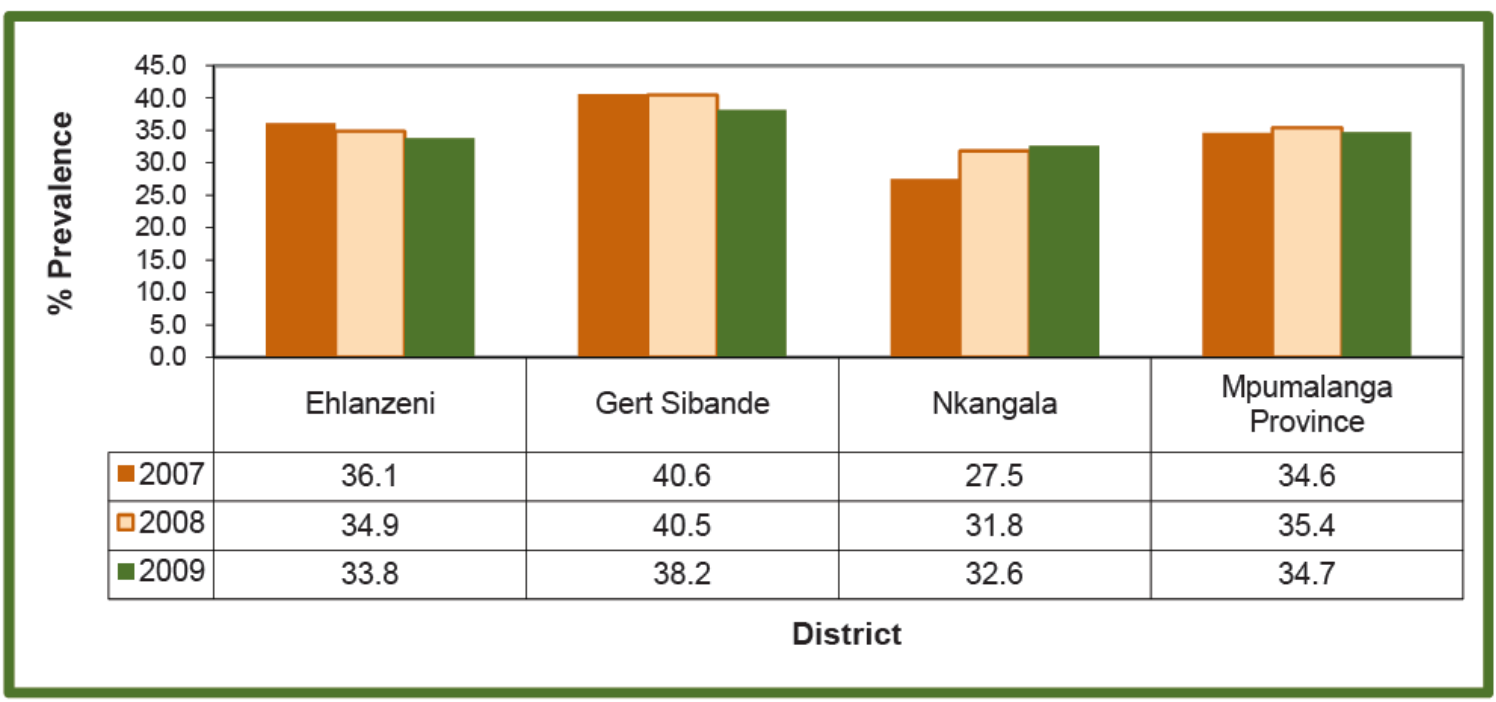

Source: Republic of South Africa, 2010: 48

Each and every municipality within the district has at least both a health clinic and a hospital. This is with exception to Dr J.S Moroka and Thembisile Hani, which only have Health clinics. Steve Tshwete and Emalahleni Municipalities are even endowed with private hospitals.

\subsection{Youth and Crime}

According to the Institute for Futures Research, South Africa remains one of the countries where crime is still rampant. The recent crime statistics indicate a decline in areas such as violent crimes, sexual offences, violent and common robbery, murder and attempted murder. It is noted that despite this encouraging decline, public violence, which incudes violent protests, is on the rise. During 2011/2012 year, police attended to 1214 incidences of public violence, a 25\% increase on the previous year's incidences (Haldenwang, 2012) (Palmary, 2003).

In response to the millennium development goals, South Africa responded through Vision 2014 by, amongst other things, setting itself a goal to significantly reduce serious and priority crimes by introducing programmes that address the social roots of the problems.

In South Africa crime is largely exacerbated by societal challenges such as weak family structures, poverty, the adverse and varied impacts of the HIV/AIDS pandemic, and poor social cohesion. It is recognized that these are not the sole causal reasons for crime.

The graph in Figure 11 illustrates the extent to which youths are affected by crime. 
Figure 11: Crime Statistics by Crime Categories and Age Group

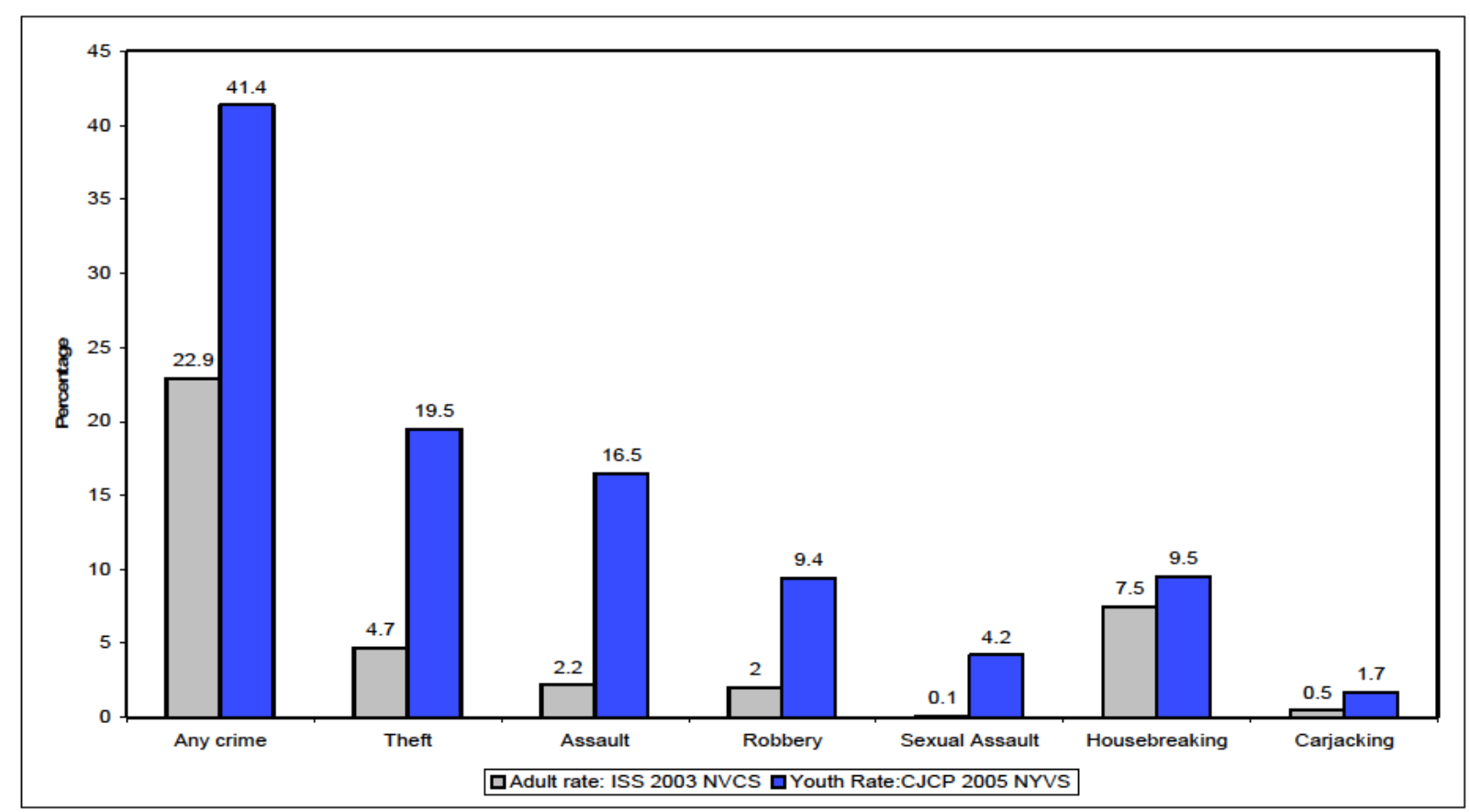

Source: Pelser, 2008: 2

Even though the National Crime Statistics (2010) do not indicate clearly the extent to which the youth are affected by crime either as victims or perpetrators, the age profile of those in prisons who have been sentenced or are awaiting trials suggests that the majority of the offenders are below the age of 35 years. Due to the fact that more than $70 \%$ of the population in South Africa are youths, arguably, the youth are the population group mostly affected by crimes against society. Victimisation also occurs at homes and schools. In fact young people between the ages of 12 and 22 years are affected at twice the adult rate in South Africa. These crimes include property theft, violent and sexual crimes, assault, drug and substance abuse (Pelser, 2008)

The people and youths of Nkangala District Municipality are not immune from the challenges depicted at the national level. More specifically, there are statistics collected from the police stations within the district. These statistics confirm that there in consistency in the levels of crime at the national level and the district. Table 4 illustrates the statistics of crime in terms of municipal areas within the district (NDM, 2012). 
Table 4: Crime Statistics by Local Municipality

\begin{tabular}{|c|c|c|c|c|c|c|c|}
\hline \multirow{2}{*}{$\begin{array}{l}\text { Local } \\
\text { Municipality }\end{array}$} & \multirow[t]{2}{*}{ Police Station } & \multicolumn{6}{|c|}{ TYPE OF CRIME(2009/10) } \\
\hline & & Murder & $\begin{array}{l}\text { Total } \\
\text { sexual } \\
\text { crimes }\end{array}$ & $\begin{array}{c}\text { Burglary at } \\
\text { residential } \\
\text { premises }\end{array}$ & $\begin{array}{l}\text { Robbery with } \\
\text { aggravating } \\
\text { circumstances }\end{array}$ & $\begin{array}{l}\text { Drug- } \\
\text { related } \\
\text { crimes }\end{array}$ & $\begin{array}{l}\text { Driving } \\
\text { under the } \\
\text { influence of } \\
\text { alcohol or } \\
\text { drugs }\end{array}$ \\
\hline \multirow[t]{4}{*}{ Emakhazeni } & Belfast & 2 & 20 & 112 & 33 & 12 & 12 \\
\hline & Dullstroom & 2 & 5 & 78 & 5 & 4 & 3 \\
\hline & $\begin{array}{l}\text { Watervaal } \\
\text { Boven }\end{array}$ & 1 & 10 & 89 & 9 & 9 & 5 \\
\hline & Sub-Total & 5 & 35 & 469 & 47 & 25 & 20 \\
\hline \multirow{5}{*}{$\begin{array}{l}\text { Steve } \\
\text { Tshwete }\end{array}$} & Middelburg & 22 & 108 & 799 & 264 & 71 & 202 \\
\hline & Blinkpan & 11 & 16 & 43 & 39 & 18 & 15 \\
\hline & Hendrina & 8 & 26 & 134 & 40 & 20 & 45 \\
\hline & Mhluzi & 21 & 102 & 69 & 69 & 47 & 101 \\
\hline & Sub-Total & 62 & 252 & 1045 & 412 & 156 & 363 \\
\hline \multirow{5}{*}{ Emalahleni } & Kriel & 5 & 36 & 296 & 48 & 19 & 14 \\
\hline & Ogies & 10 & 40 & 202 & 137 & 30 & 27 \\
\hline & Vosman & 45 & 203 & 678 & 295 & 184 & 52 \\
\hline & Witbank & 33 & 113 & 1805 & 609 & 125 & 86 \\
\hline & Sub-Total & 93 & 392 & 2981 & 1089 & 358 & 179 \\
\hline \multirow{2}{*}{$\begin{array}{l}\text { Victor } \\
\text { Khanye }\end{array}$} & Delmas & 9 & 74 & 340 & 230 & 43 & 25 \\
\hline & Sub-Total & 9 & 74 & 340 & 230 & 43 & 25 \\
\hline \multirow{5}{*}{$\begin{array}{l}\text { Thembisile } \\
\text { Hani }\end{array}$} & Kwaggafontein & 14 & 87 & 186 & 75 & 38 & 66 \\
\hline & KwaMhlanga & 23 & 172 & 575 & 183 & 52 & 347 \\
\hline & Tweefontein & 4 & 68 & 203 & 66 & 89 & 17 \\
\hline & Verena & 2 & 24 & 57 & 49 & 15 & 4 \\
\hline & Sub-Total & 43 & 351 & 1021 & 373 & 194 & 434 \\
\hline \multirow{4}{*}{$\begin{array}{l}\text { Dr.JS } \\
\text { Moroka }\end{array}$} & Mmametlake & 11 & 69 & 165 & 39 & 38 & 15 \\
\hline & Siyabuswa & 29 & 136 & 274 & 155 & 47 & 10 \\
\hline & Vaalbank & 7 & 70 & 118 & 82 & 26 & 10 \\
\hline & Sub-Total & 47 & 344 & 557 & 276 & 111 & 35 \\
\hline
\end{tabular}

Source: Nkangala Integrated Development Plan 2012/13

\subsection{Youth Development Structures in the Municipalities within the Nkangala District Municipality}

Following the youth development summits held in 2004 and 2006 in Kopanong and Klopperheimer, the Council of the District established a youth development unit in keeping with the guidelines of SALGA's envisaged structured arrangement. All municipalities followed suit and held youth development summits and subsequently established their Youth Units (NDM, 2009:61). 
Most of the municipalities would employ only one official in the youth development unit. At most, the municipality would employ two officials, the youth development manager and the youth development co-ordinator. CDWs would be seconded to work in the units as youth workers who refer cases to the officials in the youth development units.

During the youth development summits held by the District and Local Municipalities, the delegates would also elect the leadership for the District and Local Youth Councils, under the stewardship of the South African Youth Council. These structures will have the responsibility to guide the municipality and the youth development units in addressing youth development challenges. In all six Municipalities and the District, Youth Councils were in place at the time of the study (NDM, 2010).

The District appointed experts to help with the formulation of the IYDs for the District. This was to be a strategy which would amalgamate the resolutions taken at the two Youth Development Summits in 2004 and 2006. The plan identifies strategic areas, namely governance and youth capacity building; procurement and financial assistance; communication; skills development and education; Infrastructure; health and welfare; safety and security; social cohesion; economic development; arts, sports, recreation and environment; and rural development.

The District's draft IYDS also identifies short-term interventions. These are mainly projects to be implemented within a shorter time span, along the identified strategic areas (NDM, 2010). The intention was to ensure that all local municipalities follow suit and develop a local IYDS. However, only Thembisile Hani and Emalahleni Local Municipalities developed the their local IYDS. Other municipalities opted to simply highlight the youth development issues in their Integrated Development Plans.

According to the draft IYDS (NDM, 2010), the successful implementation, monitoring and evaluation of the youth development programmes and projects was to depend on:

- The sound structures for youth development in the District;

- Involvement of and buy-in by government departments and the private sector;

- Monthly meeting with the youth structures;

- Physical site visits of projects by respective youth units; 
- Projects tracking systems;

- Evaluation of the effectiveness and efficiency of the programmes and projects.

According to the IDP $2012 / 2013$, all six municipalities have put a performance management framework and system in place. This is for the general performance management of both the organisational and individual work conducted by the municipalities.

There is, however, lack of evidence that the performance agreements and plans do actually integrate youth development targets. Thus the task of monitoring and evaluating the progress on youth development is misguided. At this stage the municipalities within the District report on youth development on the basis of ad hoc and occasional projects and programmes that might have been unexpectedly funded by private donors.

\subsection{Conclusion}

This chapter was aimed at introducing the reader to Nkangala District Municipality with a socio-economic profile of the district. Aspects such as education and health are also discussed in this chapter. The presentation of the information in this chapter is specifically in relation to the youth population of the Nkangala District Municipality.

The next chapter will draw from this chapter and the desk-top information relevant to the study, and further expand on the interviews with the participants. The focus group discussions will further help explore the deductions from the literature study and claims from the individual interviews. 


\title{
CHAPTER 5: RESEARCH METHODOLOGY
}

\author{
"A journey of a thousand miles begins with a single step [and a road map]." \\ (Adapted from Chinese philosopher, Lao Tzu, 604 BC - 531 BC)
}

\subsection{Introduction}

The researcher is required, just as in any other study, to make use of an overall guiding philosophy, to define the procedures, employ tools to collect data, measure variables and analyse information. Dawson (2007:15) draws a clear distinction between research methodology and research methods. She sees the former as the philosophy guiding the researcher and the latter as encompassing procedures and tools for gathering data. This understanding has guided and underpinned the study.

This view is also asserted by Welman, Kruger and Mitchell (2008:1). They see research methodology as the overall logic behind the research methods and techniques. Research methods are referred to as the application of objective methods and procedures. Objectivity in this instance refers to non-reliance on the personal views, opinions and feelings of the researcher. However, those of the participants are considered important.

As indicated earlier, the primary aim of the study is to evaluate the current performance management in relation to youth development in the municipalities. This is done in order to recommend and to establish a framework for youth development, appropriate key development areas for the youth in local government and a framework for the application of existing performance management system on youth development.

Accordingly, the purpose of this chapter is to outline the research methodology preferred in approaching the study. The chapter will discuss the research methodology in which the philosophy guiding the methods, the research methods, which will cover research population, data collection, data analysis, as well as issues of validity and reliability of the data are discussed.

\subsection{Research Design and Methodology}

There are mainly two categories of research philosophies, the quantitative research approach and the qualitative research approach. The former is also referred to as the positivist approach. It is preferable for more scientific studies. The latter is also known as the anti-positivist approach and is preferable when the study considers, for example, human behaviour, perceptions and opinions, (Leedy, 2005) and (Welman et al., 2008). 
Table 5 illustrates the differences between the qualitative research approach and the quantitative research approach.

Table 5: Qualitative Approach versus Quantitative Approach

\begin{tabular}{|l|l|}
\hline Quantitative Approach & Qualitative Approach \\
\hline Deals with objective data & Deals with subjective data \\
\hline $\begin{array}{l}\text { Uses complex structured analysis } \\
\text { methods }\end{array}$ & $\begin{array}{l}\text { Uses flexible and exploratory analysis } \\
\text { methods }\end{array}$ \\
\hline Study more abstract of reality & Study more day-to-day events \\
\hline Biased to outsiders' views & Biased to insiders' views \\
\hline Prefers stable environment & Prefers dynamic environment \\
\hline Particularistic in data collection & Holistic in data collection \\
\hline Depends more on the reliability of data & Depends more on the validity of data \\
\hline Involves larger numbers (population) & Involves small samples for in-depth studies \\
\hline
\end{tabular}

Source: Adapted from Welman et al (2008:8-9)

According to Coldwell and Herbst (2004: 13-16), the quantitative approach is about objective information and the usage of mathematical techniques to analyse it. Welman et al. (2008: 188) assert that this approach uses numbers to describe, infer and resolve problems. For example, it can be used to calculate the number of young people living with HIV and AIDS. Cresswell (2009: 4) further asserts that the findings can be generalised and replicated.

On the other hand, qualitative research is about the generation of data without using mathematical techniques. The researcher attempts to investigate day-to-day events. Coldwell and Herbst (2004: 13-16) argue that qualitative research refers to instances where the study information cannot be measured numerically. In these instances mathematical techniques cannot be used to analyse information. This is further supported by Welman, Kruger and Mitchell (2008: 188), who describe quantitative research as a descriptive form of research which can be used in describing groups, communities and organisations. They assert that this research philosophy has numerous underpinnings, including the phenomenological approach, action research, case studies, historical studies and others. This research is normally used to examine feelings and perceptions (Cresswell, 2009:4).

Cresswell (2009: 3-4) argues that in fact the quantitative and qualitative approaches should not be viewed as dichotomous, but rather as two points lying at the ends of a continuum. His argument is that studies are never purely quantitative or qualitative, but they are rather more of one than the other. He then introduces the third approach, that he terms the mixed methods approach. This approach has more strength than the two, as in the principle of synergy, referred to as $1+1$ is equals to 3 . This is because of the 
combination of qualitative and quantitative methodologies to guide the study, and the mixing of tools for data collection and analysis.

Leedy (2005: 134-135) describes the instances at which researchers should choose a qualitative approach. He argues that a qualitative approach is applicable when a study serves as a description, interpretation, verification and evaluation. In this study the researcher's purpose is to describe the nature of both youth development and performance management within local government. The researcher will also evaluate the extent to which the frameworks youth development and performance management have been successfully implemented in Nkangala District Municipality.

The researcher has chosen to make use of the qualitative approach. The study will further explore the attitudes, behaviour and experiences of the participants with regards to performance management and youth development, which is remains in line with a qualitative research approach.

For the purposes of this study, the researcher has chosen the case study research method. In this approach a limited number of units of analysis are studied in detail. This normally refers to one unit of study such as the individual, groups or institutions. In the end the findings are applied to other similar units (Welman et al., 2008: 193) This explanation of a case study approach is also supported by Leedy (2005: 135-136).

NDM was considered using the case study approach. This allowed the researcher to generate inferences to other municipalities and generalise to the 52 District Municipalities, because local government systems and structures are standardised in South Africa. For the purposes of this study, data were collected through the review of documentation from the NDM, semi-structured interviews and the focus group discussions, and was used to inductively inform the findings. The researcher reviewed the NDM IDP 2009/10, the Annual Report 2009/10, the NDM Performance Management Framework, Integrated Youth Development Strategy for NDM and the Report of the Youth Summit held in 2004.

The intention of the study is to find a solution to the problem as stated earlier. This will be achieved by developing a model for an individual performance management system for the youth development managers. Although the preliminary literature survey, as explained by Welman et al. (2008: 25), indicates that there are substantial theories, especially on performance management, the purpose of this research is not to test the existing theories on performance management, but to provide a solution to the problem under consideration. The selected design, according to Welman et al. (2008: 205-206), is versatile in that it can be changed to adapt to information and results. It also places the participants at the centre of the research. 


\subsection{Research Methods}

Welman et al. (2008:52) describe research methods as procedural plans according to which researchers select participants, collect and analyse information. This assertion is augmented by Dawson (2007: 15), who says that research methods are tools used to gather data such as interviews and questionnaires, and inferring techniques.

As guided by Leedy (2005:135), the researcher made use of mainly three techniques. They are a literature review, semi-structured interviews and focus group discussions. The discussion below will first address these aspects under the theme data collection and then under data analysis.

\subsubsection{Data Collection}

This section identifies existing and primary data collection methods, the participants and the sampling method, the interviews as well as the focus groups.

Creswell (2008: 25-27) argues that literature review should be used irrespective of the research approach chosen for the study. However, the degree and the details, as well how the literature review is used, will vary from one approach to another, and the basis of the research techniques chosen. For the purpose of a qualitative approach, he argues that literature review could be used in three different ways. It could be used by placing it in the introduction section to frame a research problem, or by placing it as a separate chapter as a literature review or by placing it right at the end and using it as the basis for comparing and contrasting the findings.

The researcher employed the usage of research for two purposes. In the introductory chapter, he made use of the literature review to frame the research problem, and as a separate chapter as a literature review.

During this activity the researcher focused his study on three main sub-techniques, i.e. a review of the theories and models. Theories and models on PM and youth development were considered both locally and internationally. The researcher also examined existing studies on both performance management and youth development, reviewed legislation and legislative and policy frameworks and a review of NDM documentation. The framework set by the legislation and other government policies will include Acts, Regulations, Policies and Youth Development Strategies. The researcher also looked at the existing performance management system in the municipality under consideration.

On youth development, though literature was found to be limited, especially in South Africa and at local government level in particular, theories and models were considered in as far as they do exist. There are studies on a range of subjects underpinning youth development; these were considered and summarised. The researcher considered all available pieces of legislation and policies on youth 
development in South Africa. The researcher considered the Skills Development Act, which authorised the establishment of the former UYF, the National Youth Commission Act and its amendment which established the former NYC. The National Youth Development Act, which repeals all the previous acts, directs the merger of the former UYF and NYC, and ushers in the National Development Agency. And finally the study considered information from existing organisational documentation, i.e. NDM's IDP 2009/2010, the Annual Report for the year 2009/2010, Performance Management Framework, Youth Development Strategy and Youth Summit Report. Chapter 3 discusses the details on the subject of youth development in South Africa.

On performance management, literature was found in abundance, hence the literature review was more focused to be local government specific. Theories and models of performance management were explored and explained according to their relevance to the study. Most of the models used in this section were already adopted by South African local government. There are studies focusing on both organisational and individual performance management in municipalities and these were used to inform the analysis of the findings. Legislation and policies on performance management, especially in local government, such as the Constitution of the RSA, MFMA, MSA, Performance Management and Planning Regulations, were reviewed. Finally, the researcher considered information from existing documentation. These are the NDM's IDP 2009/2010, Annual Report for the year 2009/2010 and Performance Management Framework. Chapter 2 discusses the details on the subject of performance management in local government.

\section{Semi-structured Interviews}

The study made use of face-to-face, one-on-one interviews. In some instances where there was no clarity on the response of the participant, the researcher made follow-up telephone calls. For the one-on-one interviews, only the youth development manager at NDM, municipal manager at NDM, executive mayor at NDM, performance management official at NDM, chairperson of SAYC in the district, the councillor responsible for youth development in NDM, District chairperson and secretary of SAYC in NDM, were interviewed.

As advanced by Leedy (2005: 146), the interviews can generate a great deal of useful information, i.e. facts, beliefs and perspectives on facts, feelings, motives, present and past behaviours and reasons for actions. It must be noted though, that because the participants will rely on their personal memory, responses could be inaccurate. Furthermore, it should be noted that because these interviews were open-ended, they could yield information which is not comparable. 
Table 6: Alignment of Research Questions with Interview Questions

\begin{tabular}{|c|c|}
\hline RESEARCH QUESTIONS & INTERVIEW QUESTIONS \\
\hline $\begin{array}{l}\text { A. What defines youth development } \\
\text { and youth development planning } \\
\text { in local government? }\end{array}$ & $\begin{array}{l}\text { 1. How does your municipality } \\
\text { define youth? } \\
\text { 2. Does your municipality have an } \\
\text { approach and or framework to } \\
\text { Youth Development? } \\
\text { 3. What are the main areas of focus } \\
\text { for youth development in your } \\
\text { municipality? } \\
\text { 4. Does your municipality have a } \\
\text { comprehensive } \\
\text { Development Plan or Strategy? } \\
\text { 5. Are any of your planning } \\
\text { processes for youth development } \\
\text { allowing for youth participation? } \\
\text { 6. Does you IDP or LED or any } \\
\text { broader municipal development } \\
\text { plans, address } \\
\text { development issues? }\end{array}$ \\
\hline $\begin{array}{l}\text { B. Is the municipality making use of } \\
\text { any performance management } \\
\text { system for youth development? }\end{array}$ & $\begin{array}{l}\text { 7. Does your municipality have a } \\
\text { performance framework and } \\
\text { systems? } \\
\text { 8. Arising out of the above, does } \\
\text { your municipality have a } \\
\text { performance management plan } \\
\text { in place? } \\
\text { 9. To what extent, are the youth } \\
\text { development issues integrated } \\
\text { into the performance } \\
\text { management plans? } \\
\text { 10. Do individual performance } \\
\text { management contracts and plans of } \\
\text { the MM, and Youth Development } \\
\text { Managers, include } \\
\text { development targets youth }\end{array}$ \\
\hline $\begin{array}{l}\text { C. Does the municipality have clearly } \\
\text { defined performance measures for }\end{array}$ & $\begin{array}{l}\text { 11. Are there relevant youth } \\
\text { development KPAs identified? }\end{array}$ \\
\hline
\end{tabular}




\begin{tabular}{|c|c|}
\hline RESEARCH QUESTIONS & INTERVIEW QUESTIONS \\
\hline Youth development? & $\begin{array}{c}\text { 12. Are clearly defined KPIs and } \\
\text { targets defined? }\end{array}$ \\
$\begin{array}{c}\text { 13. Are there clearly defined } \\
\text { performance targets for youth } \\
\text { development in place? }\end{array}$ \\
$\begin{array}{l}\text { 14. How are these performance } \\
\text { measures derived? } \\
\text { 15. Are these measures integrated } \\
\text { into the PM plans (i.e. Individual } \\
\text { and organisational) for the NDM? }\end{array}$
\end{tabular}

Source: Adapted from Leedy (2005:148)

Broad research questions for the interview were developed in relation to the research objectives. This guided the formulation of interview questions, which were administered to the participants in the form of long and detailed semi-structured interviews. The open-ended guiding questions were used to encourage and spark participation by the population. This approach is affirmed by Leedy (2005: 146), who observes that these interviews should last as long as 1-2 hours.

\section{Focus Group Discussions}

In the study the shortfalls described in the section on semi-structured interviews were moderated by the focus group discussions, whereby the researcher appointed a moderator to introduce discussion points and maintain focus and order during the discussions. Table 3 depicts how the research questions were used to develop clusters of interview questions by stating all interview questions in the same cluster against the research questions.

Focused interviews were held with groups involved in youth development in the NDM (Creswell, 2008: 181). There were three focus group discussions. The first was a group of seven, consisting of SAYC leadership in the NDM and municipalities within it, and the second was a group of seven, consisting of Youth Managers or Co-ordinators from the NDM and municipalities within it. The last group was the group of national experts including the NYDA, COGTA, SALGA and GIZ-Strengthening Local Governance Programme.

It is recommended by Leedy (2005: 147) that the duration of the discussions should range between one and two hours. It must be noted that there is an apparent disagreement between Creswell (2008:181) and Leedy (2005: 146) on how many participants the focus group discussions should have. Creswell (2008:181) states that there should be "six to eight interviewees in each group", while Leedy (2005:146) advises that the number of participants "usually [is] no more than 10 to 12." 


\subsubsection{Research Population and Sampling}

The population for the study is composed of 7 youth development managers, the NDM Executive Mayor, the Municipal Managers, the municipal official responsible for performance management in the NDM, a Member of the Mayoral Committee responsible for youth development and 7 leaders of the South African Youth Council within the Nkangala District Municipality. In total, the research population is composed of 18 people.

Due to the small size of identified participants, the study was based on purposeful sampling. The total number of identified participants is more or less in the region of the theoretically prescribed number of participants for a qualitative study.

\subsubsection{Reliability and Validity and Generalisation}

The researcher ensured that data were properly transcribed, recorded and filed. These data sets were compared to each other. This allowed the researcher to revisit the data to ensure that there are no mistakes.

Validation of the data was taking place throughout the stages of data collection. During the analysis stage, the themes were validated through triangulation of the findings from the literature review, findings from the interviews and the focus group discussions.

Local government in South Africa is highly standardised through legislation. The expectations from the municipalities do not differ substantially from one municipality to another. Youth development concerns are almost common for all the youth populations in South African municipalities. This suggests that the findings of the study could be generalised to all the municipalities. This will, however, as the theory recommends, require more municipalities as case studies (Creswell, 2009:193).

\subsection{Research Data Analysis}

The study was undertaken using the qualitative approach and its data-collection methods were driven by the researcher's set of beliefs. This worldview is generally described as a pragmatic world view, a view informed by actions, situations and consequences. The study was more about moving towards finding more pragmatic ways of ensuring that youth development delivers to the expectations; thus the researcher used the qualitative methods of analysis to process the data to arrive at conclusions.

Owing to the exposure and experience of the researcher with the municipality under consideration, it could have been easier to rely on his impressions and intuition. However, as cautioned by Dey (2005), more rigorous and logical procedures were employed in analysing the data. In this case analysis meant breaking down the chunks 
of data into bits and classifying those bits to make sense of the research objectives. The analysis will be done through an identification of statements that relate to the topic, grouping statements into meaningful units, seeking divergent perspectives and constructing a composite, as argued by Leedy (2005).

In keeping with Cresswell (2009), the data will be analysed using the data analysis spiral approach. Using this approach would take one through the data several times. It is important to note that after the data have been collected, a due process of analysis will follow. The following diagram explains the process that was undertaken to analyse the data in this study.

Figure 12: Qualitative Data Analysis (QDA) Process

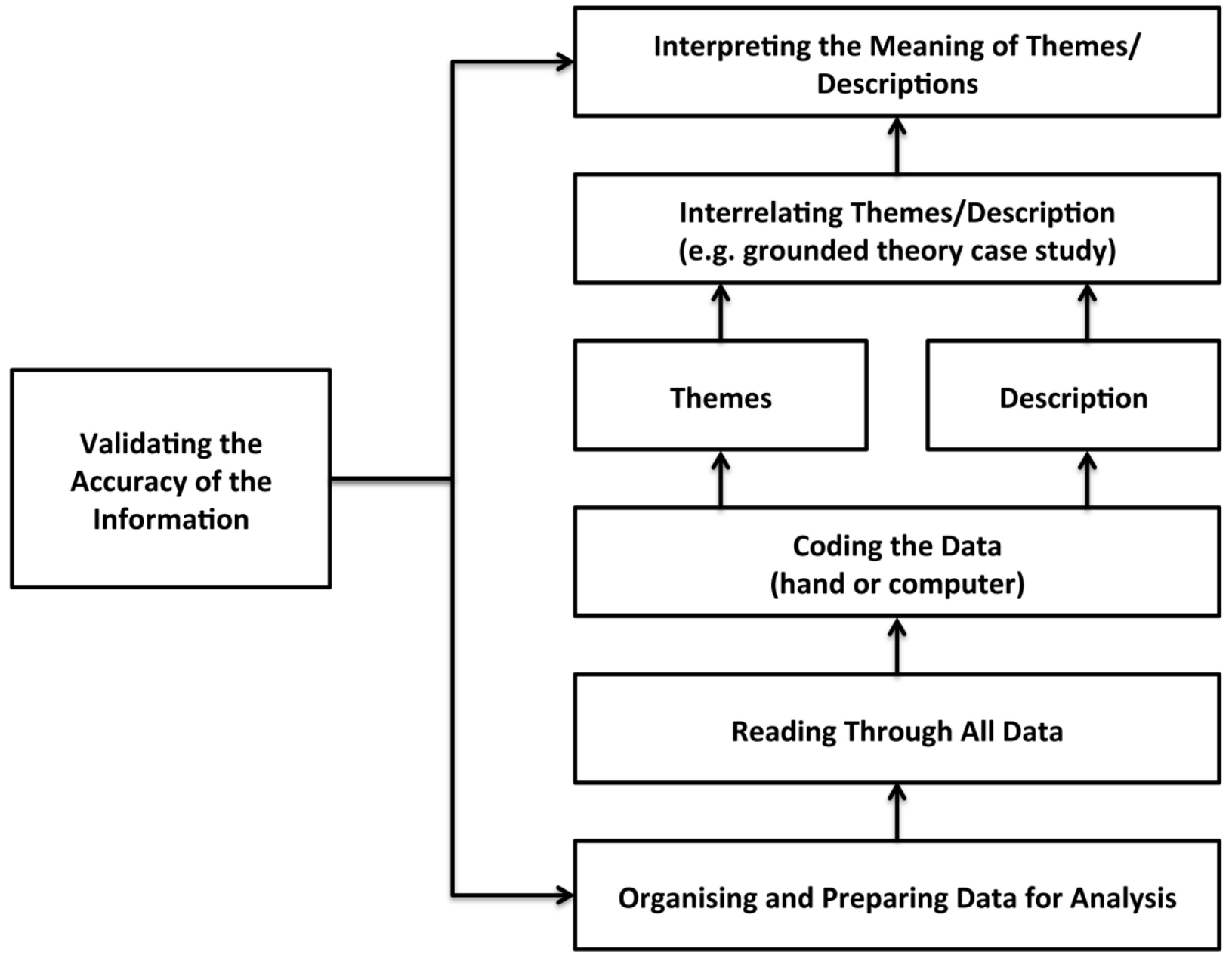

Source: Creswell (2009: 185)

According to Dey and Wong (2005), there are mainly three stages of data analysis befitting the analysis of the qualitative data. These stages are classifying, describing and connecting. Dey and Wong (2005) argue that these components of qualitative analysis are interdependent and further state that: 
We break down the data in order to classify it, and the concepts we create or employ in classifying the data, and the connections we make between these concepts, provide the basis for a fresh view.

Cresswell (2009) further breaks down these components into more steps. This is what guided the analysis in the study. He argues that there are basically six steps in analysing the qualitative data, which he explains as follows

\section{Step 1: Organise and Prepare Data}

This is the transcribing of notes out of the interviews, tape recordings and discussions. It also involves sorting and arranging data into different types.

\section{Step 2: Reading Through All Data}

The researcher used this stage to understand what the participants were saying, generally. He attempted to establish a general sense from responses by the participants.

\section{Step 3: Coding the Data}

The researcher organised data into chunks using codes that were dynamic, i.e. allowing codes to emerge during the analysis process.

\section{Step 4: Identify Themes and Descriptions}

The researcher used the codes that came out of the data analysis process to provide a description of the study settings. This was done through rendering information about the people, places and events.

\section{Step 5: Themes and Description Interrelations}

This is the advancement of how the descriptions and themes would be represented in the narrative.

\section{Step 6: Data Interpretation}

This was the final stage, used to derive meaning out of the data in relation to the study.

\subsection{Conclusion}

The study methodology was informed by the researcher's worldview, the pragmatic world view. The methodology employed was the qualitative approach underpinned by the case study of Nkangala District Municipality. The qualitative procedures and tools were employed in the collection and analysis of data.

The study was limited to Nkangala District Municipality. The researcher used both primary data collection methods: focus group discussions and semi-structured interviews, and primary data-collection methods: document review and literature review. 
The researcher employed the qualitative data analysis methods in his quest to construct a meaningful explanation of the data collected. These methods are based on logical steps, yet the procedure is like a multiple spiral. This means that the steps are revisited to ensure synergy and congruence in the study. The analysis of data in the study was basically undertaken through six steps. The steps are: organise and prepare data, read through data, coding data, identify themes and descriptions, interrelate themes and descriptions, and data interpretation. 


\title{
CHAPTER 6: ANALYSIS OF DATA AND RESULTS
}

\begin{abstract}
"Just as the Eskimos distinguish varieties of white, so researchers distinguish varieties of qualitative analysis. There is no one kind of qualitative data analysis, but rather a variety of approaches, related to the different perspectives and purposes of researchers."
\end{abstract}

(Dey, 2005).

\subsection{Introduction}

Guided by the research methodology, the researcher conducted one-on-one interviews with nine (9) experts. These interviews were conducted with the youth development managers or coordinators, the deputy manager of planning and development, and the performance management systems (PMS) manager. These experts were employed by the Nkangala district municipality and other municipalities within the district.

All the targeted participants for the one-on-one interviews responded with the exception of the district executive mayor and the municipal manager of NDM. The contribution that would have been made by these officials was thus substituted with that of the deputy manager of planning and development and the PMS manager.

Additionally, three focus group discussions were conducted. The first focus group was held with the youth development managers or co-ordinators from the district and local municipalities, while the second focus group discussion comprised the local South African Youth Council (SAYC) leadership, represented by at least one leader per local municipality and district municipality. These two focus groups were facilitated by the researcher and moderated by an independent moderator. The third and last focus group discussion was conducted with experts in youth development at the national level. The participants included representatives from the National Youth Development Agency, the GlZ-Strengthening Local Government Programme and the South African Local Government Association (SALGA). The third and last focus group was facilitated by the University of Pretoria.

This chapter presents the views, experiences and perceptions of the participants. It focuses on youth development and performance management within the studied municipalities, specifically in relation to the research questions and objectives. The approach adopted by the researcher in presenting this chapter, firstly, is presentation of the findings from the interviews and the focus 
group discussions. These findings are juxtaposed against the framework defined in theoretical terms by the frameworks identified in the literature review - as detailed in Chapters 1 and 2. Furthermore, as this analysis is conducted, gaps are identified and highlighted. This chapter is also structured in terms of the three research objectives and their related questions. The research questions in this chapter are converted to thematic issues responding to the identified research aim.

\subsection{Profile of the Participants}

Chapters 1 and 4 detail the targeted research participants, 18 in total. They included the executive mayor, the municipal manager, youth development managers or co-ordinators, local leadership of the South African Youth Council (SAYC) and officials responsible for performance management. All participants took part in the interviews, with the exception of the district executive mayor and municipal manager. The researcher added along the way the official responsible for performance management in the district.

Most of the participants who took part in the study were below the age of 35 years. Less than one third of the participants were female, owing to Emakhazeni and Thembisile Hani Municipality employing females as youth managers. All participants have at least completed high school and are in possession of a tertiary qualification. Even though others did not have qualifications in youth development or development in general, about $60 \%$ of the participants hold a tertiary qualification or are pursuing a qualification in public administration and youth development. The professional experience of the participants in relation to youth development ranges between 3-8 years. This experience ranges from the civic organisations to municipalities.

Section B of the interviews schedule (Appendix A) was aimed at probing the thoughts and experiences of the participants, focusing on the youth development experts from the studied. Evidence from their responses indicates a fair understanding of youth development. It was also found that more work still needs to be done in relation in improving the capacity of the youth development managers within the Nkangala District Municipality. Their understanding of the challenges faced by the young people in the NDM was also tested. Certainly, there is a need for instilling the culture of research, especially in relation to socio-economic issues and statistics with specific reference to the youth. 


\subsection{Youth Development and Youth Development Planning}

This section the study assessed the understanding that participants had of the youth development planning processes, specifically focusing on how planning takes place within local government. It further honed in on the youth development planning process undertaken by the NDM.

\subsubsection{Defining Youth and Youth Development.}

This section thus details the understanding that participants had of the concept of youth development. This understanding is also detailed according to the manner in which youth development is institutionalised, through the processes of planning within the NDM.

The interviews revealed that there is no singular understanding of 'youth' and 'youth development' among the participants, as the definitions varied from one participant to the other. However, all the stated definitions by participants reflected different elements of the national policy definition.

Mzwakhe: "Youth development is a process of changing the lives of the youth for better"

Phindile: "It is about improving opportunities for the young people"

Lawrence: "Youth development is creating a conducive environment for the local youth to live, for example education, work, health care, economic opportunities"

The above definitions are aligned to the study definition of youth development as detailed in Chapter 3. This is because Chapter 3 concluded that youth development is both an outcome and a process. From a process point of view, youth development is concerned with equipping a young person navigate and overcome the multiple yet inevitable challenges of adolescence and adulthood, especially in a context of widespread poverty and high unemployment. Procedurally therefore, youth development is about the financial, social and psychological empowerment of a young person. This definition was confirmed during all the focus group discussions.

Two types of age definitions of youth emerged from the interviews, with variations regarding the starting point of the age group. Two participants in the interviews used the age definition of 18-35 years to describe youths, while other participants stated the age definition as 14 to 35 years. The starting age variation in the youth definition was resolved in the focus group discussions, 
where all participants agreed that the correct definition was the one of between 14 and 35 years, since it was also legislated in terms of terms of the National Youth Policy 2009-2014 (RSA,2008b). A segmented version of the youth age definition categorises youths into three age cohorts, namely 14 to 17 years teenage group; 18 to 24 - youth group, and 25 to 35 - young adults (SALGA, 2007).

\subsubsection{The Nkangala District Municipality Youth Development Approach}

In this section the researcher aims to establish whether there is a youth development approach for the NDM and its local municipalities. This was based on the outcome in the literature review as reflected in Chapter 3.

The South African national level adopts an integrated and holistic approach to youth development. The integrated and holistic approach to youth development is principally based on the appreciation of young people as having unexplored potential. This means that the youth age category is to be seen as rich of opportunities and treasure ready to be nurtured to its full potential. The approach recognises the need for diversity and redress in development programming. It applies a life-cycle approach which places emphasis on addressing the multiplicity of challenges and needs stemming from different life stages. Appropriately, this approach ensures that youth development is seen as part of community development - in which the community and its assets are developed simultaneously (UYF, 2005).

The findings indicate that most of the participants were ignorant of the existence of a municipal youth development approach. They were also ignorant on whether their respective municipalities had devised or produced a youth development approach. In fact about $66 \%$ of the participants could not reflect or detail a youth development approach. The exception was with Bongi from Thembisile Hani local municipality and Phindile from Emakhazeni local municipality, who stated that they try to use their common sense or whatever they know to address youth development. 'Common sense' according to them was and remains undocumented. Maubane from the NDM shared that the district used the national approach of integrated and holistic youth development.

In his own words, Maubane, Acting Youth Development Manager at NDM, indicated the following: 
"The youth development approach adopted by the Nkangala District Municipality is the one encapsulated in a number of national policies. This refers to an integrated and holistic approach to youth development. It is further explained as an approach of the crosscutting nature of youth development. Young people are part and parcel of the society, therefore their development pertains the broader societal development."

Marcus, the participant from Steve Tshwete Local Municipality, described their approach to youth development as:

"An approach which prioritises the education and training of the youth. Steve Tshwete Municipality opted for this because of the belief that all other interventions are dependent on this."

The described approaches by Maubane and Marcus are consistent with the literature on youth development. This assertion by Maubane was confirmed by the deputy manager: planning and development at the Nkangala District Municipality, Mr Raputsoa. He argued that youth development is a cross-cutting issue, thus in all the municipal key performance areas the District strives to also address youth concerns.

\subsubsection{Youth Development Focus Areas in the Nkangala District Municipality}

In assessing the primary needs of young South Africans, the National Youth policy (2008b) states that youth development programmes must focus on identified vulnerable youth groups. It defines vulnerable youth groups as women, youths with disabilities, and those living in the rural areas and heading households Additional dimensions of youth vulnerability are defined as youths who are in and out of conflict with the law, at risk of HIV/ AIDS, abusing drugs and other substances.

Interviews revealed that the main focus of youth development in NDM is on unemployed youth (including graduate unemployment), young people abusing substances, rural youths, youths in conflict with the law and HIV/AIDS-affected or infected youths. For example, these were the participant responses:

Mzwakhe: "Our main focus is on youth in conflict with the law, rural youth, child headed households, unemployment youth, in school youth".

Marcus: "We focus mainly on education, then health and wellbeing, substance abuse, sport and arts and recreation". 
Mandla: "At Emalahleni, we focus on paying registration for new students, environmental management and the youth, municipal infrastructure maintenance projects".

Phindile: "At Emakhazeni, for youth development, we focus on skills development, job creation, safety and security, education and social development".

Bongi: "Youth in business, youth and health issues, youth in school and youth out of school, rural youth and the unemployed youth".

From the above, it is evident that the municipalities within the Nkangala District Municipality prioritised issues around economic participation, specifically job creation and business opportunities. There is also a strong focus on education and skills development. There is an attempt to respond to the market opportunities presented by the municipalities, local economic industries such as Mines, Eskom, Tourism, Retail and Transport. There is no evidence of any focus on the agricultural sector and agro-processing, especially in municipalities endowed with the potential for a thriving agriculture and agro-processing such as Victor Khanye, Emakhazeni, Thembisile and Dr J.S Moroka.

The evidence presented also suggests that the Municipality pays inadequate or no attention to employed youth, youth-headed households and young people living with disabilities.

A new dimension of youth vulnerability, omitted by the National Youth Policy, is one of youths living on the streets. This was described by Phindile from Emakhazeni, who argued that there is an unprecedented increase in the number of streets kids found in Emakhazeni.

\subsubsection{Youth Development Planning}

Youth development, like all other forms of socio-economic development, relies wholly on development planning for guidance and implementation. For the stakeholders involved in development, ranging from donors to practitioners, solid and measurable development plans must be formulated, implemented, measured and improved.

The findings point out a lack of evidence of purposeful plans in place for youth development in the municipality. The findings presented here suggest that indeed youth development planning in the municipalities within the Nkangala 
District Municipalities is either weak or non-existent. Three of the respondents indicated in the interviews that their municipalities never attempted to develop a youth development strategy or plan due to budgetary constraints. Four of the municipalities, including the District Municipality, had developed their strategy through consultants, but never obtained approvals or ratification of these strategies from their respective municipal councils.

According to the findings, all these municipalities provided for some form of youth development projects to be included in the IDPs; however, these were projects very shallow and narrow in scope and focus. The IDP structure should be such that it allows for a dedicated issue on youth development.

It was also found and raised as a matter of concern that during the IDP public consultative meetings often referred to as "Mayoral Imbizo's," the youth would attend in large numbers but fail to raise fundamental youth development issues for inclusion. This may provide some answers as to the nature, scope and focus of the projects that are eventually added in the IDP. The comments below indicate how some of the participants reflected on this subject.

Mandla: "Currently there is no youth development strategy in our municipality, but it is budgeted for in the next financial year. So we will be do it".

Bongi: "We have developed a local IYDS but it was not approved by the municipal council. There were no reasons given for the delays. Only the IDP contains some issues of youth development and not the Local Economic Development plan, as it does not exist".

Phindile: "We do not have the IYDS. It was budgeted for but never sanctioned due to cash flow problems. We have attempted to cover youth development matters in the IDP".

These responses by the individual participants were confirmed during two of the focus group discussions. The focus group discussion held with youth experts and by the South African Youth Council leadership in the District and local municipalities identified a need for proper and sound youth development plans. They discouraged the ad hoc inclusion of youth development issues, as was currently done in the IDPs.

The need for planning is confirmed in the National Youth Development Agency's Act (RSA, 2008a) as well as the National Youth Policy (2008b), where it 
directs for the development of the Integrated Youth Development Strategy. For local government this process will have to consider the Integrated Development Planning framework and process as stated by the Municipal Systems Act and the Municipal Planning and Performance regulations (RSA, 2000; RSA, 2001b).

\subsubsection{Youth Development and the Municipal Development Planning}

Mr Raputsoa responsible for the Integrated Development Planning process was interviewed because his function provided a deeper understanding of the planning process in Nkangala District Municipality.

From the document review it was found that youth development is addressed in some form or another in the Integrated Development Planning process. Similar to the disparities found in the age definition of youth, municipalities further interpreted the inclusion of youth development disparately. There was no uniform or standardised manner in which youth development was conceptualised and included in the IDP process. For example, some municipalities located youth development under public participation, whilst others addressed it under Local Economic Development (LED). The Local Economic Development plans in the Nkangala District Municipality omit youth development. Despite the absence of conscious and intentional planning for the youth, the argument put forward was that LED strategies would contain projects and programmes that would benefit the youth in any case.

Even though these Integrated Development Plans indicate that municipalities must develop Local Integrated Youth Development Strategies, the researcher could not establish any seamless alignment of the Integrated Development Planning, Local Economic Development and the Integrated Youth Development Strategies. For instance the Integrated Development Plan would have six KPAs such as the Local Economic Development, Public Participation, Good Governance, Financial Viability, Service Delivery and Infrastructure Development as well as Institutional Transformation and Organisational Development, and the Integrated Youth Development Strategy will document youth-oriented KPAs, namely Economic Participation, Health and Wellbeing, Sport, Art and Culture, Education and Skill Development. These Key Performance Areas are usually not clearly and seamlessly aligned.

The data gathered from the interviews and the focus group discussions confirm that the Integrated Development Plans of the Municipalities within Nkangala District Municipality and the District reflect on youth development. There is, 
however, an undertone of concern that youth development is not adequately addressed through the IDPs. All participants were in agreement that municipalities lack Local Economic Development plans that outrightly address youth development. Describing this they stated:

Lawrence: "The Integrated Development Planning does include youth development issues. But the Local Economic Development plans do not. The Integrated Development Planning outlines projects on youth development to be carried out by the Municipality during the duration of their term in office. These projects will include for example, youth summits, campaigns (HIV/AIDS) and can be noted that all these projects are not really tangible".

Mandla: "The youth development matters are captured under the Integrated Development Planning issues. It covers mainly environmental project, infrastructure maintenance projects et cetera".

Phindile: "Young people do not real youth development issues during the Integrated Development Planning Indabas. But they focus on broad municipal challenges like housing, water and electricity. The Integrated Development Planning covers some matters of youth development but not Local Economic Development strategy".

Maubane: "The Nkangala District Municipality has an issue focused on youth development and identifies projects and programmes aimed at Job Creation, business opportunities, skills development and training"

According to Raputsoa, the district is aware that the youth constitute the largest population group in the district, thus the deliberate attempt to be biased when planning for the district. He indicates that in the Integrated Development Planning, for instance, bias in all the Key Performance Areas is towards the youth, including public participation matters.

According to the focus group discussions with national youth development experts, care should be taken not to pin youth development to plans and programmes which cannot be implemented. More so, youth development must be integrated into the work of all municipal departments as a cross-cutting issue.

\subsection{Youth Development Performance Management}

This section details the findings of the focus groups conducted with youth development experts and the South African Youth Council local leadership. 
Additionally, it further details the interview findings arising out of the responses to the research question: "Is the District Municipality making use of the Performance Management System for Youth Development?

\subsubsection{Performance Management Framework}

The Municipal Systems Act directs municipalities to develop and adopt Performance Management Systems that are commensurate with their resources, and promote the culture of performance between staff, leadership and the community (RSA, 2000). Because these requirements were stated too broadly, guidelines were put in place in an attempt to clarify and simplify the provisions of MSA(1) (Roos, 2009). These guidelines consist of the following components:

- Performance planning;

- Key performance indicators;

- Implementation and monitoring;

- Performance measurement;

- Performance reporting;

- Performance improvement.

As stated earlier in this report, Figure 5 depicts the relationship between different components. Thus, it can be deduced that the framework meets the requirements for a performance framework as required in the Municipal Systems Act as well as in the Planning and Performance Management Regulations. It was found that all the municipalities have developed and adopted both the Performance Management Systems and the Frameworks.

One of the performance management models available to municipalities is the Strategic Municipal Scorecard, comprising the stated resource management, service delivery, development and the governance perspectives. All these are considered within the context of the Municipality as an organisation and as the municipal area (RSA, 2001). Again, the most applied model is the Balanced Score Card, which includes the financial, customer, internal business, innovation and learning perspectives.

The findings reflect that all the municipalities in the District applied the BSC. This included the District Municipality. According to Selapyane, there are discussions to move towards employing the strategic Municipal score card. This is mainly due to the limitation that the BSC has on the financial aspect in relation to developmental local government. The Strategic Municipal Scorecard, on the 
other hand, is specifically designed for the local government environment and particularly the developmental nature of the municipalities.

The participants argued that their municipalities do not have a Performance Management System or Framework. They even argued there is no Performance Management in place when at the same time they reported that their municipalities have the SDBIPs in place. According to the evidence presented, some municipalities were not utilising the performance management systems and frameworks to the fullest capacity. This is especially in relation to youth development. Only the Youth Development Manager from Steve Tshwete had signed a performance contract. Only Municipal Managers would have youth development issues covered in their performance plans. Municipalities had some youth development issues covered in the organisational performance plans (SDBIP). In their own words, the participants gave the following responses:

Bongi: "Thembisile Hani Municipality does not have a performance Management Systems; even the framework was never implemented".

Mzwakhe: "Yes, there is a performance management system and framework at Victor Khanye Municipality but it is not implemented to the fullest".

Marcus: "At Steve Tshwete we have a performance Management system and it is implemented up to my level as the Youth development Manager".

Phindile: "I cannot say we have a Performance Management system or framework. For example, few days ago, we were subjected to some performance appraisal for the first time. What is even more strange is that it was conducted by the full time Councillors including the Mayor and the Speaker, without the municipal manager".

Mandla: "At Emalahleni, we have no Performance Management framework that I am aware of, but we gauge performance against the SDBIPs".

The reviewed documents reflect that there are Performance Management Systems and Frameworks in the Nkangala District Municipality and the local municipalities. But these frameworks are not cascaded further down the staff levels, with limited capacity being the main reason. 


\subsubsection{Performance Management Planning for Youth Development}

Most of the experts who participated in the stud, alluded to the fact that they lacked Performance Management Plans in place. However, the literature review in Chapter 2 suggests that the SDBIPs are actually the annual performance plans for the municipalities.

It was found that youth development performance management planning occurs as an integral part of the general municipal performance planning. The major limitation is that without adequate and appropriate youth development plans, the concomitant planning for youth development assessments becomes a challenge. This activity relies heavily on the outcomes and resolutions of youth development summits and the common sense of the youth development managers, which may not be altogether common or standardised.

A minimal rate of participants confirmed the involvement and consultation of youth and youth organisations during the stage of performance planning. Thus, in the spirit of the democratic principle of public participation, Emalahleni and Steve Tshwete indicated that they consult the youth through youth indabas, where they present drafts performance measures. The rest of the other municipalities could not confirm youth participation for this critical stage. All participants agreed that the challenge in youth participation is mainly dealing with mass participation. It is much more simple to consult with the structures of youth development like the SAYC and NGOs.

Evidence also shows that there is a need for the intensification of the mainstreaming of youth development in the local government agenda. This should be carried out specifically during the planning and performance planning stage. This would ensure that all municipal departments treat youth development as a cross-sectional development concern.

It was also found that there is a need for the alignment of the youth development planning process with the Integrated Development Planning process, clarifying how the youth development KPAs fit and align with the KPAs of the municipalities' IDPs.

Maubane reported that in the district the mainstreaming of youth development occurs at the stage of developing the SDBIPs and Individual Performance Plans. At this stage the district municipality will ensure that all the departments in the district have performance targets on youth development to address. 
All participants agreed during the focus group discussion that municipalities do have performance plans (SDBIPs) derived from the IDPs which include, amongst others, youth development issues and particularly KPIs and targets.

The municipal performance and planning regulates the development of municipal performance plans. It is upon this basis that performance will be evaluated. Performance plans are required particularly at the individual level, whilst SDBIPs are required at the organisational level, (RSA, 2000; RSA, 2006).

Mrs Selapyane from the District indicated that in responding to the new Planning and Performance Management Regulations, 2006, the performance unit gets involved as early as during the municipal planning (IDP) process. This is then immediately followed by the performance planning process, which entails the development of the institutional plan (SDBIPs) and the performance plans for individuals.

It was also found that youth development matters form an integral part of the broad municipal development plans at both the IDP and the SDBIP levels. Though the extent to which the youth development matters are included in the IDPs and the SDBIPs strongly depends on the level of interest and participation by the youth during the planning process, the district always tries to go an extra mile by advertising, and inviting public comments and inputs.

\subsubsection{Youth Development Issues and Performance Plans}

As it was noted earlier on, the SDBIPs are the performance management plans at the organisational level of the Municipality. For all the SDBIPs of the Nkangala District Municipality and the municipalities within it youth development is addressed, informed by the fact that youth development issues are captured and addressed in the IDPs. The respondents had the following to note:

Maubane: "Youth development issues were covered adequately in the SDBIP, which was informed by the IDP of the district".

Mzwakhe: "There are few issues or projects on youth developments covered in the IDP, and the same with the SDBIP of Victor Khanye Local Municipality".

Bongi: "The SDBIPs only covers youth development issues to the extent defined in the IDP". 
Mandla: "This is the challenge in our municipality, because Section 57 managers still see youth development as foreign to their mandate and scope".

Marcus: "All the organisational level, the SDBIP covers youth development issues".

Phindile: "Youth development is covered in the SDBIP and individual performance plans e.g. education, health, youth participation, social transformation, job Creation, and safety and security".

Evidence suggest that because at the stage on municipal planning, very little is said about youth development concerns, it creates a challenge when it comes to the stage of including adequate targets for youth development in the Performance Management Plans (both SDBIPs and Individual performance plans). These issues are confined to events and campaigns, job creation, skills development, internships and learnerships, business opportunities and education financial support.

According to Mrs Selapyane, at the Nkangala District Municipality youth development issues are properly defined in the IDP and the draft Youth Development Strategy; thus it becomes easier to define the same during performance planning and inclusion in the SDBIP and the performance plans. Section 57 managers are expected to sign contracts that inter alia define youth development measures.

\subsubsection{Individual Performance Plans and Youth Development Targets}

Evidence shows that Individual performance plans are developed from the SDBIPs as directed by the individual performance contracts. In all municipalities the inclusion of youth development measures are limited to municipal managers, with an exception to Steve Tshwete where it is cascaded to the level of the youth development manager.

Evidence from the participants is recorded as follows:

Mzwakhe: "Youth development targets are not clearly defined in the performance contracts and plans of the MM, Section 57 and the Youth Development Manager. The Youth Development Manager does not even have performance contract". 
Bongi: "At Thembisile Hani, we do not have performance agreement. They are still in draft form. Even the municipal manager does not have clear targets on youth development".

Lawrence: "Only the municipal managers have youth development targets in his score card. Myself as the Youth Development Manager, I do not have even a performance contract".

Phindile: "It is the only municipal manager contract and Performance Plan that covers youth development targets. Other managers including section 57 managers and myself as the manager: Youth Development, we do not have. Myself I don't have a contract except for the SDBIP".

Maubane: "Currently, we do not have a Youth Development Manager. I am acting, but it we had one, there would have been a performance contract with clearly defined targets. Our Municipal Manager and all managers reporting to him have contracts covering youth development issues".

There was also an agreement that performance measurement especially at the organisational level in general, in particular in relation to youth development, should be defined in such a way that they respond to the development challenges and opportunities faced by the youth of the district. To this effect it was even suggested that youth development targets should take their cue from the National Development Indicators.

Respondents believed that youth stakeholder participation is a key requirement in the youth development management process. This would assist buy-in from the youth structures and the youth beneficiaries with regard to the relevance and progress made in addressing the development prerogatives. The South African Youth Council (SAYC) could play a meaningful role in ensuring youth participation in the Youth Development Performance Management process.

Mrs Selapyane confirmed that the contract of the NDM's section 57 managers and the Municipal Manager were premised on the approach of the crosscutting nature of youth development. All departments in the district had to address youth development concerns. Therefore all section 57 managers had to have youth development targets included in their performance plans.

During the focus group discussions, it was argued that although there are same targets on youth developments, there remains a need for further defining and 
standardising the youth development indicators between municipalities. Emalahleni, Steve Tshwete and the District reported that they have clearly defined youth development targets. These were the results of youth development summits they have held. Municipalities are expected to develop SMART KPIs and performance targets. The KPIs are to be developed informed by the KPAs as outlined in the IDP during the planning stage (Roos, 2009).

The group discussion with the national youth development experts confirmed the argument for the need for the inclusion of youth development as a Key Performance Area. This argument was sparked by the attitude observed in many municipalities against youth development. This could be in direct contrast to the integrated and holistic approach, as it would not be covered in other KPAs such as Local Economic Development, Service Delivery and Development, Public Participation and Institutional Transformation. There is an agreement in ensuring that the Department of Cooperative Governance and Traditional Affairs (COGTA) should work with the NYDA to enforce the focus on youth development by municipalities.

Section 41 of the Municipal System Act identifies the need for a framework that will identify appropriate KPIs with consideration of development priorities and strategic development objectives, and to measure performance targets with regards to each of those developments priorities and objectives. Performance measures: KPIs and targets are essential to assist in determining whether any programme or policy is achieving its intended outcomes. It is particularly important to set performance indicators against the objectives as this would enable the monitoring and evaluation of the progress made in terms of the development interventions (Aphane, 2000). Indicators could take any of the following types:

- Input Indicators: required resources to achieve objectives;

- Process Indictors: what needs to be done/activities;

- Output Indicators: what should be achieved/produced;

- Outcome Indicators: Quality of life, (RSA, 2001c).

Findings also show that there is no particular approach standard to all the municipalities within Nkangala District. The district's performance framework directs the district to use the outcome-based indicators at the organisational level, whilst it appears to prefer the output indicators at the individual level. 


\subsection{PERFORMANCE MEASUREMENT AND YOUTH DEVELOPMENT}

Performance measurement is generally concerned with gauging the progress towards attaining the development goals and objectives. In order to provide a firm grounding for development performance management, it is critical for the managers to define the parameters of development for measurement. Thus the determination of the Key Performance Areas and the Key Performance Indicators. These parameters are also crucial for the performance planning stage.

As recommended in the Framework for Managing Programme Performance (2007), it is important to measure performance because it gives an indication whether the development plans and programmes are carried out. As cited in the document, the following points provides more clarity on why performance measurement has to be carried out:

- If you do not measure results, you cannot tell success from failure;

- If you cannot see success, you cannot reward it;

- If you cannot reward success, you are probably rewarding failure;

- If you cannot see success, you cannot learn from it;

- If you cannot recognise failure, you cannot correct it;

- If you can demonstrate results, you can win public support.

(Osborne and Gaebler, 1992).

It is in the same spirit that participants agreed on the assertion that measuring youth development performance is the most important component of performance management.

\subsubsection{Youth development Key Performance Areas}

The tangible outcome of the Integrated Development Planning Process is a plan which has clear development goals and objectives. Once this is attained, development objectives are to be clustered in terms of Key Performance Areas. In some strategic or plans, these are referred to as Key Development Areas (KDAs) or Key Focus Areas (KFAs). These terms can be used interchangeably.

The participants informed the researcher that for their IDPs the municipalities and the District identified six KPAs:

- Local Economic Development

- Public Participation

- Organisation Transformation

- Good Governance 
- Financial Viability

- Service Delivery and Infrastructure Development.

Youth development in municipalities is part of a broad municipal development agenda. As a development programme it must have KPAs, setting the focus and parameters for youth development. At the national level the KPAs for youth development are defined as follows:

- Economic Participation: focusing on the creation of business opportunities and job creation;

- Health and Wellbeing: which focuses on the physical fitness of the youth, improving longevity of the youth (life expectancy), avoidance of communicable diseases such as HIV/ AIDS and youth in arts and sports;

- Education and Skills Development: focuses mainly in the improvement of literacy and numeracy levels, provision of skills required by the economy in line with JIPSA and the National Development Plan - Vision 2030 (RSA, 2011);

- Social Cohesion and Civic Participation: focusing on bridging the racial and economic divide amongst the youth of our society, and encouraging the participation of youths in decision-making processes. It is about nation-building interventions;

- National Youth Service: focuses on galvanising the youth consciousness with regards to community service and patriotism. It also aims at exposing youths to the world of work and provides opportunities for on-the-job experience;

- Youth Work in South Africa: the focus is on professionalising this field and ensuring that it remains an area of interest and career of choice for the youth. It involves developing a curriculum for practitioners and regulating the profession (RSA, 2012).

Participants informed the researcher that in their municipalities, they have identified KPAs for youth development, especially in those municipalities that have at least some draft Youth Development Strategies. Amongst others, the participants identified the following KPAs:

- Social Development (or Social Cohesion)

- Sports and Culture

- Skills Development

- Education

- Economic Participation 
- Health.

The following are responses from some of the participants:

Maubane: "Our KPAs as Nkangala District are National Youth Service, Social Cohesion, Entrepreneurship, Skills Development, Health and Wellbeing and a few others".

Phindile: "Emakhazeni identified entrepreneurship, health, crime prevention, but I do not have their documents as key performance areas since we do not have an Integrated Youth Development Strategy".

Mandla: "Our Key Performance Areas are economic participation, health, job creation and social development".

During the focus group discussions it was agreed that the key Performance Areas used at the national level are the most encompassing work to be carried out under youth development. It was found that the national KPAs cover and cater for all the variations evident from the municipalities under NDM including the District.

\subsubsection{Youth Development Key Performance Indicators}

According to National Treasury (RSA, 2007), for managers to define good performance indicators, they need to have a thorough understanding of what needs to be measured. Almost anything can be measured, but it is what is needed for accountability and management that must form the core of Performance Management. Key Performance Indicators could be in the form of outputs, inputs, activities, outcomes and impacts. Key Performance Indicators must also attempt to measure equity, effectiveness, efficiency and economy.

The National Treasury (RSA, 2007) further asserts that six steps could be followed in developing suitable indicators as follows:

Step 1: Agree on what problem/challenge is to be addressed and what is to be achieved;

Step2: Specify the activities, inputs and outputs; in this regard the "logic model" could be useful;

Step3: Select the most important indicators and prioritise them;

Step4: With consideration of baseline, set realistic performance targets;

Step5: Determine the process and format for reporting performance;

Step6: Establish processes and mechanism to facilitate corrective action. 
The respondents suggested that even though the KPIs for youth development are defined as informed by the IDPs, the limitation is that they are too few and they are not adequately addressing holistic youth development concerns.

According to the participants, following the IDP process is the performance planning phase which would produce the SDBIPs followed by the Individual Performance Plans. The broad development plans (IDP or IYDS), where the Municipality has one, would have defined the parameters and the focus for youth development in the form of the Key Performance Areas. It was then found that after this stage Key Performance Indicators are determined to help in the gauging of the progress in realtion to the youth development programme of the Municipality or the District.

It was evident that most of the municipalities' KPIs were inherent from the extent to which the IDP process would have defined issues and projects for youth development. The determined KPIs would be limited to the provisions of the IDP.

\subsubsection{Performance Targets for Youth Development}

When good and clearly defined Key Performance Indicators are identified, the next step is to then set performance targets. Targets are an expression of what level of performance is to be achieved. It is important to determine the baseline of previous year's achievement. In the case of the first year in the existence of the Key Performance Indicators and target, the baseline will often not be available unless market comparison or benchmarking is employed. All targets must be subjected to the test of the S.M.A.R.T principle. A target must be specific, measurable, attainable, relevant and time bound (RSA, 2007: 9 -10). In relation to youth development, the limitation has always been attributed to the absence of an Integrated Youth Development Strategy and the confusing Key Performance Areas and subsequently the Key Performance Indicators.

Evidence shows that municipalities have addressed this aspect, even though not adequately. All municipalities have defined Key Performance Indicators that were compiled with specific reference to the S.M.A.R.T criteria.

It was also found that most of the targets for youth development are expressed in percentages and in numerical terms. Very few targets are qualitative in nature. The following are examples of KPIs and targets (Table 7). 
Table 7: Example of KPAs, KPIs and targets

\begin{tabular}{|l|l|c|}
\hline Key Performance Areas & Key Performance Indicators & Target \\
\hline Education and Skills Development & $\begin{array}{l}\text { Number of young people assisted } \\
\text { with university registration fee }\end{array}$ & $10 \%$ \\
& $\begin{array}{l}\text { Number of youth owned } \\
\text { contractors trained at NQF level 2 }\end{array}$ & 1000 \\
\hline Economic Participation & $\begin{array}{l}\text { Percentage share of the youth in } \\
\text { SMME ownership }\end{array}$ & $30 \%$ \\
\hline Social Cohesion & $\begin{array}{l}\text { Number of young people } \\
\text { employed for the first time }\end{array}$ & 1 million \\
\hline & $\begin{array}{l}\text { Youth voter turnout as a } \\
\text { percentage share of total voter } \\
\text { turnout }\end{array}$ & $50 \%$ \\
\hline $\begin{array}{l}\text { Number of youth and student } \\
\text { dialogues on racial and } \\
\text { economic disparities }\end{array}$ & 100 \\
\hline
\end{tabular}

\section{Source: By the Researcher}

It was also found that at the stage of determining the targets, it can't be convincingly argued that the youth are involved. It was noted, however, that even though the youth masses are not directly involved in the determination of the targets, the targets are based on the resolutions adopted at youth summits held in the municipalities and the District, which include also local youth structures such as the South African Youth Council.

\subsubsection{Integrating Youth Measures into the IDP and PMS}

Municipalities are compelled by law to develop and adopt IDPs as single strategic plans for development for the Municipality for a period of five years. By definition these plans are all-inclusive and all-encompassing. This plan also forms the most critical basis for performance management in municipalities (RSA, 2000). Accordingly, youth development planning cannot be addressed in isolation from the IDP. It is to be expected that youth development measures will have to be integrated with the broad Municipal PMS measures. This means that youth development performance targets will have to find expression in the SDBIPs as well as in the Individual performance plans on the municipality.

The views of the participants were tested with regards to determining whether currently in the district such integration exists or not. It was found that in most 
municipalities only the municipal manager contract and performance plan would include youth development issues. In some instances also the youth development manager would have such a performance plan, i.e. Steve Tshwete. In very rare instances it was found that youth development issues and measures are found for all section 57 managers.

It was also found that there is a general challenge in cascading performance management to junior staff members in all municipalities. In all municipalities the performance management system does not apply to junior staff. Only in Steve Tshwete and the NDM have the youth development managers signed the performance contracts.

Participants were recorded as having said the following:

Phindile: "Only the municipal manager's contract and the performance plan include youth development measures".

Mzwakhe: "I doubt if, that even the municipal manager is having youth development issues in her score card".

Mandla: "Though we have youth development interventions in the various departments of the municipality only the MM has youth development measures in her score card".

Maubane: "In the NDM, youth development is treated as an issue that cuts across. It is for that reason that all directors are expected to have something on youth development. E.g. EPWP programme in the engineering services, skill training in corporate services, business opportunities at LED, this all section 57, including the MM and the youth manager would have youth development in their plans".

\subsection{Conclusion}

In this chapter the researcher presented and analysed the findings of the study, whose research questions were informed by the research guidelines outlined in the Chapter 5 . The discussions and the analysis of the findings were informed by the lessons drawn from the literature review as documented in Chapters 2 and 3 , as well by the document review of the study area. Finally, evidence from the interviews and the focus group discussions formed a strong basis for discussions.

Even though there seem to be some variations in the definition of 'youth', the common and acceptable definition is between the ages of 14 and 35 years. At the same time youth development is defined as a process of shaping the young 
towards archiving a better life, also as an outcome giving the youth the most needed interventions. This development is with special reference to youths out of school, substance abuse, rural youth, youth in conflict with the law. It is for that reason that in the Nkangala District Municipality youth development planning has now become an important agenda item.

The Municipal System Act (2000) compels municipalities to develop and adopt the Performance Management Systems and Frameworks. Thus all the municipalities withint the Nkangala District Municipality have developed systems and frameworks. Subsequently these SDBIPs have been put in place, followed by the individual performance plans, though limited to section 57 managers. Youth developments issues are to some extent included in all municipalities,

There are clearly defined performance management measures for youth development. Flowing from the IDPs process, the performance planning and youth development performance indicators are in place. In some municipalities this remains a challenge, as there is still a need for setting a proper youth development agenda and direction.

The next chapter will summarise the findings on the state of youth development performance management in the Nkangala District Municipality. It will also make recommendations on the basis of the conclusions drawn by the researcher from the study and its findings. 


\title{
CHAPTER 7: SUMMARY, CONCLUSION AND RECOMENDATIONS
}

\author{
"Focus on the journey, not the destination. Joy is found not in finishing an \\ activity but in doing it."
}

(Greg Anderson, Date unknown)

\begin{abstract}
7.1. Introduction
Undoubtedly the pressure for efficient and effective youth development programmes is increasing. More and more demands in the face of socio-economic ills are focusing on the youth. This ranges from a need to create an educated and relevantly skilled work force, to the creation of employment opportunities, to the availing of economic participation opportunities. Young people are demanding to be placed at the centre of development. In various youth development forums youths raise the need to start discussing the idea of a youth quota in terms of all the development focus areas. This pressure has brought about an increasing attempt by government departments, the private sector and, most relevant for this study, municipalities to provide interventions to address the challenges faced by the youth. The major challenge has always been, and is even more glaring now, the inconsistencies in the approach to youth development and management of the performance. Hence the need to develop youth development guidelines and a performance framework has become more relevant.
\end{abstract}

This chapter is aimed at providing a summary of the study on Youth Development Performance Management in the Municipalities: The Case of Nkangala District Municipality. In this chapter the researcher restates the rationale of the study, the problem statement and the sub-problems. It will also highlight the salient points arising out of the first three chapters, which largelyconstitute the literature review. Results from the interviews will also be highlighted. Whilst presenting the data, the researcher will also briefly highlight the methods and methodology. This chapter will conclude by putting the conclusions drawn from the study and making recommendations arising from the study.

\subsection{Summary of the Findings}

The study sought to explore the practices and approaches to Youth Development Performance Management in local government. As stated in Chapter 1 of the report, the research problem was stated as: "The absence of a tailor-made performance management framework for youth development in local government hinders the performance of youth development programmes. Inevitably, such absence affects the possibility of attaining the set targets in relation to youth development outcomes."

This problem was further broken down through the introduction of three research questions: 
- What are the factor that define the youth development agenda and youth development planning in the NDM?

- Is the NDM making use of the performance management system for youth development in the district?

- Does the municipality have clearly defined performance measures for youth development?

The theoretical basis underpinning all the three research questions is addressed in Chapters 5 and 6 . In Chapter 5 the study considered the sub-problems in the light of the available and documented information. In Chapter 6 this was tested against the responses of individuals working in the municipalities on youth development. To this end, one-on-one interviews and focus group discussions were used as methods for the empirical study.

\subsubsection{Findings on Research Question 1}

In relation to Research Question 1, it was found that there is a consensus on the definition of youth and youth development in the NDM, i.e. they are people between the ages of 14 and 35 years. Their development is concerned with their transition along the age continuum from childhood to functional adulthood. Even though it is found that most municipalities have not adopted the local Integrated Youth Development Strategies, municipal IDPs cover at a very basic level youth development matters. The NDM and its Municipalities see youth development as a cross-cutting mandate, which must be addressed within the ambit of the local government objects.

\subsubsection{Findings on Research Question 2}

In response to Research Question 2, it was found that that all municipalities have developed and adopted the Performance Management Frameworks and Systems for the business of the municipalities in general. The adoption of the system and the framework read in the context of compulsory compliance, led to the introduction of the organisational annual performance plans (or SDFBIPs as they are tagged) and the individual performance plans. These tools have not yet been fully applied to youth development, as this has not yet even cascaded to the lower level staff; it is still limited to the Section 57 managers level (RSA, 2000).

\subsubsection{Findings on Research Question 3}

And finally, in relation to Research Question 3, pursuant to the findings above, it also found that in so far as the youth development matters included in the IDPs are concerned, as limited as they might be, relevant youth development KPAs were identified, KPIs developed and performance targets were determined. Youth participation was to a very limited extent allowed for in the development of these youth development performance measures. In most municipalities the inclusion of the youth development measures was only limited to the SDBIP, municipal managers' 
performance plan and the youth development managers. Heads of other divisions were exempted from these measures.

Overall, the study found that in the NDM there is a performance management system which integrates, amongst others, youth development issues. However, due to limitations in the planning stages, few KPIs and targets are outlined for youth development. Those KPIs put in place and subjected to the performance management system positively contribute to the successful implementation, monitoring and evaluation of youth development interventions.

\subsection{General Conclusions}

From the literature review, desktop review of documents and the findings of the study, it is concluded that in order to maximise the impact of the youth development interventions employed by municipalities, the youth development agenda needs to be standardized. A common approach is required in order to measure and evaluate the performance by the municipalities in relation to youth development.

Furthermore, there is a need to adapt the municipal performance framework to accommodate the youth development programmes. This will also provide a better view of how well a municipality is performing in relation to other municipalities, allowing a comparative view of municipalities' interventions in youth development.

It is also apparent from the findings that at the moment most municipalities in the study area have not clearly defined performance measures to monitor progress on youth development. This is a result of a blurred development agenda, hence the inconsistent youth development areas of focus.

\subsection{The Limitations of the Study}

The following limitations, in relation to the study, were the identified:

The research population covered mainly the youth development experts in the NDM and its local municipalities. This is too limited a population to allow for generalisation in local government.

Most of the municipalities have not adopted their Integrated Youth Development Strategies; thus it becomes difficult to evaluate the full impact of youth development programmes.

The participants have not really internalised their own plans and policies, including understanding their youth development status quo analysis. This limited their contribution to the interviews. 


\subsection{Recommendations}

The findings of the study were considered and analysed in the light of the theories and prescripts derived from the literature review and the review of the operational documents. Based on the findings of the study, the following recommendations are made:

\subsubsection{Recommendations in relation to Research Question 1}

The inconsistencies in the approaches to youth development by municipalities suggest that there is a need to capacitate and regulate the practitioners of youth development in the municipalities. This reaffirms the call for the professionalization of youth work in South Africa.

Municipalities needs to ensure that they develop local youth development strategies which must also align with the IDPs. This will help define the youth development agenda from which the KPIs for youth development can be derived.

\subsubsection{Recommendations in relation to Research Question 2}

Municipalities needs to speed up the process of cascading the application of performance management to all the levels of their staff. The youth development unit must also be subjected to the performance management prescripts.

Municipalities must ensure that all section 57 managers include youth development measures in the score cards and ensure that in their line of work they also respond to the developmental needs of the youth.

Youth development units must lobby for the adoption of a framework that will guide youth development performance management in the municipality. Figure 13 illustrates the recommended framework.

The proposed process diagram is adapted from the Municipal Performance Management Framework. The Youth Development Performance Framework Model is based on the seven components. Five of these are steps in the process and the other two are the compulsory, repetitive and ongoing activities in the process: 
Figure 13: Proposed Youth Development Performance Management Framework

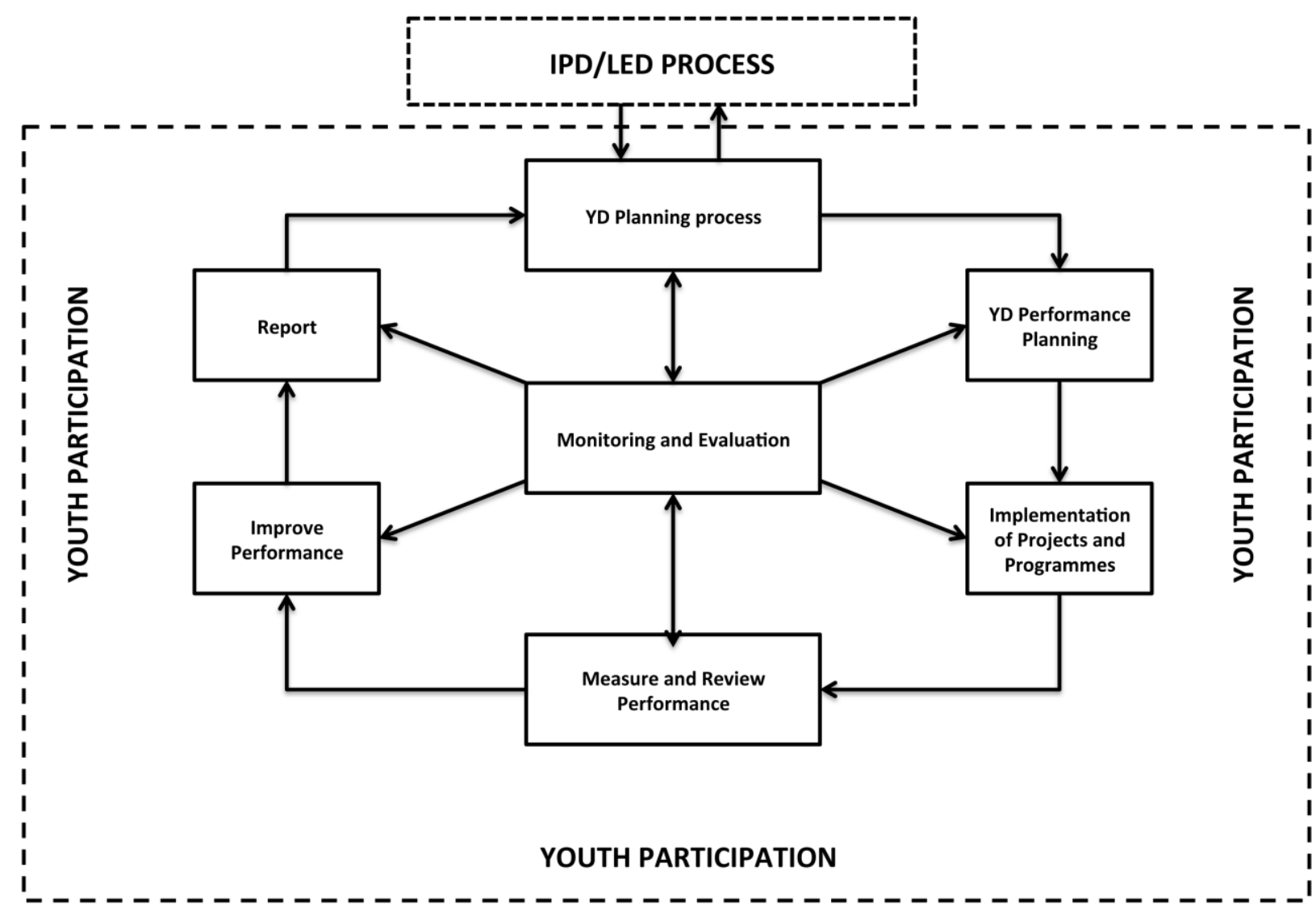

Source: Adapted from Roos (2009: 32)by the Author

- Youth Development Performance Planning: this is the first stage of the process. It is preceded by the IDP process and the youth development planning process, whose product is the definition of the KPAs, strategic objectives, and projects and programmes. This stage will determine the KPIs and the targets as the outcome.

- Implementation of Projects and Programmes: this is the stage whereby the development plan is made a reality. All the envisaged activities are put into practice and the budget is expended against the plan.

- Measure and Review Performance: this is the third stage in the process which allows for the measurement of the targets against the progress on the implementation of the KPIs and entails a review of the measures.

- Improve Performance: this is the continuation of the implementations stage which takes cognisance of the reviews performed. 
- Reporting: this is last stage in the recommended Youth Development Performance Management process. It relates to the submission and publishing of the performance report for the consumption of the stakeholders.

- Monitoring and Evaluation: this is not necessarily a stage, but it is a procedure that is performed throughout the process.

- Youth Public Participation: this is another requirement to be performed throughout the process. It is an attempt to ensure that youth stakeholders provide inputs and insights into the planning, implementation and reporting of the youth development initiatives.

\subsubsection{Recommendations in relation to Research Question 3}

There is a need to improve the policy and legislature provisions governing youth development in South Africa in order to clearly define the development agenda and to provide guidelines for youth development.

There is also a need to improve the capacity of the municipal officials to deal with youth development. Through this, the municipalities must also strive to inculcate the culture of integrated youth development.

\subsubsection{Recommendations for further research}

There is a need for a study on youth development planning. This study needs to be conducted at different levels. It must be conducted at the national, provincial and municipal levels. The study should include defining the planning framework for youth development. It also must entail alignment of the youth development plans with the national deployment plan, the provincial growth and development strategy and the integrated development plans.

Finally, there also appears to be a need for a study that will focus on assessing the capacity of youth development managers and co-ordinators against the expectations of youth development in general. 


\section{BIBLIOGRAPHY}

African National Congress (1994). The Reconstruction and Development Programme: A Policy Framework. Umanyano Publishers, Johannesburg.

African National Congress (2007). 52 nd National Conference Resolutions. Unpublished Report, Johannesburg.

African National Congress Youth League (2008). Resolutions of the $23^{\text {rd }}$ National Congress. Unpublished Report, Johannesburg.

African Union (2006). African Youth Charter. http://www.africaunion.org/root/ua/conferences/mai/hrst/charter\%20english.pdf accessed 21 June 2011.

Aphane, L.P.P (2000). Performance Management Systems in Kempton Park Tembisa Metropolitan Local council. Unpublished Master's Thesis, University of the Witwatersrand, Johannesburg.

Armstrong, M. and Barron, A. (2005) Managing Performance: Performance Management in Action. Chartered Institute of Personnel and Development, London.

Atkinson, D. (2001). Towards Performance Management in Local Government. In Coetzee, J.K. Graaf, J. Hendriks, F. and Wood, G. (eds.). Development Theory, Policy and Practice (pp. 553-566 ). Oxford University Press, Cape Town.

Brown, M.F. (2002). An Individual Performance Management System as Way of Improving Customer Satisfaction at the City of Cape Town (Unicity) Municipality. Unpublished Master's Thesis, University of Stellenbosch.

Cobbold, I. Lawrie, G. (2002). The development of the Balanced Scorecard as a Strategic Management tool. Paper presented at PMA conference, Boston, USA.

Cokins, G. (2007). Performance Management: Finding the Missing link to Close the Intelligence Gap. N. J. Wiley, New Jersey

Coldwell, D. \& Herbst, F. (2004). Business Research. Juta and Co Ltd, Cape Town.

Costello, S. (1994). Effective Performance Management. McGraw-Hill Company Inc, New York 
Craythorne, D.L. (2003). Municipal Administration. Juta and Co Ltd, Cape Town.

Curtis, D. (1999) Performance Management for Participatory Democracy: Thoughts on the Transformation Process in South African Local Government. University of Birmingham Press, Birmingham.

Dawson, C. (2007). A Practical Guide to Research Methods. How To Books. Oxford.

De Visser, J. and Steytler, N. (2009). Implications for Local Government of a single Public Service. Local Government Bulletin 1999-2008. Community Law centre, University of Western Cape, Cape Town.

Dey, I. (2005). Qualitative Data Analysis: A User-Friendly Guide for Social Scientists. Routledge, London and New York

Gallagher, S.J. (2010). Linking Individual performance Appraisal with Departmental Outcomes: Does the type of Individual Performance Appraisal System Influence Departmental Performance. Unpublished Master's Paper, University of North Carolina, North Carolina.

Ghosh, S. Mukherjee, S. (2006). Measurement of Corporate Performance through the Balanced Scorecard: An Overview. Vidyasagar University Journal of Commerce, Vol. 11:60-70.

Haldenwang, B. (2012). Strategic Insights Repot: Crime trends in South Africa 1994-2012. University of Stellenbosch, Stellenbosch

Harrowgate Baroughn Council (2006). Performance Management Framework. www.harrowgate.gov.uk/documents/performancemanagementframework. Accessed 29 October 2011.

Jantjes, A (2008). An Analysis of Organisational Performance Management in the City of Cape Town: From Legislation to Implementation. Unpublished Master's Thesis, University of Stellenbosch.

Kaplan, R. \& Norton, D. (2006). Alignment: Using the Balanced Scorecard to Create Corporate Synergies. Harvard Business School Publishing Corporation, Boston.

Keys, J. (2005). Implementing the IT Balanced Scorecard: Aligning IT with corporate strategy. Auerbach Publication, Boca Raton. 
Leedy, P.D. (2005). Practical Research: Planning and Design (8 ${ }^{\text {th }}$ Ed.). Pearson Prentice Hall, New Jersey.

Locket, J. (1992). Effective Performance Management. A Strategic Guide to Getting the Best out of People. Kogan Page Ltd, London.

Mail \& Guardian (2011). Arab Spring anniversary shows youth uprising gone global, http://mg.co.za/article/2011-12-17-arab-spring-anniversary-reminds-us-of-youth-uprising/. Accessed 20 December 2011.

Marwala, T. (2006). Foundations for a Developmental State: A Case for Technical Education. University of Johannesburg, Johannesburg.

Merriam-Webster Dictionary. (Undated). http://www.merrian-bester.com/dictionery/framework. .Accessed 28 June 2011

Mouton, J. (2008). How to Succeed in Your Master's and Doctoral Studies: A South African Guide and Resource Book. Van Schaik, Pretoria.

Nealer, E. (2007). Human Resource management in Van der Waldt, C. (ed.) Municipal Management: Municipal Human Resource Management. Juta and Co Ltd, Cape Town.

Nkangala District Municipality (2008). NDM Spatial Development Framework 2008. Steve Tshwete.

Nkangala District Municipality (2009). Integrated Development Plan 2009/2010. Steve Tshwete.

Nkangala District Municipality (2010a). NDM Annual Report 2009/2010. Steve Tshwete.

Nkangala District Municipality (2012). Integrated Development Plan 2012/2013. Steve Tshwete.

Nkangala District Municipality (2012). NDM draft Integrated Youth Development Plan. Steve Tshwete.

Osbourne, D. and Gaebler, T.(1992) Reinventing Government: How the Entrepreneurial Spirit is Transforming the Public Sector From Schoolhouse to Statehouse, Addison Wesley Publishing Company, Washington. 
Oxford Dictionaries. (Undated). http://oxforddictionaries.com/definition/framework Accessed 28 June 2011.

Pelser, E. (2008). Learning to be lost: Youth Crime in South Africa. Centre for Justice and Crime Prevention, Cape Town.

Phala, D.R. (2007). Institutional Aspects of Performance Management for Greater Sekhukhune District Municipality Unpublished Master's Thesis, University of Witwatersrand, Johannesburg.

Pollitt, C. and Bouckaert, G. (2011). Public Management Reform: A Comparative Analysis: New Public Management, Governance and the Neo-Weberian State. Third Edition. Oxford University Press. Oxford

Ravhura, M.E (2006). Performance Management in the Department of Education with a special reference to the Limpopo Province, University of South Africa, Pretoria

Republic of South Africa (1996a). Constitution of the Republic of South Africa (Act 108 of 2000). Government Printers, Pretoria.

Republic of South Africa (1996b). National Youth Commission Act (Act 19 of 1996). Government Printers, Pretoria.

Republic of South Africa (2000). Municipal System Act (Act 32 of 2000). Government Printers, Pretoria.

Republic of South Africa (2001a). Municipal Finance Management Act Circular Number 13. National Treasury, Pretoria.

Republic of South Africa (2001b). Municipal Planning and Performance Management regulations(R 769 of 2001). Government Printers, Pretoria.

Republic of South Africa (2001c). Performance Management Guide for Municipalities. Unpublished Report. Pretoria, Department of Provincial and Local Government.

Republic of South Africa (2003a). Municipal Finance Management Act (Act 56 of 2003) . Government Printers, Pretoria.

Republic of South Africa (2003b). Municipal System Amendment Act (Act 44 of 2003). Government Printers, Pretoria. 
Republic of South Africa (2006). Municipal Performance Regulations for Municipal Managers and Managers Directly Accountable to Municipal Managers (R805 of 2006). Government Printers, Pretoria

Republic of South Africa (2008a). National Youth Development Agency Act (Act 54 of 2008). Government Printers, Pretoria.

Republic of South Africa (2008b). National Youth Policy 2009-2014. Government Printers, Pretoria.

Republic of South Africa (2009). State of Youth Development Practice in South Africa. Unpublished Research Report. Department of Social Development, Pretoria.

Republic of South Africa (2010). National Antenatal Sentinel HIV \& Syphilis Prevalence Survey Report 2009. National Department of Health, Pretoria.

Republic of South Africa (not dated). Introduction to Performance Management for Local Government in South Africa. Government Printers, Pretoria.

Republic of South Africa(2007). Framework for Managing Programme Performance Information. National Treasury, Pretoria.

Republic of South Africa(2012). South African Status of the Youth Report 2012. National Youth Development Agency, Midrand.

Roos, M. (2009). Performance Management within the parameters of the PFMA. Unpublished Masters Thesis. University of South Africa, Pretoria.

Silatech (2011). The Arab Spring- Implications for the Youth Development Agenda.http://www.silatech.com/index.php?option=com content\&view=article\&id=391:pressrelease-the-arab-spring-implications-for-the-youth-development-agenda\&catid=10:newsarchive\&Itemid=171. Accessed 22 November 2011.

United Nations (2005). World Youth Report 2005: Young people today and in 2015. United Nations, Geneva.

Van der Waldt, C (ed.) (2007). Municipal Management: Municipal Human Resource Management. Juta and Co Ltd, Cape Town.

Van Der Walt, G. (2004). Managing Performance in the Public Sector: Concepts, Considerations and Challenges. Juta \& Co. Ltd, Lansdowne. 
Walsh, D. (2010). World Socialist Web Site: Food riots erupt in Mozambique. http://www.wsws.org/articles/2010/sep2010/moza-s04.shtml. Accessed 21 December 2011

Warden, B. and Wong, S. (2007). Introduction to Qualitative Analysis. Unpublished Paper.

Welman, C. Kruger, F. \& Mitchel, B. (2008). Research Methodology. Oxford University Press, Cape Town. 
APPENDIX A: QUESTIONS FOR YOUTH DEVELOPMENT EXPERTS 


\section{Youth Development Performance Management}

Interview Schedule

For YD Managers or Coordinators,

\section{SECTION A: PARTICIPANT'S BIOGRAPHY}

\begin{tabular}{|l|l|}
\hline Name of Interviewee: & \\
\hline Organisation & \\
\hline Position Held & \\
\hline Qualifications & \\
\hline $\begin{array}{l}\text { Experience in Youth } \\
\text { Development }\end{array}$ & \\
\hline Tel / Cell: & \\
\hline Email & \\
\hline
\end{tabular}

\section{SECTION B: SOCIO-ECONOMIC PROFILE}

1. What is the total population estimate of your municipal area?

2. What is your estimated unemployment level?

3. What is the youth population share in your municipality?

4. How is the youth affected by the level of unemployment and poverty?

\section{SECTION C: APPROACH TO YOUTH DEVELOPMENT}

5. How does your municipality define youth and youth development?

6. Does your municipality have an approach and or framework to Youth Development?

7. What are the main areas of focus for youth development in your municipality?

8. Does your municipality have a comprehensive Youth Development Plan or Strategy?

9. Are any of your planning processes for youth development allowing for youth participation? 
10. Does you IDP or LED or any broader municipal development plans, address youth development issues?

\section{SECTION D: EFFECTIVE PERFORMANCE MANAGEMENT SYSTEM}

11. Does your municipality have a performance framework and systems?

12. Arising out of the above, does your municipality have a performance management plan in place?

13. To what extent, are the youth development issues integrated into the performance management plans?

14. Do individual performance management contracts and plans of the MM, and Youth Development Managers, include youth development targets

\section{SECTION E: YOUTH DEVELOPMENT PERFOMANCE MEASURES?}

15. Are there relevant youth development KPA's, identified?

16. Are clearly defined KPI's and targets in place?

17. How are these performance measures derived?

18. Are these measures integrated into the PM plans (i.e. Individual and organisational) for the NDM? 
APPENDIX B: INTERVIEW QUESTIONS FOR THE MANAGER: IDP 


\section{Youth Development Performance Management}

Interview Schedule

For Managers Planning and Development,

\section{SECTION A: PARTICIPANT'S BIOGRAPHY}

\begin{tabular}{|l|l|}
\hline Name of Interviewee: & \\
\hline Organisation & \\
\hline Position Held & \\
\hline Qualifications & \\
\hline $\begin{array}{l}\text { Experience in Youth } \\
\text { Development }\end{array}$ & \\
\hline Tel / Cell: & \\
\hline Email & \\
\hline
\end{tabular}

\section{SECTION B: Questions}

1. What is your understanding of youth and youth development?

2. Towhat extent do your municipalities' IDP process cater for youth development matters?

3. How do your municipalities align and integrate youth development issues with the broad municipal planning?

4. In your IDP, youth development is an issue on its own. Why is this the case? How does is youth development filtered in the broader plans?

5. How do you best ensure the participation of the youth through out the planning, implementation, and reporting stages?

6. Does the municipality have a local IYDS in Place? 
APPENDIX C: INTERVIEW QUESTIONS FOR THE MANAGER: PMS 


\section{Youth Development Performance Management}

Interview Schedule

For Manager: Performance Management

\section{SECTION A: PARTICIPANT'S BIOGRAPHY}

\begin{tabular}{|l|l|}
\hline Name of Interviewee: & \\
\hline Organisation & \\
\hline Position Held & \\
\hline Qualifications & \\
\hline $\begin{array}{l}\text { Experience in Youth } \\
\text { Development }\end{array}$ & \\
\hline Tel / Cell: & \\
\hline Email & \\
\hline
\end{tabular}

\section{SECTION B: Questions}

1. What is your understanding of youth and youth development?

2. Is there a Performance System and Framework currently in place in the NDM?

3. What does the NDM prefer as a performance model, how does it work?

4. Are there performance plans in place, for both organisational and individual plans?

5. Do the performance contracts include youth development issues, for all the seniors including the Municipal Manager, Section 57 managers and the Youth Development Manager?

6. Are there cleary defined prformance measures for youth development in the NDM?

7. Do you involve the youth when determining the key performance measures for youh develomemt? 
APPENDIX D: QUESTIONS FOR THE FOCUS GROUP DISCUSSIONS 


\section{Youth Development Performance Management Interview Schedule}

FOCUSED GROUP DISCUSSIONS

For Civic Society (Local SAYC)

Facilitator

Group Size

1. What is your understanding of Youth Development?

2. What is the best way to define a common and uniform Youth development Agenda?

3. Does the municipalities consult widely enough when developing youth development strategies or plans?

4. Do you think the current performance management system in the municipality does cater for youth development?

5. What are the main KPA's, KPI's and tagerts for youth development in your municipalities?

6. How best can your municipality define and include youth development indicators and targets in the Performance Management Plans?

7. Is there a seamless linkage between the youth development issues and the performance management plans and contacts? 


\title{
Youth Development Performance Management Interview Schedule
}

\author{
FOCUSED GROUP DISCUSSIONS
}

For National Youth Development Experts

Facilitator

Group Size

1. Are there example available where youth development in local government is implemented successfully?

2. How can Youth Development activities be integrated and aligned to municipal planing and budgetting?

3. What could be the best way to mainstream youth development in local government?

4. What needs to be done to fast track the implemenation of the legislative imperatives contained in the National Youth Development Agecy Act, the National Youth Policy and Local Government legislation?

5. Generally, what is the attitude of municipalities towards youth development in South Africa?

6. What is the best way to collect the performance information on youth development, in local government? 